UNIVERSIDADE DE SÃO PAULO

JOSÉ LUIZ PIMENTA JUNIOR

COALIZÕES INTERNACIONAIS E O G-20: ASPECTOS DA LIDERANÇA BRASILEIRA NA RODADA DOHA DE DESENVOLVIMENTO DA OMC 
JOSÉ LUIZ PIMENTA JUNIOR

COALIZÕES INTERNACIONAIS E O G-20: ASPECTOS DA LIDERANÇA BRASILEIRA NA RODADA DOHA DE DESENVOLVIMENTO DA OMC

Dissertação apresentada ao Programa de Pósgraduação em Relações Internacionais do Instituto de Relações Internacionais da Universidade São Paulo, para a obtenção do título de Mestre em Relações Internacionais.

Área de Concentração: Economia Política Internacional. Subárea: Política Comercial e Negociações Internacionais

Orientadora: Profa. Dra. Janina Onuki 
JOSÉ LUIZ PIMENTA JUNIOR

\title{
COALIZÕES INTERNACIONAIS E O G-20: ASPECTOS DA LIDERANÇA BRASILEIRA NA RODADA DOHA DE DESENVOLVIMENTO DA OMC
}

\begin{abstract}
Dissertação apresentada para obtenção do título de Mestre em Relações Internacionais do Instituto de Relações Internacionais da Universidade de São Paulo, na área de concentração Economia Política Internacional, subárea Política Comercial e Negociações Internacionais.
\end{abstract}

BANCA EXAMINADORA

Orientador:

Profa. Dra. Janina Onuki (IRI/USP)

$2^{\circ}$ Examinador:

$3^{\circ}$ Examinador:

$4^{\circ}$ Examinador:

São Paulo, de de 2012 


\section{Agradecimentos}

Agradeço a minha família pelo apoio fundamental dado ao longo desses dois anos e meio de mestrado. Mesmo de longe, meu pai (José Luiz Pimenta) e minha mãe (Sandra Pimenta) foram, e continuam sendo, fonte de inspiração para todos os desafios da minha vida.

Da mesma forma, agradeço a Marília Souza, esposa, amiga e companheira, sempre ao meu lado nas etapas mais importantes da minha vida, e que durante o mestrado se mostrou imprescindível, criticando, corrigindo e auxiliando-me durante toda a elaboração do mesmo.

Meu muito obrigado também à Prof ${ }^{\mathrm{a}} \mathrm{Dr}^{\mathrm{a}}$ Janina Onuki, fundamental em toda a minha carreira acadêmica, desde minha iniciação científica, passando pelos Trabalhos de Conclusão de Curso do Bacharelado e da Pós Graduação, e chegando comigo ao fim do mestrado. Sem suas leituras, críticas, debates e discussões, esse trabalho certamente não teria sido gerado.

Agradeço imensamente ao amigo e irmão, Luiz Vicente Justino Jácomo, pelo enorme auxílio nas leituras e releituras da dissertação, as quais foram essenciais para a conclusão do trabalho.

Por fim, agradeço aos Ministros, Embaixadores e pesquisadores entrevistados pela contribuição qualitativa de altíssimo nível, indispensável na concepção e elaboração da pesquisa como um todo.

São Paulo, 27 de julho de 2012 


\section{RESUMO}

Desde a criação da OMC em 1995, países desenvolvidos e em desenvolvimento intensificaram a busca por uma ação coordenada mais efetiva e, principalmente durante a Rodada Doha, passaram a influenciar o processo de tomada de decisão por meio da criação de coalizões internacionais. A atuação paradigmática do Brasil no processo de formação e atuação do G20 fez com que o país se tornasse um eminente player nas negociações agrícolas da Rodada de Desenvolvimento de Doha e entrasse de maneira definitiva no alto nível decisório da Organização. Dessa forma, o objetivo deste trabalho é explorar o debate relacionado à atuação das coalizões internacionais, bem como identificar os elementos que constituem a liderança política nesse modo de ação coletiva, sobretudo no que se relaciona ao caso da atuação do Brasil no G20 durante as negociações da Rodada Doha da OMC.

Palavras-Chave: OMC, G20, Liderança, Negociações, Agricultura, Rodada Doha. 


\begin{abstract}
Since the creation of the WTO in 1995, developed and developing countries intensified the demand for a more effective and coordinated action, especially during the Doha Round, and began to influence the decision making process through the creation of international coalitions. The paradigmatic role of Brazil in the formation and performance of the G20 has rendered the country a prominent position in the agricultural negotiations of the Doha Development Round. Thus, the objective of this paper is to explore the debate related to the performance of international coalitions, and to identify the elements that constitute the political leadership in this mode of collective action, especially with regard to the case of Brazil's role in G20 during negotiations of the WTO Doha Round.
\end{abstract}

Keywords: WTO, G20, Leadership, Negotiations, Agriculture, Doha Round. 


\section{LISTA DE ABREVIATURAS}

AA: Acordo sobre Agricultura

AMS: Medidas Agregadas de Apoio

ASEAN: Associação de Nações do Sudeste Asiático

BATNA: Best Alternative for a Negotiated Agreement

BCE: Benefícios Coletivos Exclusivos

BCI: Benefícios Coletivos Inclusivos

CEPEA: Centro de Estudos Avançados em Economia Aplicada

FUNCEX: Fundação Centro de Estudos do Comércio Exterior

GATT: Acordo Geral de Tarifas e Comércio

IBGE: Instituto Brasileiro de Geografia e Estatísticas

FIPS: Five Interested Parties

INCRA: Instituto Nacional de Colonização e Reforma Agrária

MERCOSUL: Mercado Comum do Sul

MAPA: Ministério da Agricultura, Pecuária e Abastecimento

MDA: Ministério do Desenvolvimento Agrário

MDIC: Ministério do Desenvolvimento Indústria e Comércio Exterior

MRE: Ministério das Relações Exteriores

NAMA: Acesso a Mercados para Bens não Agrícolas

OMC: Organização Mundial do Comércio

PEDs: Países em desenvolvimento

PDs: Países desenvolvidos

PMDRs: Países de Menor Desenvolvimento Relativo

SAF: Secretaria de Agricultura Familiar

SMC: Sistema Multilateral de Comércio

SSM: Mecanismo de Salvaguardas Especiais

TPA: Trade Promotion Authority

UNCTAD: Convenção das Nações Unidas para Comércio e Desenvolvimento

UNFCCC: Convenção-Quadro das Nações Unidas sobre Mudança do Clima

VTD: Valor Total de Produção 
SUMÁRIO

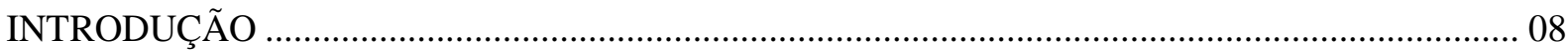

1 COALIZÕES INTERNACIONAIS, AÇÃO COLETIVA E LIDERANÇA POLÍTICA ..................... 10

1.1 O ESTUDO DAS COALIZÕES AO LONGO DO TEMPO …………………………………. 10

1.2 A LÓGICA DA AÇÃO COLETIVA DE MANCUR OLSON E O EMPREENDEDORISMO POLÍTICO DE RUSSEL HARDIN.

1.3 LIDERANÇA POLÍTICA NAS RELAÇÕES INTERNACIONAIS ......................................... 27

2 O G20 E RODADA DOHA DA OMC: LIDERANÇA BRASILEIRA NAS NEGOCIAÇÕES MULTILATERAIS SOBRE O COMÉRCIO AGRÍCOLA …………………………………………... 44

2.1 A REGULAÇÃO DO COMÉRCIO AGRÍCOLA NO ÂMBITO MULTILATERAL ................. 44

2.2 A IMPORTÂNCIA DO TEMA AGRÍCOLA PARA O BRASIL ……………………………..... 52

2.3 ANÁLISE DA ATUAÇÃO DO G20 DURANTE A RODADA DOHA DA OMC..................... 56

2.4 OS PRINCIPAIS ASPECTOS E EFEITOS DA LIDERANÇA DO BRASIL NO G20 ............ 73

2.4.1 APRESENTAÇÃO DOS RESULTADOS …………………………………………..... 76

2.4.1.1 O BRASIL E A FORMAÇÃO DO G20 ..................................................................... 76

2.4.1.2 A ATUAÇÃO DO BRASIL APÓS A FORMAÇÃO DO G20 ……………………....... 79

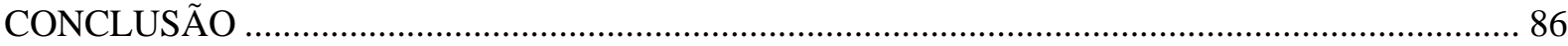

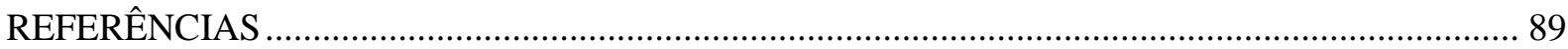




\section{Introdução}

Nas últimas décadas, a crescente complexidade das negociações multilaterais fez com que os países interessados em alcançar seus diversos objetivos passassem a atuar de forma coordenada, por meio da formação de coalizões. Tal fato deu-se, sobretudo, devido à latente interdependência econômica que marcou as últimas décadas do século $\mathrm{XX}$ e a primeira década do século XXI, que fez com que a capacidade dos Estados em realizar seus objetivos de maneira individual fosse restringida.

Desde a criação da OMC em 1995 e a consequente celebração dos acordos multilaterais que passaram a regular o comércio de bens agrícolas, industriais e de serviços, países desenvolvidos (PDs) e em processo de desenvolvimento (PEDs) intensificaram a busca por uma ação coordenada mais efetiva e, principalmente durante a Rodada Doha de Desenvolvimento, passaram a influenciar o processo de tomada de decisão por meio da criação de coalizões internacionais.

Apesar das diferentes visões ideológicas, interesses intranacionais e projeção no cenário internacional, diversos países, entre eles o Brasil, viram, na ação coletiva, um meio que possibilitaria concretização de seus interesses econômicos e comerciais no âmbito da Organização. A atuação paradigmática do Brasil no processo de formação e atuação do G20, no âmbito da $\mathrm{OMC}$, fez com que o país se tornasse um eminente player nas negociações agrícolas da Rodada de Desenvolvimento de Doha e entrasse de maneira definitiva no alto nível decisório da Organização.

A coalizão, sob a coordenação do Brasil, alterou significativamente o processo de negociação, por meio da superação das diferenças entre os países em desenvolvimento e a formação de uma plataforma de atuação conjunta em um dos temas mais complexos na negociação, a área agrícola.

Dessa forma, o objetivo deste trabalho é explorar o debate relacionado à atuação das coalizões internacionais, bem como identificar os elementos que constituem a liderança política nesse modo de ação coletiva, sobretudo no que se relaciona ao caso da atuação do Brasil no G20 durante as negociações da Rodada Doha da OMC. Em suma, partimos da hipótese de que o Brasil, ao ter se tornado importante interlocutor dos interesses dos PEDs no âmbito da Rodada Doha, liderou a criação do G-20 e manteve essa liderança ao longo da atuação da coalizão durante a Rodada, entre os anos de 2003 e 2008. 
A metodologia empregada para a análise empírica da liderança do Brasil, que terá lugar no último capítulo do presente trabalho, teve como elemento fundamental, além da análise de documentos, pronunciamentos e documentos de posição do Grupo, a realização de quatro entrevistas com negociadores do Ministério das Relações Exteriores e outros observadores que atuaram ativamente durante as negociações agrícolas da Rodada Doha da OMC. Com base nos resultados das entrevistas, observar-se-á a existência de traços de liderança por parte do Brasil no âmbito do grupo, sobretudo por meio da análise de quatro variáveis independentes. É necessário destacar que todas as variáveis do estudo (dependentes e independentes) foram devidamente definidas no último capítulo do presente trabalho.

Optou-se por fazer entrevistas com atores-chave do processo de negociação da OMC e que participaram como representantes do Brasil no G20. A preocupação, portanto, não foi aplicar uma quantidade extensa de questionários para captar uma determinada percepção, mas selecionar os atores que seriam entrevistados a partir do seu conhecimento específico sobre o tema, para os quais foi preparado um roteiro de entrevista semiestruturado.

Com base na complementaridade obtida entre as entrevistas realizadas e as variáveis expostas, buscar-se-á analisar a liderança do Brasil de maneira integrada, levando-se em consideração as diversas particularidades da negociação, como os interesses negociadores e as assimetrias entre os membros. Dessa forma, a presente pesquisa visa a contribuir para a pesquisa no campo de estudo da liderança política internacional, com base em uma metodologia de análise que alia os aspectos teóricos empregados na observação do fenômeno à percepção de atores e observadores privilegiados no processo negociador.

No primeiro capítulo serão apresentados diversos elementos teóricos relacionados à formação e à atuação das coalizões. Os desafios e os custos empregados na ação coletiva serão abordados de maneira concisa e objetiva. Além disso, a parte final do capítulo abordará os principais aspectos teóricos da liderança política internacional. O papel do líder, suas estratégias, restrições, entre outros, serão expostos nessa seção.

O segundo capítulo está dividido em quatro partes. Primeiramente, o texto expõe as principais determinantes da regulação do comércio agrícola em nível multilateral. Em seguida, serão destacados os dois elementos da agricultura nacional que justificam o engajamento do Brasil nas negociações no âmbito multilateral. Por fim, após a análise da atuação do G20 durante a Rodada Doha da OMC, destacaremos, na última seção do capítulo, os resultados da análise empírica da liderança do Brasil no âmbito do G20 agrícola da OMC. 


\section{Coalizões Internacionais, Ação Coletiva e Liderança Política}

O presente capítulo visa a apresentar os principais aspectos teóricos relacionados à dinâmica de formação e atuação das coalizões ao logo do tempo. Da mesma forma, expõe as principais vertentes relacionadas ao estudo do fenômeno da liderança política internacional.

\subsection{O estudo das coalizões ao longo do tempo}

O estudo específico das teorias sobre coalizões fundou-se, preliminarmente, na análise sobre a formação de governos em sistemas parlamentares, sendo depois ampliado e reconfigurado para proporcionar um aporte teórico-explicativo sobre os estudos de agrupamentos políticos em nível mundial. ${ }^{1}$ As alterações substanciais ocorridas nesse campo de estudo ocorreram por meio da criação e aperfeiçoamento de conceitos e metodologias de análise que tiveram início, sobretudo, a partir da década de 1960, e que influenciaram significativamente a maneira de se analisar o fenômeno da ação coletiva ao longo do tempo.

Àquela época, o "princípio do tamanho das coalizões" ou size principle, exposto na obra The Theory of Political Coalition, de Willian Riker, foi exemplo de como o rigor metodológico e critérios de formalização passaram a ser aplicados ao estudo das Ciências Sociais. Nessa obra, que se insere em um debate sobre ação coletiva com outro autor de sua época (o americano Anthony Downs), Riker busca afirmar, ao contrário da teoria de maximização de votos proposta por Downs, que nenhuma coalizão seria intencionalmente maior do que ela realmente precisaria ser, no intuito de assegurar que seus objetivos conjuntos fossem colocados em prática ${ }^{2}$. Segundo Riker:

Downs assumed that political parties (a kind of coalition) seek to maximize votes (membership). As against this, I shall attempt to show that they seek to maximize only up to the point of subjective certainty of winning. After that point, they seek to minimize, that is, to maintain themselves at the size (as subjectively estimated) of a minimum winning coalition ${ }^{3}$.

\footnotetext{
${ }^{1}$ Uma análise sistemática de todo o processo de evolução referente às Teorias de Coalizão, sobretudo no que se refere à revisão bibliográfica do tema, encontra-se em: OLIVEIRA, Amâncio J., ONUKI, Janina e OLIVEIRA, Emmanuel. Coalizões Sul-Sul e multilateralismo: Índia, Brasil e África do Sul. In: OLIVEIRA; Amâncio J., ONUKI, Janina, Coalizões Sul-Sul e as negociações multilaterais: os países intermediários e a coalizão IBSA. São Paulo: Mídia Alternativa Comunicação e Editora, 2007.

2 WEALE, Albert. Social Choice versus Populism? An interpretation of Riker's Political Theory. British Journal of Political Science, Cambridge, Reino Unido, Cambridge University Press Vol. 14, no 3, 1984, p. 374.

${ }^{3}$ RIKER, William H. The Theory of Political Coalitions. New Heaven, Yale University Press, 1962, p. 33.
} 
A partir de então, Riker buscou delimitar, com base na metodologia relacionada à Teoria dos Jogos, o conjunto de premissas em que sua hipótese seria alicerçada. Dessa forma, segundo o autor "em jogos de n-pessoas, de soma zero, em que benefícios (syde payments) sejam permitidos, em que os jogadores sejam racionais e dotados de informação perfeitas, somente coalizões mínimas ocorrem" . Como para Riker a maximização dos votos por parte de uma coalizão é altamente custosa, jogadores (políticos, por exemplo), ao formarem coalizões vencedoras mínimas, além de fazerem o mínimo de concessões possíveis, conseguem promover a manutenção do suporte necessário para manter sua autoridade e atingir seus objetivos (aprovar uma legislação, por exemplo) ${ }^{5}$.

Apesar de amplamente reconhecido como pilar fundamental de uma Teoria que transformou o estudo da Ciência Política em sua época, o princípio do tamanho das coalizões sofreu críticas, sobretudo por conta de sua rigidez conceitual. Autores como Russel Hardin ${ }^{6}$ mostraram que, se alguma das premissas expostas por Riker no jogo for retirada, as coalizões poderiam ter incentivos para formar agrupamentos maiores do que seu tamanho mínimo. Outros, como Bruce Russett, afirmavam que modelo proposto por Riker não pressupunha a diversidade da configuração de poder característica ao interior da coalizão. De acordo com o Russet:

While the theory [of Riker] rests upon an impressive piece of deductive reasoning, and some bits of empirical evidence as well, its limitations are severe [...] Most historical international systems of much interest, even those which are to a large degree bipolar, have had several middle-level states whose adherence to one side or another exerted significant effects on the distribution of power in the system. ${ }^{7}$

Para Russet, o foco desse tipo de pesquisa deveria estar nas condições em que o princípio do tamanho das coalizões torna-se operacional, uma vez que, segundo ele, algumas variáveis como (a) falta de informação, (b) custos relacionados ao processo de barganha, e (c) tamanho dos payoffs podem alterar a relação custo-benefício implícita na formação de

\footnotetext{
${ }^{4}$ RIKER, William H. The Theory of Political Coalitions. New Heaven, Yale University Press, 1962, p. 32. (Tradução do autor)

${ }^{5}$ SHEPSLE, Kenneth; BUENO DE MESQUITA, Bruce. Willian Harrison Riker (1920-1993) - Biographical Memoirs, Washington D.C, EUA, The National Academy Press, 2001, p. 9.

${ }^{6}$ HARDIN, Russel, Hollow Victory: The Minimum Winning Coalition, American Political Science Review, LXX 1976, 1202-1214 apud WEALE, Albert. Social Choice versus Populism? An interpretation of Riker's Political Theory. British Journal of Political Science, Cambridge, Reino Unido, Cambridge University Press Vol. 14, $n^{\circ} 3,1984$, p. 376.

${ }^{7}$ RUSSETT, Bruce M. Components of an Operational Theory of International Alliance Formation. The Journal of Conflict Resolution. Vol. 12, nº 3, Set. 1968, p. 286
} 
coalizões vencedoras mínimas ${ }^{8}$. A partir dessas constatações, Russet apresenta componentes importantes para o estudo da formação de alianças, tais como: o peso político e econômico dos países, a distribuição dos side-payments intra coalizão, o contexto político para a formação de coalizões (guerra ou paz), entre outros.

Durante a década de 1960, as premissas teóricas de Riker também foram revistas e ampliadas pelo cientista social americano William Gamson. Este afirmava que os atores de uma determinada coalizão também se pautavam por afinidades político-ideológicas na formação da mesma, definidas por ele como preferências não utilitárias ${ }^{9}$. Gamson parte da hipótese de que "qualquer participante [de uma coalizão] irá esperar que os outros [participantes] demandem dessa coalizão uma parcela do pay off proporcional à quantia de recursos com que ele contribuiu para a formação da mesma"10.

Por conta disso, os atores da coalizão buscam maximizar seus ganhos em relação à contribuição de recursos, almejando formar, assim como Riker também afirmava, coalizões vencedoras mínimas (cheapest winning coalitions), composta somente por membros que tenham os recursos necessários para que o grupo chegue ao chamado ponto de decisão

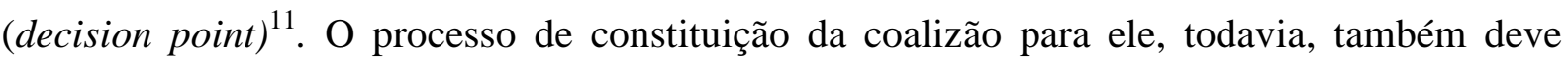
levar em consideração, além do cálculo do retorno da contribuição dos recursos, preferências estratégicas não utilitárias.

The sources of this non-utilitary preferences will vary depending on the situation: in a small committee, the primary source would probably be interpersonal attraction. In a political convention, we would expect the relative similarity of other's ideology and beliefs to be the principal determinant ${ }^{12}$.

Outro eminente autor que contribuiu para o debate sobre a formação de coalizões foi Theodore Caplow, que durante essa mesma época expunha a necessidade de se analisar, no âmbito da formação de determinados grupos, o "equilíbrio de poder intracoalizão", já que, segundo ele, os atores elaborariam estratégias com o intuito de controlar os demais membros

\footnotetext{
${ }^{8}$ RUSSETT, Bruce M. Components of an Operational Theory of International Alliance Formation. The Journal of Conflict Resolution. Vol. 12, n 3, Set. 1968, p. 292

9 OLIVEIRA, Amâncio J., ONUKI, Janina e OLIVEIRA, Emmanuel. Coalizões Sul-Sul e multilateralismo: Índia, Brasil e África do Sul. In: OLIVEIRA; Amâncio J., ONUKI, Janina, Coalizões Sul-Sul e as negociações multilaterais: os países intermediários e a coalizão IBSA. São Paulo: Mídia Alternativa Comunicação e Editora, 2007, p. 24.

${ }^{10}$ GAMSON, William A. A Theory of Coalition Formation. American Sociological Review, Vol. 26, $\mathrm{n}^{\mathrm{o}}$ 3, Jun. 1961 , p. 376.

${ }^{11}$ Em linhas gerais, o chamado decision point é a proporção mínima de recursos necessários para o controle da decisão. Para mais detalhes ver: GAMSON, Willian A. Op. cit. p. 374.

${ }^{12}$ Idem, p. 375.
} 
do grupo, por exemplo ${ }^{13}$. Caplow rechaçava a ideia, implícita em algumas teorias e modelos da época, de que como havia igualdade de poder entre os atores da coalizão, compensações (side payments) era a forma encontrada por determinados atores para angariar potenciais membros para uma coalizão. Segundo Caplow:

This assumption [equality of power] does not fit many triads of sociological interest in which the typical gain consists of domination over other triad members, and not in an external reward to be obtained by a given coalition ${ }^{14}$.

Dessa forma, dentre as principais premissas estabelecidas no modelo do autor, estão as de que (a) os membros de um grupo diferem em termos de poder, sendo que o membro mais forte pode e busca controlar o mais fraco; e (b) cada membro da coalizão busca o controle sobre outros e, com isso, em um grupo de três, o controle de um ator sobre os dois outros é preferível ao controle de apenas um ator sobre o outro. ${ }^{15}$ A partir disso, segundo Caplow, há uma grande possibilidade de que, em determinadas situações, atores menos poderosos do que outros formem coalizões para exercer o controle, em uma determinada situação, sobre o ator individualmente mais poderoso (Ex: situação em que $A>B ; B=C$; porém $A<(B+C))^{16}$

Bárbara Hincley, em 1979, por sua vez, contribuiu para expandir a natureza do tema e proporcionar uma perspectiva de análise que poderia ser transposta para o campo internacional onde crescentemente operavam diversas coalizões. Assim, a abordagem de Hincley foi marcada à época pela ampliação da perspectiva analítica das coalizões que, em sua maioria, era pautada pelo estudo das aplicações empíricas do princípio do "tamanho das coalizões” elaborado por Riker em 1962.

Com isso, a autora atenta para a necessidade da ampliação do escopo analítico sobre o tema e atesta que uma nova vertente teórica, baseada na pesquisa sócio-psicológica sobre coalizões, merece ser considerada. Segundo Hincley, essa vertente não era, à época, familiar aos cientistas políticos, pois não possuía inspiração na teoria dos jogos e não era focada em como os atores deveriam formar coalizões, mas sim na maneira como eles realmente

\footnotetext{
${ }^{13}$ OLIVEIRA, Amâncio J., ONUKI, Janina e OLIVEIRA, Emmanuel. Coalizões Sul-Sul e multilateralismo: Índia, Brasil e África do Sul. In: OLIVEIRA; Amâncio J., ONUKI, Janina, Coalizões Sul-Sul e as negociações multilaterais: os países intermediários e a coalizão IBSA. São Paulo: Mídia Alternativa Comunicação e Editora, 2007, p. 25.

${ }^{14}$ CAPLOW, Theodore. A Theory of Coalitions in the Triad. American Sociological Review, Vol. 21, $\mathrm{n}^{\mathrm{o}} 4$, Ago. 1956, p. 489.

${ }^{15}$ Idem, p.489.

${ }^{16}$ Idem, p. 490
} 
formavam esses agrupamentos e como as condições gerais (externas e internas ao grupo) facilitavam ou inibiam distintos resultados. ${ }^{17}$

Preocupada, sobretudo, em analisar o comportamento das coalizões por meio de uma perspectiva política, caracterizada por três fatores essenciais (uso de recursos para alcançar um determinado resultado; atividade coletiva e um ambiente que combinasse conflito e cooperação - mixed motive situation), a autora apresenta, com base em uma ampla revisão bibliográfica, vinte e uma variáveis-chave essenciais para um estudo mais abrangente da formação e atuação das coalizões (cf. Quadro 1). De acordo com Hincley, as relações entre essas variáveis devem ser abertas e sua fixação como sendo dependentes (respostas) ou independentes (explicativas) deverá variar entre as pesquisas. Em sua análise, contudo, a autora estabelece o grupo 4 como variável dependente dos outros três grupos, ou seja, em uma determinada situação política, ela analisa como os fatores (atributos dos atores, distribuição inicial dos recursos e condições e regras do jogo) influenciaram o resultado final (comportamento) das coalizões, que, segundo ela podem ser compostas de indivíduos ou coletividades (países no âmbito multilateral, por exemplo.) ${ }^{18}$

Quadro 1 - Vinte e uma variáveis para o estudo do comportamento das coalizões divididas entre grupos

\begin{tabular}{|c|c|c|c|}
\hline $\begin{array}{c}\text { Grupo } 1 \\
\text { Atributos dos atores }\end{array}$ & $\begin{array}{c}\text { Grupo } 2 \\
\text { Distribuição inicial dos } \\
\text { recursos }\end{array}$ & $\begin{array}{c}\text { Grupo } 3 \\
\text { Condições e } \\
\text { Regras do Jogo }\end{array}$ & $\begin{array}{c}\text { Grupo } 4 \\
\text { Resultados } \\
\text { (Comportamentos) das } \\
\text { Coalizões } \\
\end{array}$ \\
\hline $\begin{array}{l}\text { Semelhança ou diferença } \\
\text { entre os atores }\end{array}$ & Variação nos recursos iniciais & Dimensão da participação & $\begin{array}{c}\text { Escolha do parceiro } \\
\text { (tipo de coalizão formada) }\end{array}$ \\
\hline $\begin{array}{c}\text { Diferenciação do status } \\
\text { dos atores }\end{array}$ & $\begin{array}{c}\text { Amplitude da vantagem } \\
\text { de um determinado jogador }\end{array}$ & Recorrência do jogo & $\begin{array}{l}\text { Atividade da coalizão: } \\
\text { formação de algumas ou de } \\
\text { nenhuma coalizão }\end{array}$ \\
\hline $\begin{array}{c}\text { Sobreposição do papel } \\
\text { dos atores em diferentes } \\
\text { coalizões }\end{array}$ & $\begin{array}{l}\text { Probabilidade futura } \\
\text { de sucesso }\end{array}$ & $\begin{array}{l}\text { Barganha impessoal } \\
\text { ou "cara a cara" }\end{array}$ & $\begin{array}{l}\text { Estabilidade da coalizão } \\
\text { ao longo do tempo }\end{array}$ \\
\hline $\begin{array}{c}\text { Atitude em relação à } \\
\text { vitória ou à competição }\end{array}$ & & $\begin{array}{l}\text { Barganha fechada } \\
\text { ou aberta }\end{array}$ & $\begin{array}{l}\text { Tendência na formação de } \\
\text { coalizões conservadoras ou } \\
\text { revolucionáias }\end{array}$ \\
\hline Experiência com o jogo & & $\begin{array}{c}\text { Facilitação na comunicação } \\
\text { com outros jogadores }\end{array}$ & $\begin{array}{l}\text { Inclusão ou não do jogador } \\
\text { mais forte na coalizão } \\
\text { vencedora }\end{array}$ \\
\hline $\begin{array}{c}\text { Experiência com outros } \\
\text { jogadores }\end{array}$ & & $\begin{array}{l}\text { Clareza ou confusão na } \\
\text { situação de barganha }\end{array}$ & $\begin{array}{l}\text { Distribuição dos ganhos } \\
\text { (payoffs) }\end{array}$ \\
\hline
\end{tabular}

Fonte: HINCKLEY, Barbara. Twenty-one Variables Beyond the Size of Winning Coalitions. The Journal of Politics, Vol. 41, no 41, Fev. 1979, p. 194. p.199.

\footnotetext{
${ }^{17}$ HINCKLEY, Barbara. Twenty-one Variables Beyond the Size of Winning Coalitions. The Journal of Politics, Vol. 41, no 41, Fev. 1979, p. 194.

${ }^{18}$ Idem, p.199.
} 
Em que pese a heterogeneidade das interpretações e análises teóricas sobre o tema, de acordo com a exposição dos autores até aqui citados percebe-se que a discussão referente à formação e ao comportamento das coalizões contou, a partir de meados do século XX, com importantes contribuições conceituais e metodológicas.

No que se refere ao cenário internacional, com o incremento do processo negociador em arenas multilaterais, sobretudo a partir da década de 1970, as nações passaram a formular estratégias de participação conjunta em diversos fóruns com o intuito de alcançarem seus objetivos com mais eficiência. A formação de agrupamentos, seja estimulada por afinidades ideológicas ou por objetivos específicos, fez com que diversas entidades, como a OMC, foco desse estudo; a Convenção das Nações Unidas para Comércio e Desenvolvimento UNCTAD; a Convenção-Quadro das Nações Unidas sobre Mudança do Clima - UNFCCC, entre outras, se tornassem palco para a criação e atuação das coalizões.

Dessa forma, as negociações internacionais se tornaram, gradualmente, um campo fértil para a formação e ação de agrupamentos que, consequentemente, passaram a ser analisados pelas mais diversas vertentes teóricas. De acordo com Oliveira A., Onuki e Oliveira, E:

\begin{abstract}
A motivação dos países em optar por atuar, no jogo das negociações multilaterais, por meio de coalizões internacionais comporta explicações de diferentes matizes teóricas. Possui um amplo espectro que vai desde uma abordagem organizacional, relacionada à diminuição de custos transacionais, principalmente para países de menor desenvolvimento relativo; passa pela análise cognitiva; pela análise neoinstitucionalista, com foco no papel dos grupos de interesse e instituições; pela análise neorrealista, relacionadas à dimensão do equilíbrio de poder, até vertentes construtivistas, calcadas nas dimensões da realidade intersubjetiva, sociabilização e identidade como elementos-chave na constituição de coalizões ${ }^{19}$.
\end{abstract}

Em uma tentativa de tipificar as coalizões existentes no ambiente multilateral, esses autores inferem que os arranjos coalizacionais em sua essência possuem, em geral, motivações de formação endógenas ou exógenas e caráter defensivo ou ofensivo no campo de atuação. Segundo os autores, esses dois elementos combinados originam quatro tipos básicos de coalizões: (a) Exógeno-ofensivas, que incumbe a necessidade de mobilização maciça dos agentes em face de um objetivo definido e convergente para que ocorra o sucesso do que se pleiteia; (b) Exógeno defensivas, que se assemelha à teoria das alianças, não havendo a

${ }^{19}$ OLIVEIRA, Amâncio J., ONUKI, Janina e OLIVEIRA, Emmanuel. Coalizões Sul-Sul e multilateralismo: Índia, Brasil e África do Sul. In: OLIVEIRA; Amâncio J., ONUKI, Janina, Coalizões Sul-Sul e as negociações multilaterais: os países intermediários e a coalizão IBSA. São Paulo: Mídia Alternativa Comunicação e Editora, 2007, p. 30. 
necessidade de "convergência de posicionamento extra-ação coletiva" e tendo como "elemento unificador uma contrariedade ao tópico comum"; (c) Endógeno-ofensivas, que deve ser estruturada por um alto nível de interdependência entre seus membros, além de haver altas demanda por cooperação e, por fim, (d) Endógeno-defensivas, na qual também é imprescindível se ter altos níveis de interdependência. ${ }^{20}$

Os autores afirmam, todavia, que, de maneira ampla, a literatura relacionada a coalizões no âmbito das negociações multilaterais internacionais preocupa-se principalmente em analisar os tipos de coalizões existentes e o padrão de seu comportamento.

Em relação aos tipos de coalizão, os autores explicam que três fatores de análise são os mais recorrentes entre os autores: abrangência (coalizões específicas, que podem ser tanto temáticas quanto abrangentes); padrão de estratégias (coalizões de veto, demandantes ou mediadoras) e origem (regionais, por exemplo). No que diz respeito ao comportamento das coalizões, os estudos, em sua maioria, referem-se à estabilidade, estratégia e eficácia dos agrupamentos.

A despeito da ampla gama de correntes teóricas já mencionadas, no que se refere ao mapeamento das diferentes metodologias existentes bem como à elaboração de importantes conceitos e critérios analíticos, referentes à atuação das coalizões; as contribuições de dois autores tornam-se fundamentais.

O autor neorrealista Christophe Dupont, ao definir coalizões como "cooperative efforts for the attainmment of short-range, issue-specific objectives" ${ }^{, 21}$, faz questão de diferenciar categoricamente uma coalizão de uma aliança formal (esforço cooperativo no qual os direitos e deveres de cada membro são codificados em um tratado); de alinhamentos informais (ideia que gira em torno da expectativa de cooperação que uma nação pode ter em relação a outras nações); e, por fim, de alinhamentos comportamentais (coordenação de comportamentos de um grupo para atuar de uma maneira similar, visando a um objetivo comum).

\footnotetext{
${ }^{20}$ OLIVEIRA, Amâncio J., ONUKI, Janina e OLIVEIRA, Emmanuel. Coalizões Sul-Sul e multilateralismo: Índia, Brasil e África do Sul. In: OLIVEIRA; Amâncio J., ONUKI, Janina, Coalizões Sul-Sul e as negociações multilaterais: os países intermediários e a coalizão IBSA. São Paulo: Mídia Alternativa Comunicação e Editora, 2007, p. 40

${ }^{21}$ DUPONT, Christophe (1994). Coalition Theory: using power to build cooperation. In: ZARTMAN, Willian (org.): International Multilateral Negotiation, part II, cap. 7, p. 148.
} 
O autor afirma que, de uma perspectiva organizacional, para ser considerada uma coalizão, a composição deve atender às seguintes características: (a) o grupo deve interagir entre si; (b) deve ser deliberadamente construído e existir independentemente de uma estrutura formal; (c) não deve acabar mesmo que haja a falta de um objetivo externo (componente ideológico) e, por fim, (d) deve ter uma ação concertada de seus membros. ${ }^{22}$

Preocupado, sobretudo, em analisar os arranjos dos países sob a ótica do equilíbrio de poder, Dupont faz referência a três categorias de análises que seriam necessárias para um entendimento mais completo do estudo das coalizões. A primeira diz respeito à formação do grupo. A segunda refere-se à estabilidade ou duração do mesmo, enquanto que a terceira atribui importância ao impacto dos resultados que as ações das coalizões poderiam ter nas negociações internacionais. Em face desses três níveis de análise, é importante destacar que a formação e a ação coalizacional, segundo o autor, estão diretamente relacionadas à capacidade de sinergia e congruência das aspirações, objetivos e propósitos dos seus membros ${ }^{23}$.

Em relação à eficiência das ações do grupo nas arenas multilaterais, alguns fatores endógenos e exógenos à formação do mesmo são fundamentais. O tamanho das coalizões bem como a existência de um relacionamento institucional prévio entre elas podem interferir no desempenho das mesmas antes e durante a rodada negociadora. Outros fatores, como o grau de simetria das informações disponíveis, as diferentes "constituencies" e a variável tempo, todos exógenos aos arranjos coalizacionais porém intrínsecos ao processo intrainstitucional, interferem diretamente no desempenho dos países. ${ }^{24}$

Especificamente em relação à tipologia de coalizões dentro da OMC, organização mais importante em termos de formação e atuação desses arranjos ao longo do tempo, a autora de vertente construtivista, Amrita Narlikar, destaca que os métodos para a formação de uma coalizão na instituição se baseiam em pressupostos de três correntes teóricas: a Racionalista, a Neoliberal e a Construtivista. Além disso, a autora define coalizão como "any

\footnotetext{
${ }^{22}$ DUPONT, Christophe (1994). Coalition Theory: using power to build cooperation. In: ZARTMAN, Willian (org.): International Multilateral Negotiation, part II, cap. 7, p. 148.

${ }^{23}$ Idem, p. 152 .

${ }^{24}$ Idem, p. 176
} 
group of decision-makers participating in [...] a negotiation and who agree to act in concert to achieve a common end" 25

A vertente racionalista engloba aspectos de outras três vertentes teóricas: (a) as Teorias Formais de Coalizão, as quais tendem a dar importância para a viabilidade e eficiência de um agrupamento, além da operacionalidade do trade-off entre um grande número de atores; (b) as Teorias de Política Econômica Doméstica, que entendem a negociação no comércio internacional como um jogo de dois níveis resultante das pressões da barganha doméstica e do cenário internacional, dinâmica que influencia diretamente as posições e estratégias internacionalmente adotadas pelo Estado e (c) as Teorias que derivam de uma análise Realista das Relações Internacionais, as quais enxergam os interesses dos atores como determinantes fundamentais para a lealdade intracoalizão, porém também atestam que a existência de fatores como anarquia, ganhos relativos, equilíbrio de poder, entre outros; podem comprometer a estabilidade da coalizão, uma vez que, no ambiente institucional, não haveria a existência de "amigos permanentes e sim interesses permanentes". ${ }^{26}$

As coalizões que derivam de pressupostos neoliberais "são aquelas que enfatizam os processos e as instituições, sendo conscientemente criadas por meio da alteração de estratégias, manutenção dos padrões de payoff e side payments", além de basearem a cooperação na reciprocidade intracoalizão. ${ }^{27}$

Por fim, tem-se a vertente construtivista, que transpassaria os conceitos racionalistas na formação de coalizões. Os interesses estatais seriam fruto da interação e do compartilhamento de ideias entre os Estados. Para essa vertente, da qual Narlikar é uma expoente, a formação de uma identidade coletiva e de uma agenda internacional devem ser os produtos finais de uma coalizão, a qual deve buscar como fator predominante de sua coesão interna elementos de solidariedade ${ }^{28}$.

A autora indiana destaca quatro tipos principais de coalizão existente nas rodadas de negociação da OMC: (a) Aliança; (b) Bloco, (c) Combinação ou Sociabilização e (d) Regionalista.

\footnotetext{
${ }^{25}$ NARLIKAR, Amrita. International Trade and Developing Countries, p. 29 apud Colleen HAMILTON e John WHALLEY, Coalitions in the Uruguay Round, Weltwirtschaftliches Archiv., v. 125, n.3, p. 547-556, 1989.

${ }^{26}$ NARLIKAR, Amrita. International trade and developing countries: Bargaining coalitions in the GATT \&WTO. London: Routledge 2003. p. 18-22.

${ }^{27}$ Idem, p 24-26.

${ }^{28}$ Idem, p.27-29.
} 
A coalizão do tipo Aliança, segundo a autora, agrega, em sua estrutura, elementos de teorias Racionalistas, haja vista que tais agrupamentos dependem da definição de um elemento específico para qual a ação de todos deve convergir (issued based). Em virtude disso, tem-se um ambiente no qual está presente o poder, a flexibilidade na agenda e o foco no interesse em última instância. Dessa forma, não importa se os países são alinhados política ou ideologicamente extracoalizão, contanto que trabalhem juntos em busca do objetivo final (que também é o objetivo individual de cada membro) do agrupamento.

A estabilidade desse tipo de agremiação depende da satisfação desses interesses e as razões de aproximação de seus membros são majoritariamente instrumentais. No que concerne à duração deste tipo de coalizão, pode-se inferir que ela está intrinsecamente ligada a sua causa original de criação, ou seja, uma vez cumprido o objetivo, ela está fadada a acabar ou pelo menos a diminuir seu grau de atuação dentro da organização ${ }^{29}$. A coalizão Café au Lait, de grande sucesso na década de 80 dentro do General Agreement on Tarifs and Trade (GATT), é um exemplo desse tipo de coalizão.

A formação em Bloco, em contrapartida, apresenta diversos fatores de formação e manutenção relacionados a elementos característicos da Teoria Construtivista das Relações Internacionais. Tal fato decorre das similaridades político-ideológicas de seus membros já no período de formação do Bloco. O compartilhamento de ideias e de identidades permite reconhecer o aliado, gerando um tipo de perfil chamado "like-minded", ou seja, Estados ideologicamente conectados. Tal formação não necessita de um objetivo especifico, pois geralmente os estados agem em torno de um ideal que se reflete em uma consistente negociação "bloc-based".

Talvez seja essa a razão para a maior durabilidade desses agrupamentos, uma vez que, por apresentarem um ideal ou identidade comum, que dê coesão à estrutura coalizacional, eles estão mais aptos a lidarem com o surgimento de novas questões independentemente do grau de resolução de outras. Geralmente, esse tipo de coalizão ocorre em países que partilham os mesmos problemas econômicos e sociais, como por exemplo, o G-10, do qual o Brasil fazia parte, que se destacou dentro da OMC na década de 80, em face das negociações gerais

\footnotetext{
${ }^{29}$ NARLIKAR, Amrita. International trade and developing countries: Bargaining coalitions in the GATT \&WTO. London: Routledge 2003. p. 31-32.
} 
referentes ao Acordo de Serviços. O grupo representou uma resposta à, até então, fraca participação dos PEDs nas negociações mais relevantes dessa Organização ${ }^{30}$.

Segundo a autora, as coalizões do tipo Combinação ou Sociabilização recebem esse nome já que, literalmente, combinam tanto fatores referentes às Alianças quanto aos Blocos. São coalizões que têm um foco de atuação (issued-based), porém que apresentam, em sentido amplo, uma ligação ideológica. Existem elementos de reciprocidade e de similaridades de interesse, contudo os padrões e os meios de atuação são consistentemente definidos e a estrutura de atuação de tal coalizão foca-se em uma questão por vez (Bloc-type issued-based aproach), fato, porém, que não impede sua atuação em outro setor, uma vez que o assunto original tiver sido resolvido. De acordo com Narlikar, o G20, formado em 2003, no âmbito da OMC, é uma coalizão baseada na sociabilização. ${ }^{31}$

O último tipo de coalizão que a autora analisa é a que tem suas origens no Regionalismo e o utilizam como facilitador de barganhas nas negociações. São as chamadas "Coalizões Naturais", pois seus membros se apoiam em fatores históricos, elementos geográficos e instituições regionais compartilhadas que catalisam a cooperação entre os aliados regionais. Contudo, a ação cooperativa ocorre somente no momento em que houver, efetivamente, convergência de interesses particulares que passam a ser regionais. A partir de então, os aliados regionais operam por meio de uma "plataforma de barganha". Exemplos clássicos dessas formações são o Mercado Comum do Sul (MERCOSUL) criado em 1991 e a Associação de Nações do Sudeste Asiático (ASEAN) criada em $1967 .^{32}$

Especificamente no âmbito do Sistema Multilateral de Comércio (SMC), que teve sua origem no GATT e depois aperfeiçoado com a criação da OMC, as rodadas de negociação sobre novas regras comerciais (tarifárias e não tarifárias) foram marcadas, sobretudo a partir da década de 1960, pela dicotomia de interesses entre PEDs e PDs, fato que abriu espaço para a defesa de diversos interesses e, consequentemente, para a criação de coalizões. Tanto essas dicotomias quanto a congruência de interesses em pólos distintos, entretanto, serão objetos de estudos em momento posterior.

Por hora, é importante ter em consideração que, analisadas tanto em seu aspecto originário quanto operacional, a formação e manutenção de coalizões interestatais engendram

\footnotetext{
${ }^{30}$ NARLIKAR, Amrita. International trade and developing countries : Bargaining coalitions in the GATT \&WTO. London: Routledge 2003. p. 31-32.

${ }^{31}$ NARLIKAR, Amrita. 2003, op, cit. cap. 5.

${ }^{32}$ Idem, Cap. 7.
} 
fatores que se tornaram complexos objetos de análise e sobre os quais teóricos passaram a se debruçar para responder a indagações relacionadas principalmente ao perfil, à estratégia, à eficiência e aos objetivos das coalizões. A geração de massa crítica analítica sobre o tema, sobretudo em nível internacional, é exemplo do aperfeiçoamento que o fenômeno da ação coletiva sofreu ao longo da segunda metade do século XX.

Como se pretendeu aqui demonstrar, baseado em multiplos conceitos e metodologias; enquanto diversos autores partiam de um campo restrito de observação das coalizões, outros procuraram, gradualmente, ampliar o espectro de análise da atuação desses agrupamentos; o que fez com que a observação da ação coletiva ganhasse amplitude, passando do estudo de players restritos em nível nacional, a Estados que atuam na defesa de seus interesses na esfera internacional, sobretudo multilateral.

\subsection{A lógica da ação coletiva de Mancur Olson e o empreendedorismo político de Russel Hardin}

Uma das análises mais relevantes no campo da Ciência Política sobre a ação coletiva e a formação de grupos de interesse foi a do economista e cientista social norte-americano Mancur Olson. O autor apresentou importantes conceitos que rechaçam a ideia de uma "tendência natural" à formação de grupos, mostrando que a rationale desse processo é, na verdade, fruto de um cálculo utilitário dos atores que pressupõe ganhos maiores (benefício marginal líquido) na cooperação do que na ação individual. ${ }^{33}$

Em sua obra "A Lógica da Ação Coletiva", de 1971, Olson parte da hipótese de que, "a menos que o número de indivíduos de um grupo seja realmente pequeno ou que haja coerção ou algum outro dispositivo especial que faça os indivíduos agirem em interesse próprio, os indivíduos racionais e centrados nos próprios interesses não agirão (voluntariamente) para promover seus interesses comuns ou grupais", sobretudo devido à possível incongruência entre interesses individuais e coletivos dos membros de um grupo. ${ }^{34}$

\footnotetext{
33 OLIVEIRA, Amâncio J., ONUKI, Janina e OLIVEIRA, Emmanuel. Coalizões Sul-Sul e multilateralismo: Índia, Brasil e África do Sul. In: OLIVEIRA; Amâncio J., ONUKI, Janina, Coalizões Sul-Sul e as negociações multilaterais: os países intermediários e a coalizão IBSA. São Paulo: Mídia Alternativa Comunicação e Editora, 2007, p. 31

${ }^{34}$ OLSON, Mancur. A lógica da Ação Coletiva. Os Benefícios Públicos e uma Teoria dos Grupos Sociais. Tradução Fábio Fernandez. São Paulo, EDUSP, 1999, p. 14.
} 
Com isso, a formação do interesse de um grupo, que tende a se traduzir em uma ação para a concretização do mesmo, depende da capacidade de um ator (estado, empresa, indivíduo) compreender que a causa grupal tende a ser mais rentável e benéfica do que uma ação individual em torno de um interesse específico. Nesse sentido, Olson explica que qualquer estudo sistemático sobre associações deve analisar primordialmente o seu propósito, e este seria, fundamentalmente, a promoção de interesses de seus membros. Um ponto importante a ser lembrado é que um grupo associativo tem como premissa fundamental de formação a deliberação dos seus membros, que orientam a sua ação social com base em um acordo racionalmente motivado. ${ }^{35}$

No que se refere à abrangência referente ao "grupo associativo", o autor afirma que o tamanho do arranjo pode variar entre extremos e ganhar a forma de uma organização formal, coalizão ou grupo de pressão, tanto no plano nacional quanto no internacional, o que faz com que o estudo das diversas variáveis de cálculo dos atores para buscarem a ação coletiva coordenada se torne cada vez mais complexo. No entanto, dois fatores são fundamentais para a compreensão das formulações olsonianas sobre a ação coletiva e agrupamentos: (a) a distinção entre benefícios coletivos e benefícios privados e (b) o tamanho do grupo.

No contexto da dinâmica que relaciona interesses a agrupamentos, Olson expõe que a função fundamental de uma organização é prover os seus membros com os benefícios coletivos $^{36}$. Dessa forma, para que um benefício possa ser considerado coletivo, ele deve apresentar duas características básicas: a "partilhabilidade" e a "não-exclusão". A primeira "assevera que a utilização de um benefício não diminui a disponibilidade ou fruição desses benefícios para os outros". Já a segunda indica que "uma vez tendo sido provido o bem, nenhum dos beneficiários potenciais pode ser excluído."37

Olson afirma que há uma razão inversamente proporcional quando se analisa o tamanho do grupo e sua relação com a ação coletiva e o provimento dos benefícios coletivos.

\footnotetext{
${ }^{35}$ OLSON, Mancur. A lógica da Ação Coletiva. Os Benefícios Públicos e uma Teoria dos Grupos Sociais. Tradução Fábio Fernandez. São Paulo, EDUSP, 1999, p.18.

36 "Um beneficio público, coletivo ou comum é aqui definido como qualquer benefício que, se for consumido por qualquer pessoa $\mathrm{Xi}$ em um grupo Xi, Xii, Xn, não pode viavelmente negado aos outros membros desse grupo". Idem. Pág 26.

${ }^{37}$ OLIVEIRA, Amâncio J., ONUKI, Janina e OLIVEIRA, Emmanuel. Coalizões Sul-Sul e multilateralismo: Índia, Brasil e África do Sul. In: OLIVEIRA; Amâncio J., ONUKI, Janina, Coalizões Sul-Sul e as negociações multilaterais: os países intermediários e a coalizão IBSA. São Paulo: Mídia Alternativa Comunicação e Editora, 2007, p. 31. Quando se analisam as regras do comércio internacional, alguns dos princípios estruturais que norteiam as negociações entre os membros OMC apresentam tais características. O "single undertaking" e o princípio da não discriminação, expressão na cláusula de nação mais favorecida, artigo I do GATT, são exemplos disso.
} 
Dessa forma, indica que "quanto maior for o grupo, mais longe ele ficará de atingir o ponto ótimo de obtenção do benefício coletivo e menos provável será que ele aja para obter até mesmo uma quantidade mínima desse benefício. Em síntese, quanto maior for o grupo, menos ele promoverá seus interesses comuns". ${ }^{38}$ Sendo assim, pode-se inferir que o provimento do benefício coletivo não é ótimo "naturalmente", pois além de depender de arranjos, negociações e posições internas para ser provido da melhor forma possível, também tem, segundo o autor, uma relação direta com o tamanho do agrupamento e com a contribuição individual dos atores.

No que se refere ao tamanho do grupo, deve-se, também, salientar a importante diferenciação de dois conceitos explicitados pelo autor que interferem diretamente na dinâmica intracoalizão: os benefícios coletivos inclusivos (BCI) e os exclusivos (BCE):

O benefício coletivo exclusivo é, portanto, um benefício de tal natureza que, ao menos dentro de um grupo determinado, a exclusão não é viável, mas é ao mesmo tempo um benefício que não tem nenhum tipo de partilhabilidade de ganhos, razão pela qual os membros do grupo desejam que os outros possam ser excluídos dele.

No beneficio coletivo inclusivo, a exclusão também é inviável, ao menos dentro de um grupo determinado, mas, não obstante, esse tipo de benefício se caracteriza por, pelo menos, um considerável grau de partilhabilidade de ganhos, e isso explica o fato de que membros adicionais possam desfrutar do benefício acarretando pouca ou nenhuma redução do usufruto do mesmo para os membros antigos do grupo. ${ }^{39}$

Tal distinção sobre os benefícios é fundamental, uma vez que remete diretamente à análise do provimento do bem coletivo para os membros do grupo. Nesse sentido, um grupo tende a se manter contrário à adesão de novos integrantes, se essa adesão representar uma nova partilha do beneficio (por ex.: uma nova empresa que tenta entrar em um determinado setor representa um novo competidor). Em contrapartida, em um grupo de pressão, que visa à implementação de uma nova regra no comércio internacional (por ex.: reduções tarifárias, acesso a novos mercados, fim de determinados subsídios); tal beneficio não se altera devido à entrada de um novo membro, que nesse caso é visto como um colaborador.

Essa configuração, no entanto, pode dar origem ao efeito carona (free-rider), no qual um ator, cuja atuação não altera em nada o grau de possibilidade de obtenção do bem coletivo participa da coalizão, recebe os payoffs da negociação e não dispende, na mesma quantidade

\footnotetext{
${ }^{38}$ OLSON, Mancur. A lógica da Ação Coletiva. Os Benefícios Públicos e uma Teoria dos Grupos Sociais. Tradução Fábio Fernandez. São Paulo, EDUSP, 1999, p. 46.

${ }^{39}$ OLSON, Mancur. 1999, op. cit. p. 50
} 
que outros membros, dos custos de ação coletiva necessários para o provimento dos bens (Ex.: pequenos países agrícolas nas negociações da OMC).

Dessa forma, o aumento desordenado do free-rider effect pode se tornar um problema estrutural ao grupo, pois levaria a um desequilíbrio na manutenção dos custos da ação coletiva, apesar de não alterar o equilíbrio na distribuição. Em outras palavras, uns arcariam mais com o ônus e outros não arcariam, todavia a repartição dos benefícios seria igual para todos, considerando que o benefício fosse inclusivo. Nesse sentido, tal dinâmica poderia pôr fim à coalizão, uma vez que os principais players pudessem se sentir indispostos a investir na ação coletiva.

Isso é factível uma vez que, apesar de o benefício inclusivo ser, de tal natureza, que o ganho que um não-cooperador receber não ocasionar perdas correspondentes àqueles que cooperam $^{40}$, a entrada de um novo participante faz com que o custo se altere e se torne desproporcional ao ganho para os que arcam com o ônus, não confirmando a tendência de que uma coalizão se torne cada vez mais forte à medida que ocorre a entrada de um novo membro. Por isso, a manutenção dos diversos custos de ação coletiva dar-se-ia de maneira mais fácil nas coalizões menores.

Se um grupo se comportará de maneira exclusiva ou inclusiva dependerá, no entanto, da natureza do objetivo que o grupo tem em vista, e não de alguma característica do seu corpo de integrantes. ${ }^{41}$

A manutenção desses custos seria menor nas coalizões com tamanho reduzido não somente pela diminuição do efeito carona, mas também porque a ação coletiva em grandes grupos tende a depender do pagamento de benefícios seletivos ou privados (side payments) aos membros do grupo, para motivá-los a cooperar. Portanto, deve-se destacar que, para Olson, "os custos de organização são uma função crescente do número de indivíduos do grupo", pois "quanto maior for o grupo, maior o número de membros que, por via de regra, terão de ser incluídos no acordo ou organização grupal”. Com isso, há uma diminuição da fração de ganho total grupal e da probabilidade de interação oligopolística, além do consequente aumento nos custos de organização (comunicação, barganha intracoalizão, criação, arregimentação e manutenção da organização grupal formal) ${ }^{42}$.

\footnotetext{
${ }^{40}$ OLSON, Mancur. A lógica da Ação Coletiva. Os Benefícios Públicos e uma Teoria dos Grupos Sociais. Tradução Fábio Fernandez. São Paulo, EDUSP, 1999, p.52.

${ }^{41}$ Idem. p.51.

${ }^{42}$ Idem. p. 59 .
} 
Por fim, é importante salientar que Olson especifica uma tipologia de grupos, na qual se distinguem três tipos básicos de agrupamentos: (a) o Privileged Group, em que benefício coletivo é provido sem que haja um acordo grupal formal ou organização; (b) o Intermediary Group, no qual o provimento do bem coletivo depende da coordenação ou organização tácita do grupo; (c) e, por fim, o Latent group, em que o bem coletivo só será alcançado por meio de side-payments aos membros e os custos de organização são elevados. ${ }^{43}$

Outro importante teórico que avança no tema da ação coletiva e apresenta alguns novos conceitos que buscam ampliar a formação de coalizões e o provimento do bem coletivo foi Russel Hardin, em sua obra Collective Action (1982).

Hardin amplia o horizonte analítico de Olson e expõe novos conceitos que podem servir de impulsionadores para a ação coletiva. Na verdade, sua exposição tem como foco os fatores que servem de incentivo para a ação dos membros de um determinado grupo. O autor mostra que nem todo problema de ação coletiva na vida social ocorre em circunstâncias estáticas, mas que os problemas de ação coletiva são dinâmicos e complexos, envolvendo vários fatores que interagem entre si por meio da interrelação entre diferentes atores. Dessa forma, a afirmação de Olson de que "Larger groups are less likely than smaller ones to succeed in providing themselves a collective benefits" deveria ser revista. ${ }^{44}$

O autor toma como foco de sua análise o Dilema do Prisioneiro ${ }^{45}$ como base para a ação coletiva e o comportamento individual dos atores. Ele também ratifica as duas principais características de um bem coletivo (jointness of supply and impossibility of exclusion) nos moldes de Olson, porém indica três importantes componentes que podem promover a ação coletiva dentro de uma coalizão: (a) empreendedorismo político; (b) incentivos seletivos e (c) comportamento extrarracional.

Pelo fato de o conceito de pagamentos seletivos ter sido apresentado no tópico anterior e pelo comportamento extrarracional ser um fator que não tem como pressuposto a ação voluntária dos atores de um grupo, ganha relevância o conceito de empreendedor político e sua relação com a manutenção da ação coletiva.

Through political entrepreneurship, groups may obtain collective benefits despite latency and even despite failure to organize at all. Political

\footnotetext{
${ }^{43}$ OLSON, Mancur. A lógica da Ação Coletiva. Os Benefícios Públicos e uma Teoria dos Grupos Sociais. Tradução Fábio Fernandez. São Paulo, EDUSP, 1999, p.60.

${ }^{44}$ HARDIN, Russel. Collective Action. Baltimore, 1982, The John Hopkins University Press, p.12-13

${ }^{45}$ Idem, p. 2
} 
entrepreneurs are people who, for their own career reasons, find it in their private interest to work to provide collective benefits to relevant groups. ${ }^{46}$

Hardin utiliza-se de uma analogia com um empreendedor do mundo corporativo para explicar os principais comportamentos dos empreendedores políticos, quais sejam, fundar e expandir organizações, procurar benefícios coletivos para outros membros. ${ }^{47}$ Em suma, sua principal função resume-se a arcar desproporcionalmente com os custos da ação coletiva, em troca de projeção e liderança. Uma hipótese de empreendedorismo político, que será vista mais à frente, é a relação entre a criação do G20 e da projeção internacional (liderança) que o Brasil buscou, durante a última década, no âmbito das negociações agrícolas da Rodada Doha da OMC. O Brasil, em busca dessa projeção e de um objetivo concreto, passaria a coordenar a ação do grupo em conjunto com outros PEDs e PMDRs (Países de Menor Desenvolvimento Relativo) que faziam parte da coalizão, mas arcavam desproporcionalmente com os custos de ação coletiva.

De maneira geral, em que pese às diferenças e similaridades de conceitos e processos metodológicos, tanto a análise de Olson quanto a de Hardin atuaram como propulsoras de diversos estudos relacionados à ação coletiva e aos interesses dos membros do grupo. Olson pautou-se pelo estudo do tamanho da coalizão como fator restritivo à coordenação da ação grupal, enquanto que Hardin, em geral, apresentou a possibilidade de o dilema da ação coletiva ser superado em grupos latentes por meio dos side-payments e da presença de um empreendedor político.

O fato de os dois receberem atenção especial nesse estudo remete à necessidade de destacar conceitos, expostos por ambos os autores, que serão fundamentais para o estudo posterior do G-20.

No que se refere à análise de Olson, procurar-se-á saber com qual categoria de agrupamento destacado pelo autor o bloco negociador pode ser relacionado. Além disso, será necessário identificar qual a influência dos side payments no âmbito intracoalizão. Em relação a Hardin, por conta de o conceito de empreendedorismo político remeter ao conceito de liderança política (que será explorado no próximo tópico), analisar-se-á se o Brasil efetivamente exerceu liderança na formação da coalizão, assumindo desproporcionalmente os custos de ação coletiva em busca de projeção no Sistema Multilateral de Comércio.

\footnotetext{
${ }^{46}$ HARDIN, Russel. Collective Action. Baltimore, 1982, The John Hopkins University Press, p.35

${ }^{47}$ Idem, p.36
} 


\subsection{O Liderança Política nas Relações Internacionais}

Conforme exposto previamente, o foco do presente trabalho é o estudo da liderança intracoalizacional, mais especificamente a que diz respeito ao papel do Brasil, no âmbito do G20 agrícola da OMC, durante a Rodada Doha de negociações comerciais. Dessa forma, no intuito de complementar a análise inicialmente realizada, que diz respeito ao processo de formação e atuação das coalizões, lança-se mão, neste momento, de importantes reflexões acerca do fenômeno da liderança, expostas ao longo da segunda metade século XX.

Apesar da necessidade de realização de um recorte teórico específico para este estudo, deve-se ter presente que a discussão sobre diversos aspectos que se relacionam, direta ou indiretamente, com o fenômeno da liderança política conta com eminentes autores caros em termos conceituais e analíticos, como Nichollo Maquiavelli, durante o século XVI, e Max Weber, durante o século XIX e início do século $\mathrm{XX}^{48}$.

Por ser um dentre os vários níveis de análise do fenômeno da ação coletiva ${ }^{49}$, o papel da liderança está diretamente relacionado aos outros níveis existentes, como: motivação dos atores, estabilidade do grupo, durabilidade, contexto geral, estratégias, entre outros. Pode-se afirmar que, de maneira geral, diversos fatores relacionados a tais níveis de análise interferem de maneira distinta no processo de formação e atuação das coalizões nos variados fóruns de negociação internacional.

Especificamente no que diz respeito aos fatores relacionados à liderança em um grupo, tais como, (a) os interesses individuais, (b) a dinâmica de tomada de decisão, (c) o número de stakeholders do bloco, entre outros, pode-se afirmar que há uma influência direta dessas variáveis no estudo do tema, esteja ele inserido em um contexto político mais amplo ou associado a uma negociação específica. Dessa forma, algumas características intrínsecas à liderança, que derivam dessa influência, merecem destaque pelos autores ora explorados, principalmente no que se refere à complexidade em mensurar ou quantificar o fenômeno, aos

\footnotetext{
${ }^{48}$ Em sua clássica obra "O Príncipe", Machiavelli discorre acerca de diversas maneiras de gerenciamento do governo e centralização do poder por parte do governante. Já Max Weber, em sua obra "Economia e Sociedade", apresenta os três tipos puros de dominação legítima (legal, tradicional e carismática), as quais se tornaram fonte de um extenso debate promovido por diversos autores posteriores a ele.

49 OLIVEIRA, Amâncio J., ONUKI, Janina e OLIVEIRA, Emmanuel. Coalizões Sul-Sul e multilateralismo: Índia, Brasil e África do Sul. In: OLIVEIRA; Amâncio J., ONUKI, Janina, Coalizões Sul-Sul e as negociações multilaterais: os países intermediários e a coalizão IBSA. São Paulo: Mídia Alternativa Comunicação e Editora, 2007, p. 23.
} 
mecanismos de controle existentes no ambiente coletivo, aos diferentes perfis de liderança existentes, à relação entre líder e liderado, entre outras.

O cientista político canadense Léon Dion, em seu artigo "The concept of Political Leadership", de 1968, alertava sobre a necessidade de as teorias científicas estabelecerem, à época, um conceito menos precário e mais robusto de liderança política. Segundo ele, a maioria das análises ainda refletia, aperfeiçoava ou retificava as visões expressas por Max Weber. Além disso, segundo o autor, a despeito dos esforços de algumas técnicas sociométricas terem tentado mostrar novas dimensões de liderança, a crescente complexidade na relação entre traços pessoais e ambiente passava, gradualmente, a demandar que critérios mais claros fossem utilizados para a mensuração e determinação precisa desse fenômeno.

Haveria, todavia, segundo Dión, um consenso geral entre os especialistas acerca de dois aspectos centrais do tema: (a) a liderança é uma relação entre uma ou mais pessoas que exercem influência e uma ou mais pessoas que se submetem a esse tipo de influência; (b) a liderança política é uma relação melhor estudada quando inserida em contexto de "group process", ou seja, quando analisada como resultado de diversas interações entre os membros do grupo, as quais tomam a forma de um padrão estruturado de autoridade e subordinação 50 .

Ao analisar o fenômeno da liderança política essencialmente sob dois primas (natureza e exercício), o autor expõe a existência de diversos modelos de interação entre o(s) líder(es) e seus subordinados, bem como os diversos mecanismos de controle da liderança tanto por parte de quem a exerce quanto por parte de outros membros do grupo.

No que se refere à natureza da liderança política, o autor dá relevância à necessidade de se analisar o fenômeno como um padrão que tem como base três componentes essenciais, quais sejam: o líder, os seguidores e a relação funcional existente entre eles (esta última fundamental para propósitos analíticos). Segundo Dión:

Most studies on leadership are deficient precisely because they do not even recognize the existence of this third element. When this happens, debates over the relative importance in leadership of personal traits on the one hand and the situation on the other become sterile since the two sets of factors are seen as mutually exclusive. When leadership is defined as a pattern,

\footnotetext{
${ }^{50}$ DION, Léon. The Concept of Political Leadership: An Analysis. Canadian Journal of Political Science, Vol.1, nº1, Mar. 1968, p. 2-4.
} 
however, it becomes apparent that is both a function of the social situation and a function of personality, as well as a function of these two interaction ${ }^{51}$.

Nesse contexto de interação, uma das principais características do líder, segundo o autor, é sua habilidade de refletir as normas e as aspirações do grupo, porém com a sensibilidade necessária para aperfeiçoar os padrões e fomentar o desempenho da coletividade. Essa dupla função do líder, de agente conservador e, ao mesmo tempo, inovador, no âmbito da ação coletiva, é um exemplo do que Dión chama de modelo circular de interação.

Além disso, o autor destaca outras características fundamentais do fenômeno, como: o fato de esse abarcar uma ampla variedade de interações diferentes e simultâneas entre os mais variados atores; a existência de uma complexa rede de centros de poder interligados e que por vezes competem entre si; a complementaridade necessária entre qualidades pessoais e o contexto geral como fator causal do fenômeno. ${ }^{52}$ Especificamente a essa última, tal complementaridade, segundo o autor, faz com que outra relação cíclica, com dois aspectos centrais seja vista na dinâmica da liderança política dentro de um grupo: primeiramente, a definição de um objetivo e as circunstâncias para alcançá-lo criam uma demanda coletiva por liderança; em seguida, o líder passaria gradualmente a influenciar as normas e a estrutura do grupo $^{53}$. Em um primeiro momento, como se pode perceber, haveria uma clara influência do contexto (ambiente) na emergência de um líder, com características (traços pessoais) que atendam às demandas e às expectativas dos outros membros do grupo. No exercício de sua função, o líder tenderia a influenciar diretamente a estrutura coletiva, modificando-a para também atender, mesmo que parcialmente, aos seus interesses.

O autor, no entanto, apesar de não discorrer extensamente acerca desses interesses (ou idiossincracias, como ele mesmo propugna), lança a ideia de uma interessante dinâmica intragrupo, marcada pela constante interação entre interesses coletivos e individuais, a qual se reflete na estrutura, nas normas e nos objetivos do agrupamento. Essa ideia retoma, em certa medida, a análise exposta previamente por Mancur Olson, sobretudo no que tange aos diferentes perfis existentes no âmbito da ação coletiva e as disparidades de interesses entre os atores que a consubstanciam.

\footnotetext{
${ }^{51}$ DION, Léon. The Concept of Political Leadership: An Analysis. Canadian Journal of Political Science, Vol.1, nº1, Mar. 1968, p. 4.

${ }^{52}$ Idem, p.6

${ }^{53}$ Idem, p.6.
} 
No que tange ao outro polo de análise do autor - o exercício da liderança - Dión infere que este deve ser visto à luz de três diferentes prismas, quais sejam: (a) a seleção de líderes, (b) os mecanismos de controle e, por fim, (c) os diferentes estilos de liderança.

No que se refere à seleção dos líderes, ou seja, ao processo de qualificação de um membro como liderança do grupo, o autor se defronta com a questão do fundamento moral da liderança (a qual pode emergir ou ser imposta aos demais) e do acesso à posição de líder (que pode ser dinâmica aberta ou fechada). Apesar das diversas propostas de adequação de um determinado caso a essas categorias de análise, o autor adverte que essas devem ser vistas mais propriamente como tipos ideais de categorização do que opções mutuamente excludentes de caracterização, já que, segundo ele:

In actual political systems consent and force are present in varying proportions, while access to leadership positions is never perfectly open to all and rarely absolutely restricted to a few ${ }^{54}$.

Em relação aos mecanismos de controle, o autor atesta preocupação em explorar como os membros do grupo condescendem com a liderança e como os membros também controlam seus líderes. Por conta da diversidade de mecanismos utilizados em diferentes esferas de poder, o autor se foca mais na natureza desses mecanismos do que em seus aspectos operacionais. Segundo ele, um importante aspecto de controle (seja do líder para com seus subordinados, ou vice-versa) são, em sentido amplo, as normas intragrupo. Segundo Dión, as normas legitimam e limitam o funcionamento da liderança e estabelecem os padrões de autoridade, decidindo como ela será exercida.

A relação complementar entre a emergência do líder e a influência (explorada previamente) ganha força quando o tema são as normas do grupo. Isso porque, após ter seu papel legitimado, o líder, por possuir uma a visão estratégica do processo de tomada de decisão intragrupo, tem uma grande vantagem sobre os demais membros, podendo exercer influência direta na manutenção ou alteração das normas, de acordo com seus interesses.

Dessa forma, a ingerência sobre as normas, bem como sobre os valores operacionais do grupo, configuram uma importante fonte de poder do líder. Na mão contrária, todavia, o agrupamento (em sentido amplo) também exerce influência sobre seus líderes por meio das normas, da burocracia e das regras do jogo, o que faz o autor lembrar que, apesar do aparente

\footnotetext{
${ }^{54}$ DION, Léon. The Concept of Political Leadership: An Analysis. Canadian Journal of Political Science, Vol.1, nº1, Mar. 1968, p.11.
} 
domínio do líder sobre o grupo, após a legitimação do seu papel, esse, por muitas vezes, ainda é menor do que a organização 55 .

Em relação aos estilos de liderança, conceito que deve obrigatoriamente abarcar tanto o estilo de comando (comportamento) do líder quanto os padrões de autoridade (contexto, normas), Dión identifica quatro tipos diferentes de liderança: (a) a laissez-faire; (b) a democrática; (c) a autoritária e (d) a autocrática. Enquanto as duas primeiras são de cunho democrático e apresentam características como deliberação e definição coletiva da estratégia, as duas últimas têm uma raiz autoritária, em que o papel do líder é o de coagir e controlar as atitudes dos membros para que o objetivo seja atingido. Em suma, o autor não opta em prol de um tipo de liderança em detrimento de outro, porém indica brevemente quais são os objetivos de cada estilo: enquanto as lideranças de cunho democrático visam à realização ótima dos objetivos do grupo por meio de um controle mínimo dos seus membros; nas de raiz autoritária prevalece a determinação unilateral, por parte dos líderes, da política geral e dos meios para alcançar os objetivos, sem a formalização da participação direta de outros membros nesses $\operatorname{processos}^{56}$.

Referência no assunto, o estudo "The Comparative Analysis of Political Leadership", de Lewis J. Edinger ${ }^{57}$, expõe os principais fatores que caracterizam um líder, diferenciando dois tipos distintos de liderança e indicando as fontes e a magnitude desse processo.

Para o autor, apesar de a maior parte das análises relacionar liderança a diversos fatores como poder, influência, comando, autoridade ou controle; o exercício de análise desse fenômeno, ao longo do tempo, fez com que a formação de um conceito em torno do tema se tornasse cada vez mais complexo. Em suma, no entanto, há duas grandes definições: (a) liderança posicional e (b) liderança comportamental ${ }^{58}$.

A primeira está associada com os direitos e deveres de um cargo ou status em uma determinada estrutura hierárquica, seja em uma organização formal ou coletividade informal. A interrelação ocorre em termos de posições. O líder, em um contexto posicional, é um título, ou seja, é algo definido objetivamente. A liderança comportamental, por sua vez, relaciona-se

\footnotetext{
${ }^{55}$ DION, Léon. The Concept of Political Leadership: An Analysis. Canadian Journal of Political Science, Vol.1, nº 1 Mar. 1968, p. 13.

${ }^{56}$ Idem, p. 15.

${ }^{57}$ EDINGER, Lewis J., The Comparative Analysis of Political Leadership. Comparative Politics, Vol. 7, $\mathrm{N}^{\circ} 2$, 1975, p.253-269.

${ }^{58}$ Idem, p. 255-256.
} 
a pessoas que moldam as ações de outras pessoas, sendo que a foco da interrelação é pessoal. A identificação de um líder nesse caso ocorre por meio de uma associação de causa-efeito.

Interessante notar que, para o autor, o ponto em comum dessas definições é, justamente, o fato de ambas conceberem liderança política em termos de controle formal sobre os benefícios e obrigações de um determinado grupo. No entanto, quando se analisa a liderança comportamental, é importante destacar que, segundo Edinger:

Individuals are said to be leaders in an interpersonal relationship when it can be shown that the behavior of the other participants is a response to their stimuli, and not random, routine, accidental, or attributable to other factors ${ }^{59}$.

Dessa forma, em relação a este tipo de liderança, a simples imposição de uma obrigação ou ordem não caracterizaria um líder, mas sim a argumentação de que o benefício do comprometimento em torno de um tema traria mais benefícios do que custos. Dessa forma, há a intenção de um líder de um lado e a oportunidade de escolha do seguidor de outro. Esse approach causal de identificação de um líder político relaciona-se diretamente a três suposições analíticas: (a) o líder é tido como um agente independente; (b) ele busca o controle sobre o comportamento dos outros atores e (c) os seus seguidores teriam, supostamente, uma escolha em segui-lo. Essas suposições, segundo o autor, auxiliariam na análise empírica da liderança, tanto no que se refere ao foco da pesquisa quanto no isolamento de variáveis-chave, uma vez que, o estabelecimento de determinados critérios, como a vontade do líder e a capacidade de escolha dos potenciais seguidores, podem esclarecer se determinada ação tomada pelos membros do grupo vai ao encontro do interesse da liderança.

No que se refere às fontes da liderança, Edinger diferencia quatro vieses analíticos existentes nas pesquisas sobre o tema, os quais indicam que a liderança seria uma função: do contexto de escolha dos atores envolvidos (regras e normas organizacionais, exigências das situações); do desequilíbrio no acesso e distribuição de recursos (status, votos, bem estar, armas); das disposições atitudinais dos seguidores (preferências, expectativas cognitivas, senso de solidariedade) e, por fim, da motivação, orientação e do estilo do comportamento do agente controlador (ambição, dedicação, habilidades) ${ }^{60}$.

Apesar de o foco das pesquisas em relação à magnitude da liderança ser a mensuração comparativa entre a intenção do líder e a mudança de comportamento do liderado, o autor

\footnotetext{
${ }^{59}$ EDINGER, Lewis J., The Comparative Analysis of Political Leadership. Comparative Politics, Vol. 7, №2, $1975, \mathrm{p} 258$.

${ }^{60}$ Idem, p. 261
} 
destaca problemas quanto a esse tipo de mensuração, advindos, sobretudo, dos níveis de mudança comportamental e dos critérios escolhidos para medir essa mudança. Ainda no que se relaciona ao escopo das análises, Edinger indica que os estudos comparativos sobre o tema analisam três aspectos distintos, porém interrelacionados da liderança política: (a) variância nos esforços para obter controle (aquisição da liderança); (b) variância no exercício do controle (desempenho da liderança) e (c) variância no impacto desse controle (consequências da liderança) ${ }^{61}$. Tais indicadores geram também diferentes tipos de afirmações em relação à análise. São elas: as descritivas, designando diferenças e similaridades; as explicativas, deduzidas de um modelo teórico ou induzidas por evidências e, por fim, as prescritivas, advindas de associações causais que expõem o que os líderes ou seguidores devem fazer para atingir determinados objetivos ${ }^{62}$.

Por fim, sempre atento ao incremento do rigor metodológico e operacionalização da pesquisa na área, o autor destaca alguns fatores-chave para que se alcance um bom resultado. A escolha de critérios relevantes para a pesquisa deve realizada para que o isolamento dessas variáveis gere um bom resultado na relação causal que será utilizada para a mensuração da liderança. Além disso, a obtenção de informações com qualidade, que realmente retratem uma determinada realidade a ser observada, bem como uma mensuração refinada das variáveis independentes, que retrate com o máximo de segurança a relação causal e o impacto final na variável dependente, são fatores essenciais para a qualidade do trabalho empírico. Por fim, o refino na interpretação dos dados obtidos é fundamental para que essa qualidade se consolide independentemente do uso de métodos matemáticos, conforme indica o próprio autor ${ }^{63}$.

Em "Political leadership and regime formation: on the development of institutions in international society", o cientista político Oran R. Young contribui sobremaneira para o debate relacionado aos tipos de liderança no sistema internacional. Lançando mão de exemplos ora referentes à ação de países em importantes momentos históricos, ora relacionados à atuação de negociadores em arenas multilaterais, o autor analisa a natureza do fenômeno da liderança política no contexto da barganha institucional e da consequente formação de regimes internacionais. Para o autor:

Leadership is a critical determinant of success or failure in the processes of institutional bargaining that dominate efforts to form

\footnotetext{
${ }^{61}$ EDINGER, Lewis J., The Comparative Analysis of Political Leadership. Comparative Politics, Vol. 7, №2, 1975, p.267.

${ }^{62}$ Idem, p.268.

${ }^{63}$ Idem, p.269.
} 
international regimes or, more generally, institutional arrangements in international society ${ }^{64}$.

Com o intuito de aprofundar o estudo sobre a política da formação de regimes internacionais, o autor se propõe a fazer três importantes análises. Primeiramente, discorre acerca da natureza da barganha institucional para, em seguida, explorar os principais aspectos do papel da liderança. Por fim, identifica três tipos de liderança que operam (por vezes simultaneamente) no âmbito da barganha institucional: (i) a estrutural, (ii) a empresarial e, por fim, (iii) a intelectual.

No que se refere à barganha institucional, o autor a define em termos de um conjunto de esforços da parte de atores que buscam acordar regras entre si, para que, posteriormente, o parte do seu relacionamento seja norteado por elas ${ }^{65}$. A busca pelo consenso e pela elaboração de um corpo de normas, todavia, é uma dinâmica que se depara recorrentemente com problemas de ação coletiva (assimetrias de poder, diversidade de interesses, problemas relacionados à dinâmica dos jogos de níveis ${ }^{66}$, etc.), que dificultam e até mesmo podem paralisar uma negociação. Esse ambiente complexo, todavia, formaria, de acordo com o autor, as bases para que uma liderança política emerja no processo negociador, a qual carregaria consigo a responsabilidade de mitigar os efeitos dos problemas de ação coletiva inerentes à negociação.

Leadership [...] refers to the actions of individuals who endeavor to solve or circumvent the collective action problems that plague the efforts of parties seeking to reap joint gains in processes of institutional bargaining ${ }^{67}$.

Ao abordar a natureza da liderança política, Young deixa evidente a dificuldade intrínseca ao tema no que se refere à clarificação do papel da liderança. Para ele, um equívoco recorrente na pesquisa diz respeito à concentração de análises referentes à associação existente entre uma barganha institucional que obteve sucesso e as ações de determinados atores que, aparentemente, contribuíram para isso. Segundo Young, obter-se-ia resultados mais robustos, se a análise do papel da liderança fosse feita com base nas ações específica dos atores sem que houvesse referência ao sucesso ou falha do regime.

\footnotetext{
${ }^{64}$ YOUNG, Oran R. Political Leadership and Regime Formation: On the development of Institutions in International Society. International Organization, Vol.45, n³, 1991, p.281

${ }^{65}$ Idem, p. 282

${ }^{66}$ PUTNAM, Robert D. Diplomacy and Domestic Politics: The Logic of Two-Level Games. International Organization, Vol. 42, No. 3, 1988, p. 427-460.

${ }^{67}$ YOUNG, Oran R. 1991, op cit., p. 285
} 
Outro problema destacado pelo autor diz respeito ao fato de pesquisadores associarem a formação bem sucedida de regimes à existência de uma hegemonia no processo negociador. Segundo Young, essa abordagem ofuscaria o papel que diversos players têm em uma determinada negociação. Segundo ele, para que sejam evitados transtornos quanto às contribuições dos atores e, principalmente, dos líderes no processo negociador, a análise do fenômeno da liderança deve ser pautada na ação dos principais atores, porém diferenciando seu comportamento quanto ao tipo de liderança colocada em prática e analisando a interação existente entre eles:

To overcome the resultant confusion concerning the contributions leaders make to regime formation, I argue, we must approach leadership in behavioral terms, focusing on the actions of individuals, differentiating analytically among several forms of leadership, and then analyzing the interactions among them. I call these forms of leadership structural leadership, entrepreneurial leadership, and intellectual leadership ${ }^{68}$.

O primeiro tipo de liderança explicitado acima pelo autor encontra referência na relação direta entre o poder estrutural e o poder de barganha decorrente das assimetrias entre os membros no processo de barganha institucional. Em face dos diversos problemas de ação coletiva presentes na negociação, a principal habilidade do líder estrutural é, segundo Young, traduzir poder estrutural em poder de barganha, como a principal forma de alcançar um acordo:

Structural leaders are experts in translating the possession of material resources into bargaining leverage cast in terms appropriate to the issues at stake in specific instances of institutional bargaining ${ }^{69}$.

Segundo Young, a liderança estrutural pode ser hegemônica (um ator estaria encarregado de prover bens coletivos ao grupo), ou coletiva (modelo go-it-alone-power ${ }^{70}$ ), na qual um grupo de atores poderiam funcionar como líderes estruturais e dispender esforços conjuntos para alcançarem um resultado de comum interesse entre eles em uma determinada negociação ${ }^{71}$.

Geralmente, os líderes estruturais podem ter um Best Alternative for a Negotiated Agreement (BATNA) maior do que as diversas contrapartes que estão negociando, o que faz

\footnotetext{
${ }^{68}$ YOUNG, Oran R. Political Leadership and Regime Formation: On the development of Institutions in International Society. International Organization, Vol.45, n³, 1991, p.287

${ }^{69}$ Idem, p. 288-289.

${ }^{70}$ GRUBER, Lloyd. Ruling the World: Power Politics and the Rise of Supranational Institutions. Princeton, Princeton University Press, 2000.

${ }^{71}$ YOUNG, Oran R. 1991, op. cit., p. 290.
} 
com que um possível não-acordo não lhes cause tanto prejuízo comparado aos outros players, que podem ter mais interesse no fechamento do acordo. Dessa forma, dependendo dos interesses do líder estrutural durante a negociação, ele pode efetivamente lançar mão, em face dos demais atores presentes no processo negociador, de táticas de pressão (side payments), visando a acelerar o fechamento do acordo, ou de ameaça (interrupção da negociação, por ex.) visando à implementação de suas preferências ${ }^{72}$.

Em suma, esses líderes têm, como característica central durante uma negociação, a busca pela realização dos self interests, os quais estariam, segundo Young, relacionados muito mais diretamente a aspectos intangíveis (glória, respeito, manutenção do status quo) do que a recompensas materiais propriamente $\operatorname{ditas}^{73}$.

A liderança empresarial, por sua vez, relaciona-se com a habilidade do negociador individual ou coletivo representar seus interesses durante o processo de negociação ${ }^{74}$. A sua competência em elencar questões relativas à negociação de maneira a promover avanço na barganha integrativa é, certamente, o ponto mais ressaltado pelo autor quando descreve esse tipo de liderança ${ }^{75}$. A sua origem está associada a dois fatores: a existência de problemas de ação coletiva e de excedentes de barganha (bargainer's surplus ${ }^{76}$ ). Segundo o autor, a ocorrência de diversos problemas de ação coletiva pode reduzir a viabilidade de que os atores congreguem esforços para capturar o excedente de barganha e, assim, chegarem a um acordo. Essa situação mista de impasse na negociação e viabilidade de consenso, segundo Young:

[...] provides an opening for entrepreneurial leaders to assume various roles, in helping those engaged in institutional bargaining to reap the bargainer's surplus ${ }^{77}$.

Outras formas de atuação do líder empresarial diz respeito à possibilidade de pautar a agenda negociadora (agenda setter), fomentar o debate acerca de temas específicos, apresentar soluções para áreas-chave da negociação e intermediar possíveis soluções entre os negociadores ${ }^{78}$. O autor destaca, contudo, que, para que a atuação do líder empresarial tenha mais eficácia, a negociação deve ter um senso de urgência. Além disso, é importante destacar

\footnotetext{
72 YOUNG, Oran R. Political Leadership and Regime Formation: On the development of Institutions in International Society. International Organization, Vol.45, nº3, 1991, p.288.

${ }^{73}$ Idem, p. 293.

${ }^{74}$ Idem, p. 296.

${ }^{75}$ Idem, p. 293.

76 “A bargainer's surplus exists whenever an identifiable set of parties can reap joint gains by coordinating their behavior in a mutually agreeable fashion”. Em: YOUNG, Oran R. 1991, op. cit., p. 293.

${ }^{77}$ Idem, p. 294

${ }^{78}$ Idem.
} 
que esse tipo de liderança não está associado somente à atuação de um player, podendo ser exercido por diversos atores e das diversas maneiras expostas acima:

When we turn to entrepreneurial activities [...] there is no barrier to the emergence of multiple leaders; simultaneous efforts on the part of a number of individuals endeavoring to frame the issues, invent opinions, or broker interests of the principals constitute a common occurrence in international negotiations ${ }^{79}$.

O líder intelectual difere-se sobremaneira dos dois tipos de liderança já citados. Ao ser responsável por gerar capital intelectual e sistemas de pensamento que moldam as perspectivas dos participantes da barganha institucional, esse tipo de liderança caracteriza-se, sobretudo pela dinâmica da construção e difusão de ideias em que está inserido. Geralmente, está associado ao início do processo negociador, aos pilares e princípios que permearão toda a discussão.

While the structural leader seeks to translate power resources into bargaining leverage, the intellectual leader relies on the power of ideas to shape intellectual capital available to those engaged in institutional bargaining. [...] Whereas the entrepreneurial leader is an agenda setter and popularizer who uses negotiating skill to devise attractive formulas and to broker interests, $[\ldots]$ the intellectual leader is a thinker who seeks to articulate the systems of thought that provide the substratum underlying the proximate activities involved in institutional bargaining ${ }^{80}$.

Com o sentido de ilustrar, Young cita, como exemplo de um líder intelectual, o economista inglês John Maynard Keynes e a sua atuação durante o contexto econômico e político durante a década de 1930, em que Keynes teria articulado as bases intelectuais para um tipo de pensamento econômico que ficou conhecido posteriormente como "embebed liberalism", e que iria pautar os sistemas financeiro e comercial internacionais até durante as década posteriores. Outros temas contemporâneos também ganharam notoriedade por meio da atuação de lideranças intelectuais, sejam elas individuais ou coletivas, como, por exemplo , nos debates sobre desenvolvimento sustentável e segurança ambiental ${ }^{81}$.

Segundo Young, o estabelecimento de instituições internacionais efetivas requer a interação de, no mínimo, duas formas de liderança por ele exemplificadas. $\mathrm{O}$ autor, por fim, explica que, no contexto da relação entre o fenômeno da liderança e o estabelecimento de

\footnotetext{
${ }^{79}$ YOUNG, Oran R. Political Leadership and Regime Formation: On the development of Institutions in International Society. International Organization, Vol.45, n³, 1991, p.297.

${ }^{80}$ Idem, p. 300.

${ }^{81}$ idem, p. 299-300.
} 
regimes internacionais, não se deve excluir a possibilidade as três formas de liderança aqui explicitadas poderem vir atuar concomitantemente em processos específicos de negociação ${ }^{82}$.

Com uma literatura voltada especificamente ao contexto das negociações multilaterais, o cientista político Arild Underdal dá uma importante contribuição analítica em torno das especificidades relacionadas ao papel do líder. O professor, que define liderança como "an asymmetrical relationship of influence in wich one actor guides or directs the behavior of other toward a certain goal over a certain period of time ${ }^{, 83}$ explica que a essa não pode ser baseada somente em coerção, mas deve ter como pano de fundo uma plataforma de valores compartilhados, interesses e crença que tende a ser expandida e consolidada na medida em que a liderança se firmar entre os membros. ${ }^{84}$

Quando transposta às negociações multilaterais, a lógica da liderança deve, contudo, ser compreendida por meio da relação entre as capacidades dos estados e comportamento individual dos mesmos.

For all practical purposes, certain capabilities and a certain minimum of effort and (tactical) behavior may be considered necessary conditions for being able to provide leadership in a negotiation process. ${ }^{85}$

Para o autor, "a leader provides a particular product (a particular set of services designed to achieve some particular purpose)", e uma vez que esse "produto" oferecido pelo líder for ao encontro das demandas de possíveis seguidores, estabelece-se uma relação denominada "líder-seguidor", e enquanto a oferta for ao encontro da demanda, esta reação perdurará. Underdal ainda identifica três tipos de liderança:

a) Liderança por meio da ação unilateral: ocorre geralmente no relacionamento intracoalizão, no memento de definição de agenda e estratégia negociadora e não na neociação intercoalizoes. É exercida quando "um ator ou um pequeno grupo de atores tomam medidas para resolver um problema coletivo por meio de seus próprios esforços, direcionando

\footnotetext{
${ }^{82}$ YOUNG, Oran R. Political Leadership and Regime Formation: On the development of Institutions in International Society. International Organization, Vol.45, n³, 1991, p. 302.

${ }^{83}$ UNDERDAL, Arild. "Leadership Theory: Rediscovering the arts of management", in WILLIAN ZARTMAN (org.): International Multilateral Negotiation, cap. 8, 1994, p. 178.

${ }^{84}$ Idem, p. 179.

${ }^{85}$ Idem, p. 182
} 
o ritmo para que os outros os sigam" ${ }^{, 86}$. Pode ocorrer tanto pelo elevado impacto que as decisões do líder têm no grupo, quanto pelo mecanismo de persuasão social. ${ }^{87}$

b) Liderança coercitiva: é baseada em um mecanismo de diplomacia tácita, que envolve promessas e ameaças, sendo basicamente um relacionamento de barganha distributiva $^{88}$, no qual o líder sempre tem que provar sua força reativa perante os outros membros do grupo ou do regime. Essa dinâmica pode ser associada, segundo o autor, com a Teoria da Estabilidade Hegemônica. ${ }^{89}$

c) Liderança instrumental ("Find de Way”): ocorre quanto há uma deliberação do grupo para que um determinado ator lidere a coalizão. Tal liderança foi "conquistada" pelo ator, baseada, principalmente na sua habilidade em liderar, no esforço que esse ator apresenta na análise das questões e, por fim, no status que ele ocupa dentro do grupo ou da organização. $^{90}$

No intuito de se diferenciar de análises que destacam os interesses dos atores como elementos fundamentais para a formação e manutenção da liderança intragrupo, o cientista político Jonas Talberg propôs uma abordagem diferente de análise do tema, ao salientar a importância de se estudar os efeitos da liderança relacionada ao processo de tomada de decisão no âmbito institucional ${ }^{91}$.

Para ele, o contexto das negociações no plano multilateral gera, por conta da ampla complexidade e multidimensionalidade temática, demanda por delegar poder (liderança) a

\footnotetext{
${ }^{86}$ UNDERDAL, Arild. "Leadership Theory: Rediscovering the arts of management", in WILLIAN ZARTMAN (org.): International Multilateral Negotiation, cap. 8, 1994, p. 183.

${ }^{87}$ Idem, p. 185.

${ }^{88}$ Em uma negociação, a barganha distributiva estaria em uma face oposta à integrativa. Segundo Narlikar e Hurrel: [...] the strict distributive strategy, also known as the value-claiming strategy [...] comprises a set of tactics that are functional only for claiming value from others and defending against such claiming, when one party's goals are partly in conflict with those of others. Examples of strict distributive strategies include: high opening demands, refusing all concessions, exaggerating one's minimum needs and priorities, manipulating information to others' disadvantage, taking others' issues hostage, worsening their BATNA (Best Alternative to a Negotiated Agreement), filing a legal complaint, issuing threats, imposing penalties. [...] The integrative or value-creating strategy, $[. .$.$] comprises a set of tactics that are instrumental to the attainment of goals that are not$ in fundamental conflict, and hence can be integrated for mutual gain to some degree. Examples include sharing information relatively openly to explore common problems or common threats; proposing an exchange of concessions that might benefit more than one party; reframing the issue space itself to ease an impasse. Em NARLIKAR, Amrita; HURRELL, Andrew; A New politics of confrontation? Developing countries at Cancun and beyond. Global Society, v. 20, n ${ }^{\circ}$ 4, 2006, p.10.

${ }^{89}$ UNDERDAL, Arild. 1994, op. cit., p. 187.

${ }^{90}$ Idem, p. 190.

91 TALBERG, Jonas. Formal Leadership in Multilateral Negotiations: A Rational Institutionalist Theory. The Hague Journal of Diplomacy. Estocolmo, 2006.
} 
alguém no âmbito institucional para que haja coordenação do processo, definição de prioridades e apresentação de resultados.

O autor, para embasar sua tese de necessidade de controle do processo negociador por um líder, criou a Teoria Institucionalista Racional da Liderança Formal, que tem como base elementos provenientes do/a:

(i) Institucionalismo da escolha racional: concepção de que Estados são agentes racionais que se comportam instrumentalmente na busca de suas preferências. Dessa forma, há uma visão de que a política é uma série de dilemas contratuais que podem impedir ou inibir trocas mutuamente vantajosas, e uma a perspectiva de que as regras formais são fatores que impulsionam e também restringem a ação.

(ii) Teoria da barganha racionalista: reconhecimento de problemas de ação coletiva nas negociações multilaterais e ênfase na tensão entre os movimentos cooperativos e competitivos da negociação. Com isso, a informação deve ser vista como um elemento de barganha, havendo uma perspectiva de líderes e empreendedores como atores estratégicos. Por fim, a análise ocorre em termos de eficiência e distribuição dos resultados negociados.

Para o autor, a dinâmica da negociação envolve dois campos distintos que se complementam em torno do resultado final: a demanda e a oferta pela liderança formal. Devido a problemas de ação coletiva (falhas na agenda, no processo negociador e na representação das partes) a barganha descentralizada no ambiente multilateral é inviabilizada. Com isso, os estados delegam à presidência (chairmanship) a necessidade de assumir determinadas funções processuais ${ }^{92}$, como (a) gerenciamento da agenda (tomar decisões relacionadas à sequência, frequência e método das negociações, bem com decisões específicas acerca do formato das reuniões, direito de fala, procedimento de voto, sumário dos resultados, entre outros); (b) intermediação da agenda (obtenção e retenção de informações essenciais sobre a preferências dos atores por meio de consulta, realização de draft texts, entre outros) e (c) representação da organização (seja em outros fóruns de tomada de decisão ou perante terceiros que não fazem parte da organização. Esse tipo de demanda se faz necessário devido

\footnotetext{
92 TALBERG, Jonas. Formal Leadership in Multilateral Negotiations: A Rational Institutionalist Theory. The Hague Journal of Diplomacy. Estocolmo, 2006, p. 120-125.
} 
à natureza interdependente do processo de tomada de decisão em alguns temas e agendas, por ex.: clima e comércio, comércio e direitos humanos, entre outros).

Dessa forma, o lado da oferta ${ }^{93}$ por liderança, segundo a Teoria de Talberg, passa a coordenar o processo de tomada de decisão entre as partes. Utilizando-se de informação privilegiada e controles procedimentais, a estrutura da presidência (por meio de um representante ou secretariado) coordena os grupos de negociação, no sentido de colher informações importantes para a criação de um texto final que apresente, sobretudo, eficiência e efeitos distributivos sobre os membros.

Talberg alerta, no entanto, para a necessidade de procedimentos operacionais, regras formais e desenhos institucionais que restrinjam o excesso de poder da estrutura da presidência no exercício do gerenciamento e intermediação da agenda, bem como na representação institucional. Segundo o autor, isso é necessário, pois apesar da necessidade de empowerment do chairman para o andamento das negociações, o excesso do poder, a concentração de informações relevantes e a possibilidade de interferência direta no processo podem fazer com que interesses individuais se sobreponham aos coletivos.

Por fim, cabe salientar a contribuição teórica de Janina Onuki e Amâncio Oliveira quanto à elaboração de uma tipologia exaustiva de liderança baseada em duas variáveis, quais sejam, a tangibilidade das fontes de poder e a coercitividade no uso de tais fontes ${ }^{94}$. Para ambos, a liderança faz parte de uma das distribuições funcionais dos negociadores em cada uma das equipes da negociação. O líder, afirmam, “detém o mais importante papel em uma equipe negociadora".

Liderar é, antes de tudo, conduzir. Por conduzir entende-se levar um grupo a uma determinada direção para atingir um objetivo utilizando um dado meio. A liderança requer, portanto, legitimidade, sentido de direção, meta e estratégia ${ }^{95}$.

Com o intuito de combinar parâmetros para demonstrarem a existência de tipos específicos de liderança, os autores lançam mão de um cruzamento das duas importantes

\footnotetext{
${ }^{93}$ TALBERG, Jonas. Formal Leadership in Multilateral Negotiations: A Rational Institutionalist Theory. The Hague Journal of Diplomacy. Estocolmo, 2006, p. 129-138.

${ }_{94}$ OLIVEIRA, Amâncio; Onuki Janina. Negociações Internacionais: Teoria e Técnicas. In: AYERBE, Luis Fernando; BOJIKIAN, Neusa (Orgs.), Negociações Econômicas Internacionais: Abordagens, atores e perspectivas desde o Brasil. São Paulo: Editora UNESP: Programa San Tiago Dantas de Pós Graduação, 2011, p.21.

${ }^{95}$ Idem, p. 20.
} 
dimensões já citadas, que tem como resultado quatro tipos de liderança, conforme observado no Quadro 2:

\section{Quadro 2 - Tipologia derivada do cruzamento tangibilidade versus coercitividade}

\begin{tabular}{|c|c|c|}
\hline Bens & Persuasão / Benefício & Coeração/Custo \\
\hline Intangíveis & I. Liderança Persuasiva & II. Liderança Coercitiva \\
(recursos não materiais) & Instrumental (Lipi) & Instrumental (Lici) \\
\hline Tangíveis & III. Liderança Persuasiva & IV. Liderança Coercitiva \\
(recursos materiais) & Estrutural (Lipe) & Estrutural (Lice) \\
\hline
\end{tabular}

Fonte: OLIVEIRA, Amâncio; Onuki Janina. Negociações Internacionais: Teoria e Técnicas. Em AYERBE, Luis Fernando; BOJIKIAN, Neusa (Orgs.), Negociações Econômicas Internacionais: Abordagens, atores e perspectivas desde o Brasil. São Paulo: Editora UNESP: Programa San Tiago Dantas de Pós Graduação, 2011, p.21.

Nessa tipologia, dependendo da fonte de poder utilizada (tangíveis ou intangíveis), os líderes podem prover benefícios ou custos aos liderados. Dessa dinâmica, depreende-se que o líder mais completo seria aquele que detém as duas fontes de poder (diversificação) e a habilidade necessária para lançar mão de estratégias de coerção ou persuasão, dependendo da ocasião (versatilidade) $)^{96}$. Os autores, todavia, chamam a atenção para a dificuldade da existência de atores que tenham tamanho grau de diversificação de fontes de poder e versatilidade em seu uso:

O mais comum é encontrar líderes que se restrinjam a uma fonte de poder e a utilizem recorrentemente. Em partes, isso ocorre por causa daquilo que podemos chamar de paradoxo do poder duro. Quem tem muito poder material tende a ficar arrogante e a perder a sensibilidade política, um prérequisito par ao bom exercício da liderança instrumental persuasiva ${ }^{97}$.

Como se pode perceber, a agenda de pesquisa em torno do fenômeno da liderança é ampla e está em processo de formação. Seja por vezes relacionada a aspectos específicos de um tipo de negociação ou a um contexto político mais amplo, uma característica fundamental do tema - e que por vezes foi enfatizada pelos autores ora citados - diz respeito à dificuldade de mensurar e tipificar padrões de liderança política. A necessidade de identificar critérios que retratem fidedignamente a realidade a ser estudada, fazendo com que os principais líderes dos mais variados processos negociadores sejam reconhecidos como tal, faz parte do processo de aperfeiçoamento teórico que vive o tema.

\footnotetext{
${ }^{96}$ OLIVEIRA, Amâncio; Onuki Janina. Negociações Internacionais: Teoria e Técnicas. Em AYERBE, Luis Fernando; BOJIKIAN, Neusa (Orgs.), Negociações Econômicas Internacionais: Abordagens, atores e perspectivas desde o Brasil. São Paulo: Editora UNESP: Programa San Tiago Dantas de Pós Graduação, 2011, p. 22.

${ }^{97}$ Idem, p.23.
} 
A agenda de negociações multilaterais (comercial, ambiental, entre outras), seja em âmbito multi ou bilateral e envolvendo blocos regionais ou países, tem contribuído de forma relevante para a expansão dessa área de pesquisa e para a clarificação de conceitos. É essencial que, por meio dessas negociações, pesquisadores identifiquem os principais elementos que corroborem a influência do líder no processo de obtenção, manutenção e gerenciamento das consequências do exercício dessa liderança.

É com esse propósito que os próximos capítulos serão embasados. Por meio da dinâmica de atuação do G20, no âmbito da Rodada Doha da OMC, com destaque para o papel do Brasil nos diversos momentos em que o grupo atuou como importante interlocutor no processo negociador, procurar-se-á expor os principais fatores que caracterizarão o país como o líder ou um dos líderes do agrupamento. 


\section{O G20 e Rodada Doha da OMC: Liderança brasileira nas negociações multilaterais sobre o comércio agrícola}

O presente capítulo expõe as principais determinantes da regulação do comércio agrícola em nível multilateral e, em seguida, analisa os dois elementos da agricultura nacional que justificam o engajamento do Brasil nessas negociações na OMC. Por fim, após a análise da atuação do G20 durante a Rodada Doha, expõe-se os resultados da análise empírica da liderança do Brasil no âmbito do G20 agrícola.

\subsection{A regulação do comércio agrícola no âmbito multilateral}

Desde o início da efetiva regulação do Sistema Multilateral de Comércio (SMC), com a assinatura do GATT em 1947, o processo de liberalização comercial priorizou, por mais de quarenta anos, os bens não-agrícolas em detrimento dos produtos agrícolas. ${ }^{98}$ Apesar do incremento de temas e de países durante as Rodadas de Negociação do GATT, o tema agrícola foi diretamente abordado somente na Rodada Uruguai (1986-1994), que culminou com a assinatura de uma gama de acordos, dentre eles um que constituía a OMC e outro que lançava bases para a regulação do comércio agrícola entre os 123 países signatários à época.

\footnotetext{
${ }^{98}$ A OMC divide os produtos comercializados entre os países em agrícolas e não agrícolas. Basicamente, os produtos agrícolas compreendem os capítulos 1 a 24 do Sistema Harmonizado 2007 (SH 2007), com exceção do capítulo 3 ("Peixes e Produtos da Pesca"). Os produtos não agrícolas estão presentes, em sua grande maioria, entre os capítulos 25 e 97. Para maiores informações, consultar: WTO, World Tariff Profile 2010, p. 24-25. Disponível em <http://www.wto.org/english/res_e/booksp_e/tariff_profiles10_e.pdf>. Acesso em 07/05/2012.
} 
Quadro 3 - Rodadas de Negociação na história do Sistema Multilateral de Comércio

\begin{tabular}{|c|c|c|c|}
\hline \multicolumn{4}{|c|}{ Rodadas de Negociação na história do sistema multilateral de comércio } \\
\hline Rodada & Período & Países Participantes & Temas em Pauta \\
\hline Genebra & 1947 & 23 & Tarifas \\
\hline Annecy & 1949 & 13 & Tarifas \\
\hline Torquay & $1950-1951$ & 38 & Tarifas \\
\hline Genebra & $1955-1956$ & 26 & Tarifas \\
\hline Dillon & $1960-1961$ & 26 & Tarifas \\
\hline Kennedy & $1964-1967$ & 62 & Tarifas e antidumping. \\
\hline Tóquio & $1973-1979$ & 102 & $\begin{array}{l}\text { Tarifas, Medidas não tarifárias, Cláusula de } \\
\text { Habilitação. }\end{array}$ \\
\hline Uruguai & $1986-1993$ & 123 & $\begin{array}{l}\text { Tarifas, Agricultura, Serviços, Propriedade } \\
\text { Intelectual, Medidas de Investimento, novo } \\
\text { marco jurídico, OMC. }\end{array}$ \\
\hline Doha & $2001-?$ & 149 & $\begin{array}{l}\text { Tarifas, Agricultura, Serviços, Facilitação de } \\
\text { Comércio, Solução de Controvérsias, "Regras". }\end{array}$ \\
\hline
\end{tabular}

Fonte: WTO, The GATT years: from Havana to Marrakesh. Disponível em <http://www.wto.org/english/thewto_e/whatis_e/tif_e/fact4_e.htm> Acesso em 07/05/2012.

Esse vácuo regulatório do comércio agrícola em nível multilateral foi viabilizado principalmente pela pressão exercida pelos PDs quando da assinatura do GATT, que passaram a externalizar preocupações referentes à preservação da segurança alimentar e da competitividade no campo. O colapso dos preços das commodities após a Grande Depressão de 1930 e o fim da Segunda Guerra Mundial (1939-1945) ajudaram a legitimar as posições maximalistas dos PDs, sobretudo dos $\mathrm{EUA}^{99}$, o que fez com que a agricultura passasse a ter um tratamento diferenciado no texto do GATT de 1947.

Dessa forma, a linguagem do Acordo, ao abrir exceções referentes à regulação de subsídios (domésticos e direcionados à exportação) e de restrições quantitativas no comércio

\footnotetext{
${ }^{99}$ Com a promulgação do Agricultural Adjustment Act, de 1938, os EUA ampliavam ainda mais sua política interna de subsídios à produção e à exportação, bem como a possibilidade de lançarem mãos de tarifas e restrições quantitativas para protegerem seus produtores agrícolas. Essa definição estratégica voltada ao protecionismo no âmbito interno já denotava a pouca disponibilidade do país de avançar na regulação do tema na área multilateral naquela época. ARAÚJO, Leandro Rocha de; LIMA, Rodrigo C.A.; JUNQUEIRA, Carla. Agricultura. In: THORSTENSEN, Vera; JANK, Marcos S (coord.). O Brasil e os grandes temas do comércio internacional. São Paulo, Lex Editora; Aduaneiras, 2005, p. 39. e CONGRESSIONAL RESEARCH SERVICE (CRS). Agriculture: A Glossary of Terms, Programs and Laws. Report for Congress , 2005 Disponível em https://opencrs.com Acesso em 06/05/2012.
} 
agrícola $^{100}$, passou a permitir que os países adotassem recorrentemente medidas prejudiciais ao fluxo comercial internacional, tais como: tarifas específicas, cotas tarifárias, impostos variáveis sobre as importações, medidas de preços mínimos de importação, apoio ao preço de mercado (market price support), barreiras não tarifárias mantidas por empresas estatais, entre outras $^{101}$.

Essas medidas tiveram consequências diretas no comércio agrícola internacional, uma vez que, por conta da aplicação de subsídios à produção e à exportação, os produtos de diversos países exportadores desenvolvidos passaram a gozar de uma competitividade artificial no mercado internacional. Essa dinâmica prejudicava (e ainda prejudica) os PEDs, que não tinham as mesmas condições de subsidiar sua produção interna e a exportação de determinados produtos. Além disso, a dificuldade de acesso a mercados (por meio de tarifas e barreiras não tarifárias) imposta, em sua grade maioria, pelos PDs era um fator impeditivo da possibilidade de algum tipo ação comercial que ainda restava aos mundo em desenvolvimento.

Essas [...] exceções acabaram, efetivamente, por afastar a agricultura da regulamentação geral estabelecida pelo GATT 1947, pois os países estavam aptos a subsidiar seus agricultores e a estabelecer proteção fronteiriça da forma como desejassem, e ainda a exportar o excesso consequentemente gerado, por meio de subsídios. Como essas proteções acabam por ocasionar um excesso de oferta, este somente era comercializado no mercado internacional por meio da utilização de elevados subsídios à exportação, o que acarretava instabilidade nos preços mundiais ${ }^{102}$.

As mudanças em termos de regulação aconteceram efetivamente quarenta anos depois, no âmbito da Rodada Uruguai (1986-1994), na qual ficou evidente que a consolidação de regras para a prática do comércio agrícola fazia-se necessária. Essa mudança do status quo regulatório ocorreu por diversas razões, dentre as quais destacam-se: (a) os altos custos até então gerados com o protecionismo agrícola, principalmente no que tange à guerra de subsídios entre EUA e UE; (b) os elevados déficits fiscais que se seguiram após o Choque do Petróleo na década de 1970; (c) a assinatura, durante a Rodada Tóquio (1973-1979), de

\footnotetext{
${ }^{100}$ WORLD TRADE ORGANIZATION (WTO). General Agreement on Tariffs and Trade (GATT 1947). The Legal Texts: The Results of the Uruguay Round of Multilateral Trade Negotiation. Cambridge, Reino Unido, Cambridge University Press, 2010. Para mais detalhes ver: Art. XVI:4, Art. XI:2 (a), (b) e (c) do GATT 47

${ }^{101}$ WORLD TRADE ORGANIZATION (WTO). The WTO Agreements Series: Agriculture. Genebra, Suiça, 2003 , p. 2.

${ }^{102}$ ARAÚJO, Leandro Rocha de; LIMA, Rodrigo C.A.; JUNQUEIRA, Carla. Agricultura. In: THORSTENSEN, Vera; JANK, Marcos S (coord.). O Brasil e os grandes temas do comércio internacional. São Paulo, Lex Editora; Aduaneiras, 2005, p. 39.
} 
acordos setoriais relacionados a bens agrícolas (Acordo de Bovinos e Lácteos), os quais mostravam a possibilidade de um mínimo de regulação plurilateral em importantes setores do campo; e (d) a pressão exercida pelo Grupo de CAIRNS ${ }^{103}$ durante as negociações da Rodada Uruguai para uma efetiva liberalização do comércio agrícola por meio da redução de tarifas e de subsídios internos ${ }^{104}$.

Em linhas gerais, o Acordo sobre Agricultura (AA), resultante da Rodada Uruguai, estabeleceu importantes diretrizes no comércio agrícola internacional que visavam a reduzir, progressivamente, as distorções presentes no mercado internacional. As alterações ocorreram em torno dos três pilares de negociação: acesso a mercados; apoio interno e competição nas exportações.

No que se refere ao acesso a mercados, ficou estabelecido que todas as barreiras não tarifárias deveriam ser transformadas em tarifas ad valorem, as quais sofreriam reduções posteriores (corte médio geral de 24\% para os PEDs e 36\% para os PDs e reduções mínimas por produto de $10 \%$ para os PEDs e $15 \%$ para os PDs). Além disso, foram estabelecidos níveis mínimos de acesso a mercado e um mecanismo de Salvaguarda Agrícola Especial (Special Safeguard Provision - SSP), de caráter transitório, diferente do Acordo de Salvaguardas da OMC. Por meio da SSP, os países poderiam lançar mão de impostos adicionais no ato da importação para proteger seu mercado interno, caso ocorra um surto importador de algum produto específico ou alguma queda abrupta no preço de uma commodity $^{105}$.

Em relação ao apoio interno, o principal aspecto regulatório ocorreu por meio da sistematização dos subsídios agrícolas de acordo com o seu grau de distorção e necessidade de redução. Para fins didáticos, convencionou-se alocar os subsídios em "caixas" de cores diferenciadas (amarela, azul e verde), embora no texto do acordo essa subdivisão não apareça.

A caixa amarela (art. 6 do AA) apresenta medidas internas extremamente prejudiciais ao comércio (Medidas Agregadas de Apoio ou Aggregate Measurement of Support - AMS) que sofreram limitações e compromissos globais de redução da ordem de $20 \%$ para os PDs e

\footnotetext{
${ }^{103}$ O Grupo de Cairns é formado por 19 países, dentre os quais destacam-se importantes exportadores de produtos agrícolas, como Brasil, Argentina e Austrália. O principal interesse dessa coalizão é o maior acesso a mercados para produtos dessa natureza. Fonte: OMC, Groups in the WTO, 2012. Disponível em <http://www.wto.org/english/tratop_e/dda_e/negotiating_groups_e.pdf> Acesso em 04/06/2012.

${ }^{104}$ HIGGOTT, Richard A., COOPER, Andrew F. Middle Power Leadership and Coalition Building: Australia, the Cairns Group, and the Uruguay Round of Trade Negotiations. International Organization, Vol. 44, $\mathrm{n}^{\circ} 4$, 1990, p.589-632.

${ }^{105}$ CEDRO, Rafael Rosa. Desenvolvimento Rural e a OMC: a experiência do Brasil. Curitiba: Juruá, 2011, p. 203.
} 
13\% para os PEDs. As medidas da caixa amarela abrangem políticas de preços mínimos; créditos subsidiados de custeio, investimento e comercialização; isenções fiscais; e pagamentos complementares.

As medidas presentes na caixa azul (art. 6.5 do AA) e na caixa verde (Anexo 2 do AA) ficaram isentas de redução, bem como os subsídios presentes na chamada caixa S\&D (art. 6.2 do AA, exclusiva para PEDs) e os suportes em pequena escala ou "de minimis" em nível geral e para produtos específicos (5\% do valor total produção - VTD - para PDs e 10\% do VTD para os PEDs, tanto no nível geral quanto para produtos específicos, estavam excluídos do cálculo de redução. ${ }^{106}$

Além disso, foram estabelecidas diretrizes importantes para a questão da competição às exportações, sobretudo no que tange aos subsídios à exportação, como a redução em seu valor total (na ordem de $36 \%$ para os PDs e $24 \%$ para os PEDs) e na quantidade de exportações beneficiadas (21\% para os PDs e $14 \%$ para os PEDs $)^{107}$.

Por fim, é importante destacar quatro decisões do AA: (a) os PMDRs ficaram isentos de qualquer tipo de redução, seja ela referente a subsídios ou tarifas; (b) o prazo para a implementação dos cortes em subsídios e tarifas era de seis anos para os PDs e dez anos para os PEDs; (c) foi estabelecida, no artigo XIII do AA (Due Restraint), a chamada cláusula da Paz, que restringia, pelo prazo de nove anos, o acionamento dos subsídios agrícolas perante o Órgão de Solução de Controvérsias (OSC) da OMC, além de restringir a adoção de medidas compensatórias; e por fim, (d) novas negociações, visando à continuidade da reforma regulatória no comércio agrícola internacional, deveriam ocorrer um ano antes do período de implementação, ou seja, no ano de 2000, conforme estabelecido pelo Artigo XX (Continuation of the Reform Process) do $\mathrm{AA}^{108}$.

\footnotetext{
${ }^{106}$ ARAÚJO, Leandro Rocha de; LIMA, Rodrigo C.A.; JUNQUEIRA, Carla. Agricultura. In: THORSTENSEN, Vera; JANK, Marcos S (coord.). O Brasil e os grandes temas do comércio internacional. São Paulo, Lex Editora; Aduaneiras, 2005, p. 46-47.

${ }_{107}$ GOYOS JUNIOR, Durval de Noronha. A OMC e os Tratados da Rodada Uruguai. São Paulo: Observador Legal, 1994, p.35-47.

${ }^{108}$ WORLD TRADE ORGANIZATION (WTO). Agreement on Agriculture. In: The Legal Texts: The Results of the Uruguay Round of Multilateral Trade Negotiation. Cambridge, Reino Unido, Cambridge University Press, 2010, p.33-58.
} 
Quadro 4 - Principais resultados (metas) da Rodada Uruguai no tema Agricultura

\begin{tabular}{|c|c|c|c|}
\hline Pilares da Negociação & Medidas & $\begin{array}{c}\text { Países Desenvolvidos } \\
\text { Membros }\end{array}$ & $\begin{array}{c}\text { Países em } \\
\text { Desenvolvimento } \\
\text { Membros } \\
\end{array}$ \\
\hline $\begin{array}{c}\text { Apoio Interno } \\
\text { (Subsídios) }\end{array}$ & $\begin{array}{c}\text { Cortes Totais no AMS para o setor } \\
\text { (Período Base: } 1986-88)\end{array}$ & $-20 \%$ & $-13 \%$ \\
\hline \multirow{2}{*}{$\begin{array}{c}\text { Acesso a Mercados } \\
\text { (Tarifas) }\end{array}$} & $\begin{array}{c}\text { Corte médio para o conjunto de } \\
\text { produtos agrícolas }\end{array}$ & $-36 \%$ & $-24 \%$ \\
\hline & Corte mínimo por produto & $-15 \%$ & $-10 \%$ \\
\hline \multirow{2}{*}{$\begin{array}{c}\text { Competição nas } \\
\text { Exportações } \\
\end{array}$} & Corte no valor dos subsídios & $-36 \%$ & $-24 \%$ \\
\hline & Corte nas quantidades subsidiadas & $-21 \%$ & $-14 \%$ \\
\hline $\begin{array}{c}\text { Tratamento Especial } \\
\text { e Diferenciado }\end{array}$ & Período de Implementação das Medidas & 6 anos $(1995-2000)$ & $10 \operatorname{anos}(1995-2005)$ \\
\hline
\end{tabular}

Fonte: CEDRO, Rafael Rosa. Desenvolvimento Rural e a OMC: a experiência do Brasil. Curitiba: Juruá, 2011, p. 121 e WORLD TRADE ORGANIZATION. Grupo de Negociação em Acesso a Mercados. Modalities for the Establishment of Specific Binding Commitments under the Reform Programme, 1993. (MTN.GNG/MA/W/24).

Apesar de parecer satisfatório, tendo em vista as diferentes faixas de redução de subsídios, tarifas e períodos de implementação das medidas em relação ao grau de desenvolvimento do países, o AA apresenta distorções estruturais que prejudicam o comércio até os dias atuais. Isso porque as grandes definições do Acordo, como período base para a referência de subsídios internos e à exportação, diretrizes da caixa azul, cláusula da paz, entre outras, foram estabelecidas em reuniões bilaterais entre Estados Unidos (EUA) e União Europeia (UE), as quais culminaram com o Acordo de Blair House, em que as diferenças entre a potência norte-americana e os países do Bloco Europeu foram acomodadas. Essa aproximação bilateral alterou profundamente o nível de ambição da liberalização agrícola na Rodada Uruguai, haja vista o elevado nível de subsídios aplicados na esfera doméstica por importantes players do comércio agrícola internacional, como se observa no Gráfico 1, a seguir. 


\section{Gráfico 1 - Apoio Interno notificado à OMC pela CE (UE), EUA e Japão}

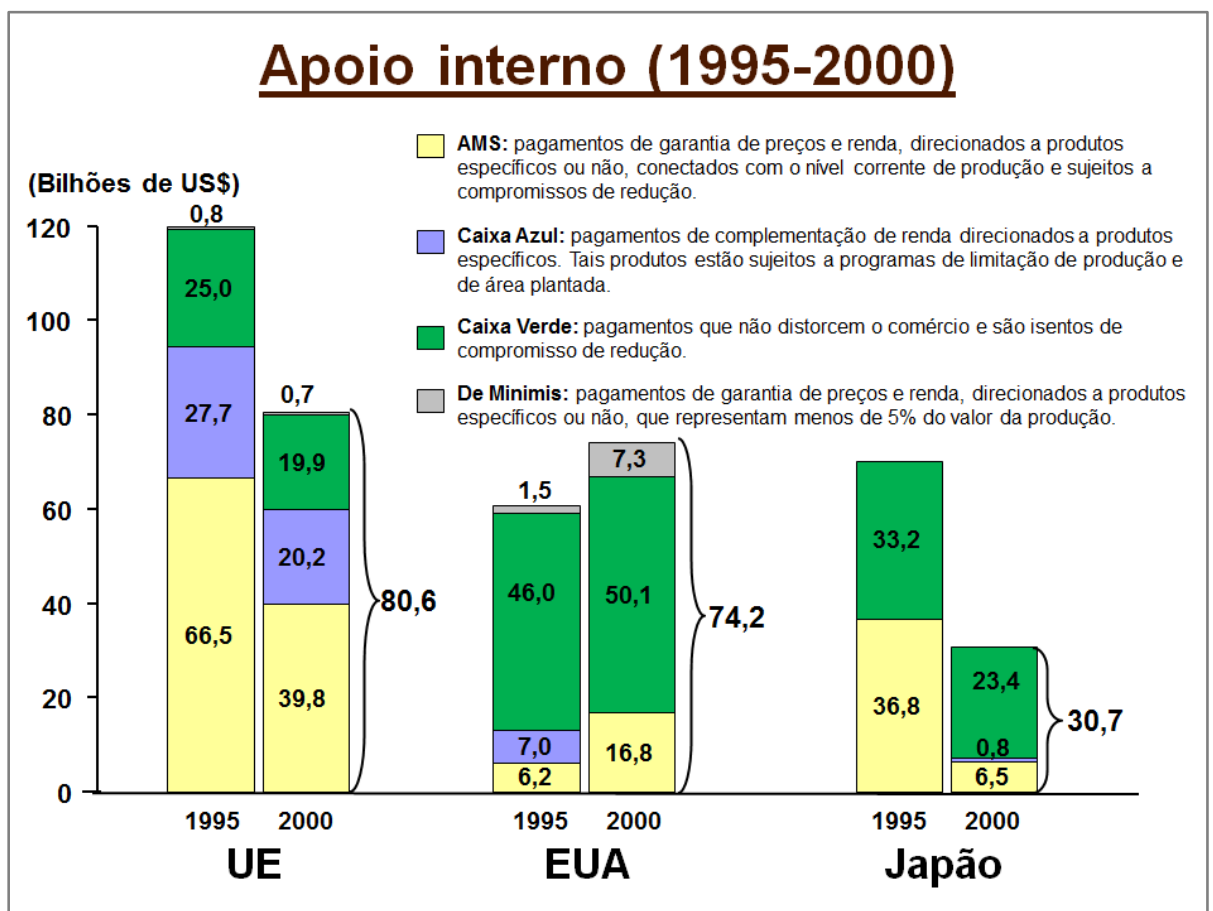

Fontes: Instituto de Estudo do Comércio e Negociações Internacionais (ICONE), com dados da OMC.

CEDRO, Rafael Rosa. Desenvolvimento Rural e a OMC: a experiência do Brasil. Curitiba: Juruá, 2011, p. 124 e ARAÚJO, Leandro Rocha de; LIMA, Rodrigo C.A.; JUNQUEIRA, Carla. Agricultura. In: THORSTENSEN, Vera; JANK, Marcos S (coord.). O Brasil e os grandes temas do comércio internacional. São Paulo, Lex Editora; Aduaneiras, 2005, p. 48.

Ademais, como mostra a Tabela 1, inúmeros picos tarifários foram mantidos por parte de importantes PDs, mesmo com a definição de redução tarifária ocorrida na Rodada Ururguai.

Tabela 1 - Barreiras às exportações brasileiras

\begin{tabular}{l|c|c|c}
\hline \multicolumn{1}{c|}{ Produto } & $\begin{array}{c}\text { Comunidade } \\
\text { Europeia }\end{array}$ & EUA & Japão \\
\hline Açucar Bruto & $160,8 \% *$ & $167 \% *$ & $154,3 \% *$ \\
Álcool & $46,7 \% *$ & $47,5 \% *$ & $83,3 \%$ \\
Leite em pó & $68,4 \% *$ & $49,1 \% *$ & $196,7 \% *$ \\
Frango em Cortes (congelado) & $94,5 \% *$ & $16,9 \% *$ & $11,9 \%$ \\
Carne Suína (congelada) & $50,6 \% *$ & $0,0 \%$ & $309,5 \% *$ \\
Carne Bovina (congelada) & $176,7 \% *$ & $26,4 \%$ & $50 \%$ \\
Milho & $84,9 \% *$ & $2,3 \% *$ & $95,4 \% *$ \\
Tabaco & $24,9 \% *$ & $350 \%$ & $0 \%$ \\
Suco de Laranja & $15,2 \%$ & $44,5 \% *$ & $21,4 \%$ \\
\hline
\end{tabular}

(*) Indicam que as tarifas específicas foram convertidas em seus equivalentes ad valorem

Fonte: ARAÚJO, Leandro Rocha de; LIMA, Rodrigo C.A.; JUNQUEIRA, Carla. Agricultura. In: THORSTENSEN, Vera; JANK, Marcos S (coord.). O Brasil e os grandes temas do comércio internacional. São Paulo, Lex Editora; Aduaneiras, 2005, p. 45. 
Como se pode perceber de acordo com Gráfico 1, o elevado teto de subsídios de caixa amarela, passível de redução gradual, acordado entre as grandes potências ao fim da Rodada Uruguai (Total AMS), tornou possível a continuidade da utilização de medidas de apoio interno prejudiciais ao comércio mesmo com assinatura do $\mathrm{AA}^{109}$.

Além disso, a ampla possibilidade de utilização, sem compromisso de redução, dos subsídios de caixa verde (que sempre teve os EUA como destacado usuário), azul e de minimis promoveu, ao longo do tempo, um fenômeno conhecido como box-shifting, em que houve a substituição gradual, por parte dos países, da utilização de subsídios proibidos por permitidos. Além do box-shifting, a regulação em torno de acesso a mercados permitiu a ocorrência de outro fenômeno, conhecido como product-shifting, por meio do qual diferentes estratégias de protecionismo (cotas tarifárias; SSP - amplamente utilizado pelos PDs; picos e escaladas tarifárias - ver tabela 1; tarifas específicas; entre outros) foram utilizadas para resguardar os interesses de produtores nacionais ${ }^{110}$. Vale salientar, por fim, a elevada base de compromisso de redução dos subsídios à exportação que a Suíça e a UE estabeleceram em 1995, da ordem de US\$ 450 milhões e US\$ 6 bilhões respectivamente ${ }^{111}$.

Conforme previa-se no artigo XX do AA, novas negociações visando à progressiva redução de medidas distorcivas ao comércio e ao aumento da liberalização do fluxo entre os países Membros iniciaram-se no de 2000. Todavia, por conta de diversas posições divergentes entre os países participantes, não houve avanço na área agrícola ${ }^{112}$. Um amplo e concreto mandato negociador seria visto somente no ano posterior, no âmbito da $4^{\mathrm{a}}$ Conferência Ministerial da OMC, em Doha no Catar, em que os países decidiram lançar bases para a ampliação da regulação em mais de dezoito áreas relativas ao comércio internacional.

\footnotetext{
${ }^{109}$ De acordo com a metodologia de cálculo para os compromissos de redução gradual de subsídios da caixa amarela (AMS), a UE deveria reduzir tais medidas partindo de uma base de US\$ 78 bilhões. Os EUA, por sua vez, deveriam reduzir seus subsídios de caixa amarela a partir de uma base de US\$24 bilhões. O Brasil, por fim, assumiu um compromisso de redução em uma base de US\$ 1bilhão. Mais detalhes em: WORLD TRADE ORGANIZATION. Sessão Especial do Comitê de Agricultura. Domestic Support: Background Paper by the Secretariat, 2000. G/AG/NG/S/1

${ }^{110}$ JALES, Mario; Jank Marcos. On Product, Box and Blame Shifting: Negotiating Frameworks for Agriculture in the WTO Doha Round. Integration and Trade, Vol. 9, nº 22, 2005, p. 68-70.

${ }^{111}$ WORLD TRADE ORGANIZATION. Sessão Especial do Comitê de Agricultura. Members' usage of domestic support categories export subsidies and export credits: Background Paper by the Secretariat, 2000. G/AG/NG/S/12.

112 ARAÚJO, Leandro Rocha de; LIMA, Rodrigo C.A.; JUNQUEIRA, Carla. Agricultura. In: THORSTENSEN, Vera; JANK, Marcos S (coord.). O Brasil e os grandes temas do comércio internacional. São Paulo, Lex Editora; Aduaneiras, 2005, p. 54.
} 


\subsection{A importância do tema agrícola para o Brasil}

O envolvimento do Brasil nas negociações do Sistema Multilateral de Comércio, sobretudo no tema agrícola durante a Rodada Uruguai e a Rodada Doha justificam-se por razões economicamente latentes. A primeira, e possivelmente a que mais se destaca, diz respeito à evolução do país como importante exportador de commodities no cenário internacional. A segunda, talvez menos conhecida no cenário internacional porém de fundamental importância econômica no âmbito interno, diz respeito à manutenção da Política de Desenvolvimento Rural Brasileira, que favorece milhões de pequenos e médios produtores que fazem parte da chamada agricultura familiar.

No que se refere às principais características do Brasil do agronegócio, destaca-se a participação da produção e exportação que o país detém em relação ao total produzido e comercializado no mundo dentre algumas commodities, como mostra a Tabela 2.

Tabela 2 - Produção e Exportação de produtos agrícolas - Brasil (\% do total Mundial)

\begin{tabular}{c|c|c|c|c}
\hline Produtos & $\begin{array}{c}\text { Produção } \\
\text { brasileira } \\
(2011)\end{array}$ & Posição & $\begin{array}{c}\text { Exportações } \\
\text { brasileiras } \\
(2011)\end{array}$ & Posição \\
\hline Laranja & $57 \%$ & $1^{\circ}$ & $81 \%$ & $1^{\circ}$ \\
Café & $37 \%$ & $1^{\circ}$ & $28 \%$ & $1^{\circ}$ \\
Grão de Soja & $28 \%$ & $2^{\circ}$ & $36 \%$ & $1^{\circ}$ \\
Carne Bovina & $15 \%$ & $1^{\circ}$ & $17 \%$ & $2^{\circ}$ \\
Carne de Frango & $16 \%$ & $2^{\circ}$ & $42 \%$ & $1^{\circ}$ \\
Carne Suína & $3 \%$ & $3^{\circ}$ & $8 \%$ & $3^{\circ}$ \\
Milho & $7 \%$ & $4^{\circ}$ & $9 \%$ & $4^{\circ}$ \\
Açucar & $21 \%$ & $1^{\text {o }}$ & $42 \%$ & $1^{\circ}$ \\
\hline
\end{tabular}

Fonte: Ministério da Fazenda e Ministério do Desenvolvimento, Indústria e Comércio

Exterior. Disponível em <www.mdic.gov.br > Acesso em 20/05/2012. Elaboração do autor.

Outro importante aspecto diz respeito à participação do agronegócio na balança comercial brasileira ao longo da última década, atividade que tem auxiliado sobremaneira o alcance de sucessivos superávits totais anuais, haja vista o crescimento exacerbado do déficit de produtos manufaturados no mesmo período, como mostra o Gráfico 2.

De acordos com dados do Ministério do Desenvolvimento Indústria e Comércio Exterior (MDIC), dentre os dez principais itens da pauta exportadora brasileira em 2011, que juntos somaram cerca de $50 \%$ do total exportado naquele ano, sete produtos são do 
agronegócio (soja em bruto, açúcar em bruto, café em grão, extratos do óleo de soja, carne de frango, carne bovina e açúcar refinado $)^{113}$.

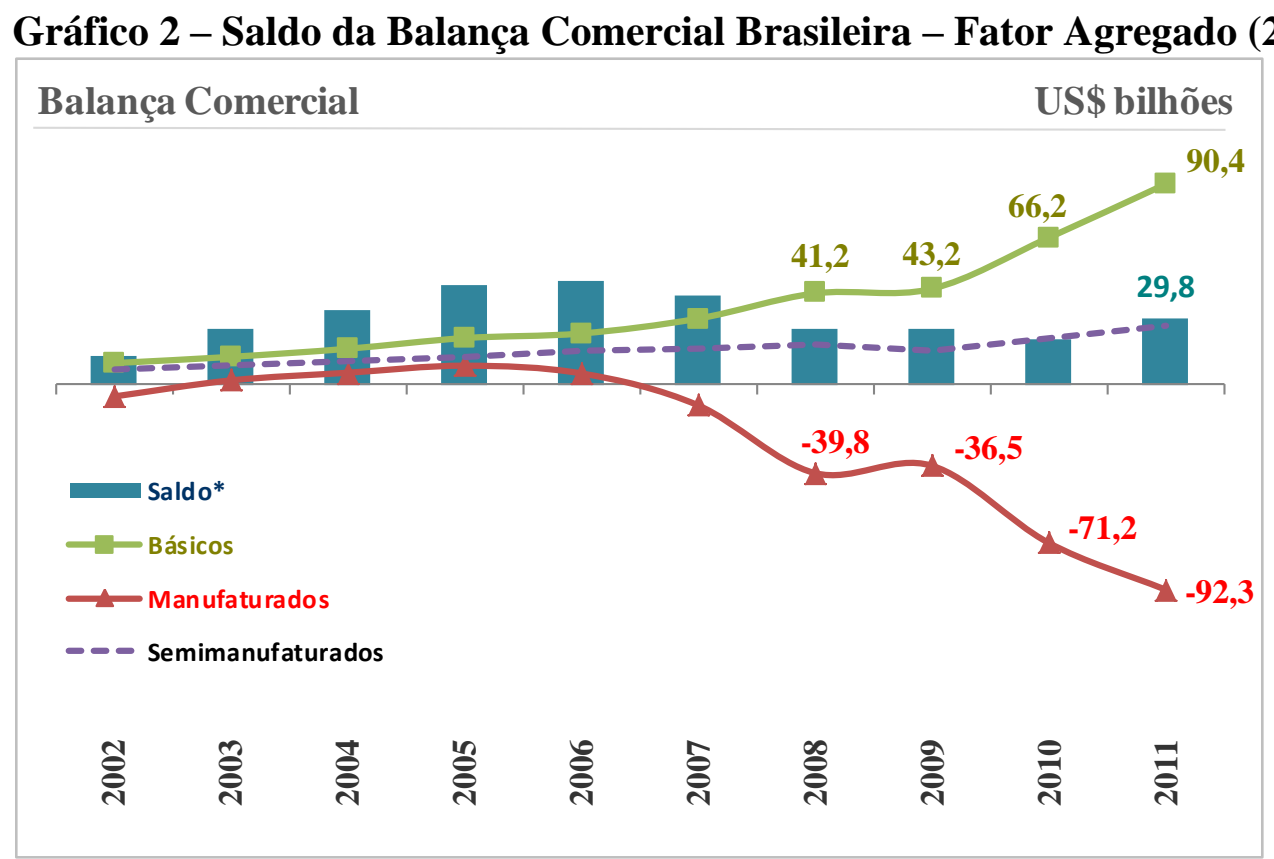

Fonte: Fundação Centro de Estudos do Comércio Exterior (FUNCEX).

Disponível em <www.funcex.com.br> Acesso em: 20/05/2012. Elaboração do autor.

Por fim, deve-se destacar a evolução do PIB do agronegócio brasileiro medido pelo Centro de Estudos Avançados em Economia Aplicada (CEPEA), conforme indica o Gráfico 3. De acordo com o Centro, desde 1994, o PIB do agronegócio apresentou um crescimento de cerca de $40 \%$, partindo de $\mathrm{R} \$ 648$ bilhões naquele ano e chegando à R \$ 918 bilhões em 2011, quando representou 22,5\% do PIB total brasileiro.

\footnotetext{
${ }^{113}$ Dados extraídos da base ALICEWEB, do Ministério do Desenvolvimento Indústria e Comércio Exterior
} (MDIC). Disponível em <http://aliceweb.desenvolvimento.gov.br/ > Acesso em 20/05/2012. 


\section{Gráfico 3 - Evolução do PIB do Agronegócio brasileiro}

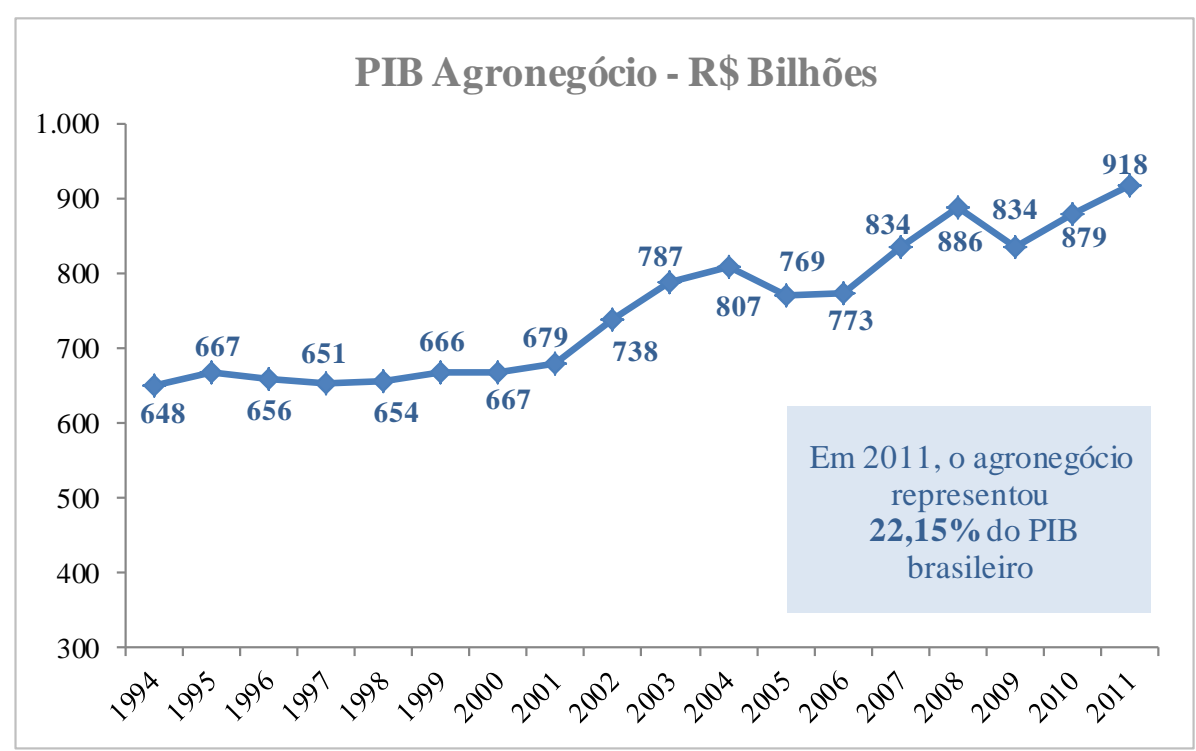

Fonte: Dados do CEPEA (Centro de Estudos Avançados em Economia Aplicada).

Disponível em <http://cepea.esalq.usp.br/pib/> Acesso em: 20/06/2012. Elaboração do autor.

O outro pilar que sustenta o engajamento do Brasil no processo de regulação do comércio agrícola em nível internacional diz respeito à vertente do país voltada para a manutenção da agricultura familiar, a qual, entre outros critérios, deve ter a direção dos trabalhos no estabelecimento exercida pelo próprio agricultor, e na qual o trabalho familiar deve ser superior ao trabalho contratado (Lei 11.326/2006) ${ }^{114}$.

Dados do Ministério do Desenvolvimento Agrário do Brasil (MDA) estimam que, atualmente, $70 \%$ do total de alimentos consumidos no país advêm da agricultura familiar ${ }^{115}$. De acordo com o Censo agropecuário 2006, elevados percentuais de produção nacional de diversos produtos da cesta básica brasileira advém da agricultura familiar, como: mandioca (87\%), feijão (70\%), milho (46\%), café (38\%), arroz (34\%), leite (58\%), plantel de suínos (59\%), plantel de aves $(30 \%)^{116}$.

Essa elevada produção justifica a relativa baixa importação de produtos básicos (categoria que abarca um grande número de alimentos) quando se observa a balança comercial dessa categoria, conforme indicado no Gráfico 4. As exportações de produtos básicos foi aproximadamente quatro vezes maior do que suas importações no ano de 2011.

\footnotetext{
${ }^{114}$ CEDRO, Rafael Rosa. Desenvolvimento Rural e a OMC: a experiência do Brasil. Curitiba: Juruá, 2011 , p. 28.

115 Fonte: Ministério do Desenvolvimento Agrário (MDA). Disponível em: <http://www.mda.gov.br/portal/saf/programas/Selo_da_A> Acesso em 20/05/2012.

${ }^{116}$ Instituto Brasileiro de Geografia e Estatística - IBGE. Censo Agropecuário 2006. Primeiros Resultados: Agricultura Familiar. Rio de Janeiro, 2006.
} 


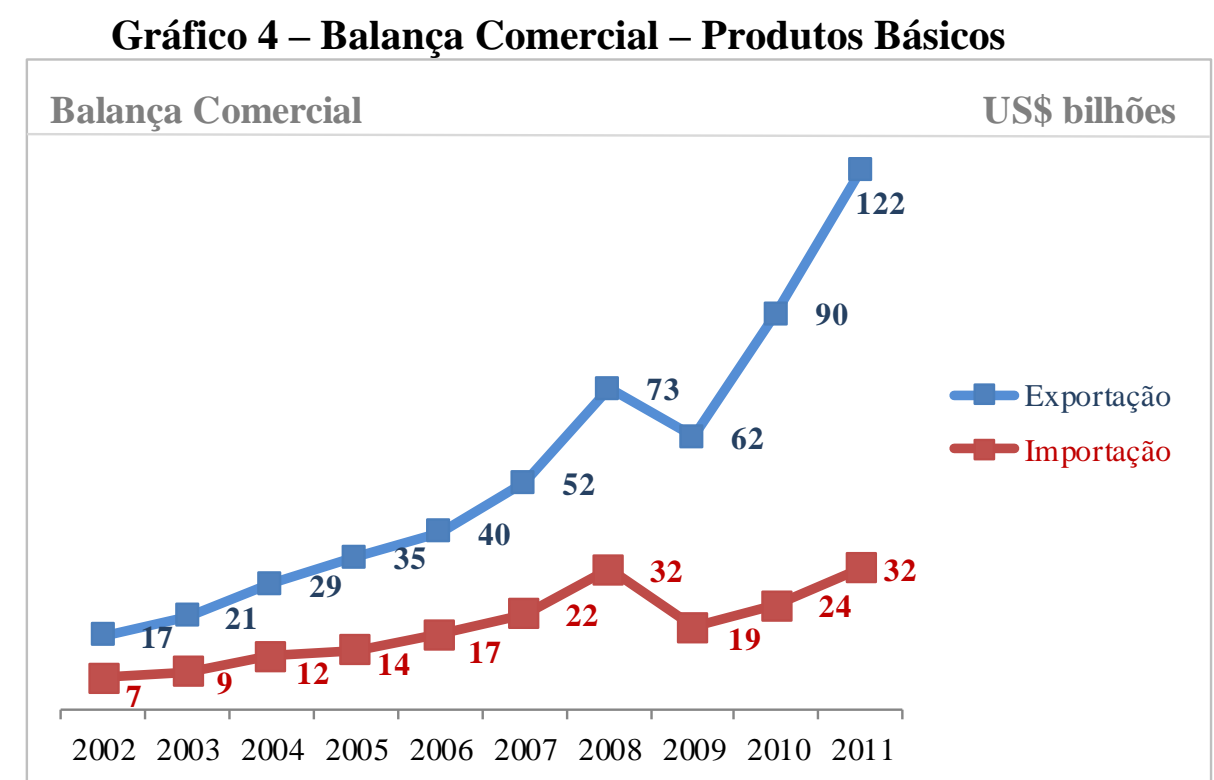

Fonte: Fundação Centro de Estudos do Comércio Exterior (FUNCEX).

Disponível em <www.funcex.com.br> Acesso em: 20/05/2012. Elaboração do autor.

Apesar de representarem somente $24 \%$ da área ocupada pelos estabelecimentos agropecuários brasileiros (o que demonstra eleva concentração agrária existente no país), a agricultura familiar representa $84 \%$ do total desses estabelecimentos, empregando um total de 12,3 milhões de pessoas (74,4\% do pessoal ocupado). Os estabelecimentos não familiares, por sua vez, ocupam 4,2 milhões de pessoas (25,6\% da mão de obra ocupada $)^{117}$.

A manutenção da elevada produtividade agrícola e a geração de empregos na agricultura familiar encontra bases em diversos programas governamentais voltados para o aperfeiçoamento da Política de Desenvolvimento Rural Brasileira. Um dos pilares dessa política foi a criação do MDA, em 1999, que supervisa o trabalho realizado pela Secretaria de Agricultura Familiar (SAF) e o Instituto Nacional de Colonização e Reforma Agrária (INCRA). No âmbito da SAF, estão os principais programas que fomentam o desenvolvimento da agricultura familiar no Brasil, com base em três eixos de ação ${ }^{118}$ :

a) Financiamento e Proteção da Produção Agrícola, composto pelo: Programa Nacional de Fortalecimento da Agricultura Familiar-Pronaf, que entre 2006 e 2009 desembolsou R \$ 35 bilhões em financiamentos; Programa de Garantia de Preços da Agriultura Familiar (PGPAF), que garante às famílias agricultoras que utilizam o crédito do Pronaf um desconto no pagamento do financiamento em caso de baixa de

\footnotetext{
${ }^{117}$ Instituto Brasileiro de Geografia e Estatística - IBGE. Censo Agropecuário 2006. Primeiros Resultados: Agricultura Familiar. Rio de Janeiro, 2006.

${ }^{118}$ Ministério do Desenvolvimento Agrário. Secretaria de Agricultura Familiar Disponível em http://comunidades.mda.gov.br/portal/saf/institucional/ Acesso em 02/06/2012.
} 
preços no mercado; Seguro da Agricultura Familiar (SEAF), que fornece segurança e relativa garantia de renda ao produtor rural ; Programa Garantia-Safra, específico para produtores de regiões que sofrem com perda de safra por motivo de seca ou excesso de chuvas.

b) Geração de Renda e Agregação de Valor: voltado a ações de: apoio à comercialização por meio de mecanismos que favorecem a aquisição direta de produtos de agricultores familiares ou de suas organizações pelo governo ou organizações; produção de biocombustíveis, por meio do qual o governo procura apoiar a participação da agricultura familiar na cadeia de produção desse tipo de combustível; diversificação econômica, voltadas a iniciativas da área de diversificação da produção e da renda familiar (a agroindústria familiar, o turismo e o artesanato).

c) Assistência Técnica de Extensão Rural: cujo principal objetivo define-se em termos de melhora da renda e da qualidade de vida das famílias rurais, por meio do aperfeiçoamento dos sistemas de produção, de mecanismo de acesso a recursos, serviços e renda, de forma sustentável.

Portanto, o desafio do Brasil, durante a Rodada Doha de Negociações, foi o de buscar alternativas que visassem não somente a políticas de incremento ao setor agroexportador, porém que também garantissem a manutenção das diversas iniciativas relacionadas à agricultura rural. Essa dualidade estratégica foi refletida em diversas propostas do G20 como se verá a seguir.

\subsection{Análise da atuação do G20 durante a Rodada Doha da OMC}

No intuito de contextualizar especificamente a atuação do Brasil no âmbito do G20, próximo subitem desse trabalho, faz-se necessária uma breve análise da atuação do Grupo entre 2003 e 2008, período em que as negociações se desenvolveram de forma mais latente e em que a coalizão se tornou um player fundamental durante o processo. Neste sentido, o presente subitem visa a ressaltar os principais momentos da Rodada com vistas à atuação do grupo, explorando de maneira ampla as questões técnicas e o ambiente político das principais etapas da negociação. ${ }^{119}$

\footnotetext{
${ }^{119}$ Para mais detalhes, ver: MISSÃO DO BRASIL EM GENEBRA, Carta de Genebra. Ministério das Relações Exteriores. 2003, 2004, 2005, 2006, 2007, 2008; GIORDANO DELGADO, Nelson; CAMPOLINA DE O.
} 
No intuito de elucidar a atuação da coalizão durante a Rodada, a presente análise terá como perspectiva dois fatores inerentes à dinâmica negociadora: o processo de tomada de decisão durante as Rodadas do GATT/OMC e os diferentes interesses em jogo presentes na esfera negociadora do Mandato de Doha.

Com relação ao processo de tomada de decisão, sabe-se que, mesmo a OMC contando com uma estrutura institucional aperfeiçoada e com crescente amplitude normativa, o contexto negociador das Rodadas, organizado de maneira informal ${ }^{120}$ desde a era GATT, permite que o poder político e econômico dos países sejam elementos centrais na formatação de regras nas mais diversas áreas. De forma geral, por meio de estratégias múltiplas de barganha, ora baseadas na lei ora baseadas no poder, os países interagem no espaço negociador da organização, visando a gerar benefícios teoricamente equitativos a todas as Partes (Pareto Improvement). Essa busca por resultados equitativos seria, em tese, ratificada pelo princípio de soberania igualitária entre os membros, o qual sugere que todas as decisões sejam tomadas, na prática, por consenso. No entanto, sabe-se que essa estrutura favorece a pressão dos estados mais fortes sobre os mais fracos, que, geralmente acabam cedendo aos interesses dos primeiros $^{121}$.

The GATT/WTO consensus decision-making process is organized hypocrisy in the procedural context. Sociologists and political scientists have recently identified hypocrisy as patterns of behavior or action that are decoupled from rules, norms, scripts, or rituals that are maintained for external display. ${ }^{122}$

Países desenvolvidos se utilizam de táticas como os side-payments ou package deals (variações de contratos assimétricos firmados com os países menos desenvolvidos) em diferentes momentos da negociação (lançamento da Rodada, formação da agenda e fechamento), fazendo com que seus interesses sejam de alguma forma atendidos, como se viu

SOARES, Adriano. G20: Origem, Evolução, Significado e Perspectivas. Latin American Trade Network. Working Paper. Buenos Aires, Facultad Latinoamericana de Ciencias Sociales (FLACSO). nº89, fev. 2008. Disponivel em http://www.latn.org.ar/wp-content/uploads/2012/03/wp-89-Delgado-Soares-Portugues.pdf Acesso em 02/07/2012; AREIAS, Ana Carolina. Os limites da Cooperação: O Brasil e o G-20 nas negociações agrícolas da Organização Mundial do Comércio. Rio de Janeiro, 2010. Dissertação de Mestrado - Instituto de Relações Internacionais, Pontifícia Universidade Católica do Rio de Janeiro; WORLD TRADE ORGANIZATION (WTO). Declaração Ministerial. Conferência Ministerial, 4 ${ }^{\mathrm{a}}$ Sessão, 20/11/2001. WT/MIN(01)/DEC/1; WTO. Doha Work Programme, 02/08/2004, WT/L/579; WTO. Declaração Ministerial. Conferência Ministerial, $6{ }^{\text {a }}$ Sessão, 22/12/2005. WT/MIN (05)/DEC; WTO. Sessão Especial do Comitê de Agricultura. Revised Draft Modalities for Agriculture. 06/12/2008. TN/AG/W/4/Rev.4

${ }^{120}$ NARLIKAR, Amrita, A Theory of Bargaining Coalitions in the WTO. Em NARLIKAR, Amrita; VICKERS, Brendan (eds.). Leadership and Change in the Multilateral Trading System. Republic of Letters Publishing, 2009, p. 185.

${ }^{121}$ STEINBERG, Richard H. "In the Shadow of Law or Power? Consensus-Based Bargaining and Outcomes in the GATT/WTO”. International Organization, vol. 56, n. 2, Spring 2002.

122 Idem, p. 342. 
anteriormente na consolidação do Acordo sobre Agricultura durante a Rodada Uruguai, que permitiu e ainda permite que EUA e UE mantenham práticas distorcivas ao comércio internacional (subsídios domésticos e à exportação, picos tarifários, entre outros) até os dias atuais.

Mesmo com o lançamento da Rodada Doha de Desenvolvimento, em 2001, no âmbito da IV Conferencia Ministerial da OMC, a dualidade de interesses entre PDs e PEDs ainda fazia-se presente, uma vez que os primeiros almejavam ampliar a regulação em áreas como investimentos, concorrência, facilitação de comércio, compras governamentais (Temas de Cingapura); e os PEDs ainda buscavam avançar na reforma de temas como agricultura, visando à redução dos subsídios internos e à exportação dos PDs, bem como medidas com impactos diretos no desenvolvimento rural e segurança alimentar em geral ${ }^{123}$. Sobre este tema, é importante destacar que as negociações visando à reforma da regulação agrícola respeitaram o prazo determinado no Artigo XX do AA, estabelecido na Rodada Uruguai, e tiveram início no ano $2000^{124}$, principalmente por conta do ativismo e pressão dos membros em desenvolvimento.

Essa dinâmica reflete o importante fato de que, antes do lançamento da Rodada, diversos PEDs passaram a ampliar sua capacidade de articulação política e técnica, no intuito de terem seus interesses representados com mais legitimidade e eficácia na arena de negociações ${ }^{125}$. Para o Brasil, o incremento da regulação agrícola no plano multilateral era, como já visto anteriormente, de fundamental importância econômica, fato que levou o país a se preparar, praticamente desde o término da Rodada Uruguai, para a continuação do processo de liberalização e a apoiar a proposta de lançamento de uma nova rodada de negociações comerciais multilaterais apresentada pela primeira vez em $1998^{126}$.

Sendo assim, a despeito de todas as assimetrias econômicas e interesses políticos conflitantes, a Rodada foi lançada e contava com um amplo mandato negociador e data final

123 CLAPP, Jennifer. WTO Agriculture Negotiations: Implications for the Global South. Third World Quartely, Vol. 27, nº 4, 2006. p. 566.

${ }^{124}$ PRESSER, Mário Ferreira; MADUREIRA, Frederico Quaresma, LENK, Wolfgang. Negociações em Agricultura na OMC. Revista Economia Política Internacional: Análise Estratégica. $\mathrm{n}^{\circ} 1 \mathrm{Julho/Setembro,}$ 2004. Instituto de Economia - UNICAMP. Disponível em: http://www.eco.unicamp.br/aspscripts/boletim_ceri/boletim/boletim1/editorial.pdf Acesso em 20/05/2012.

${ }^{125}$ PÁDUA LIMA, Maria Lucia L. M. Brazil's Multilateral Trade Diplomacy in the WTO. Em NARLIKAR, Amrita; VICKERS, Brendan (eds.). Leadership and Change in the Multilateral Trading System. Republic of Letters Publishing, 2009, p. 80.

${ }^{126}$ MISSÃO DO BRASIL EM GENEBRA, Carta de Genebra. Ministério das Relações Exteriores. Ano 4, n. ${ }^{\circ}$ 6, setembro de 2005, p.5. 
de conclusão em $1^{\circ}$ de janeiro de 2005 , o que, como se sabe, não foi respeitado. Os resultados deveriam ser consolidados e adotados de maneira única (single undertaking) e, mesmo com as diversas formas de interação entre os países ${ }^{127}$, as negociações deveriam ser dotadas de transparência e o princípio do tratamento especial e diferenciado para PEDs e PMDRs ${ }^{128}$ seria parte integral do processo ${ }^{129}$.

Por fim, o processo negociador seria conduzido pelo Comitê de Negociações Comerciais (CNC), que deveria reportar os resultados da dinâmica negociadora ao Conselho Geral (CG). No âmbito do CNC, foram estruturadas as Sessões Especiais, relacionadas a diversas áreas e com diversos comitês, bem como os Grupos de Negociação em acesso a mercados, regras e facilitação de comércio. A Figura 1 indica o quadro básico de negociação da Rodada Doha.

Figura 1 - Estrutura Básica de Negociações da Rodada Doha da OMC

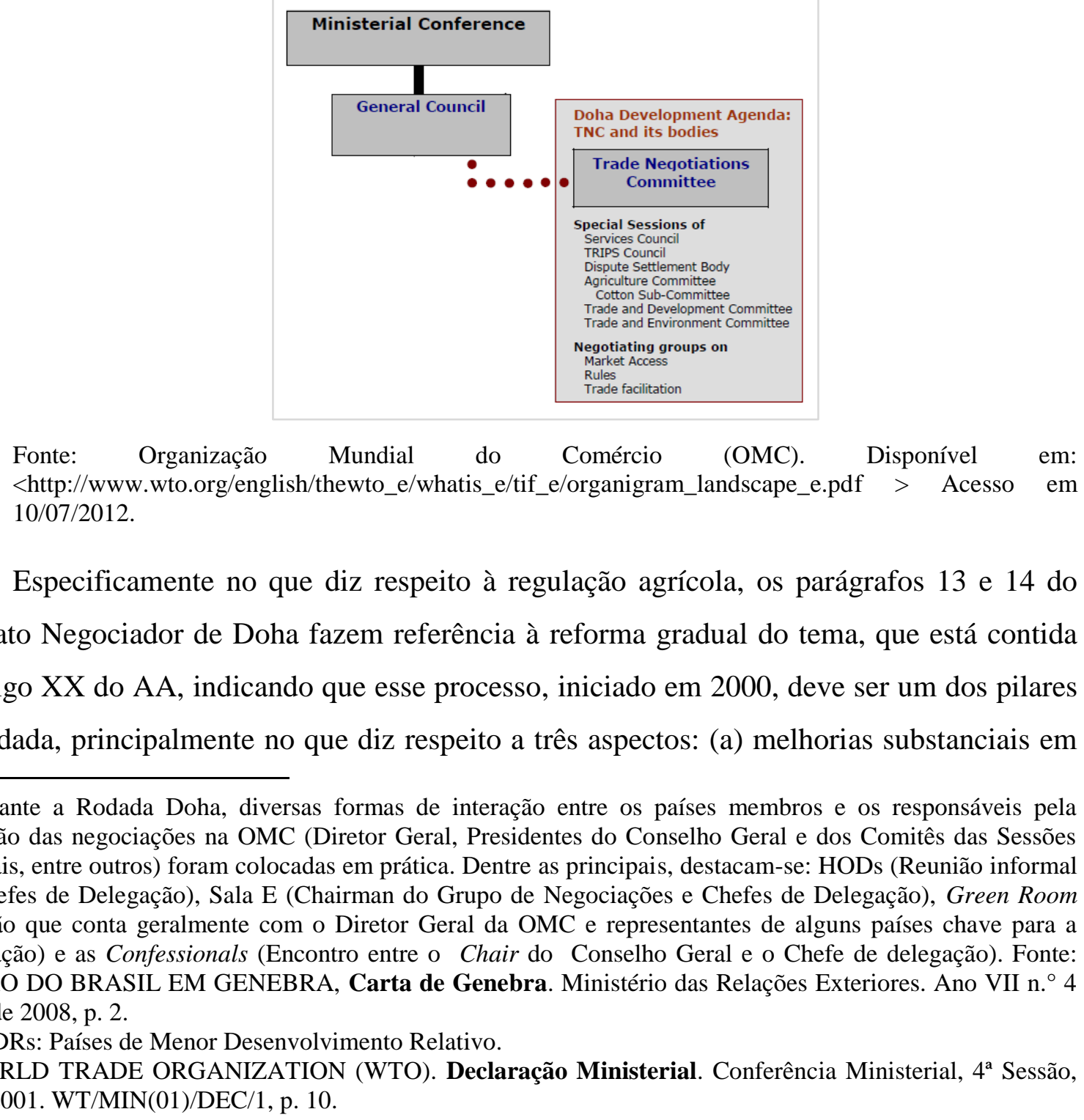

\footnotetext{
27 Durante a Rodada Doha, diversas formas de interação entre os países membros e os responsáveis pela condução das negociações na OMC (Diretor Geral, Presidentes do Conselho Geral e dos Comitês das Sessões Especiais, entre outros) foram colocadas em prática. Dentre as principais, destacam-se: HODs (Reunião informal dos Chefes de Delegação), Sala E (Chairman do Grupo de Negociações e Chefes de Delegação), Green Room (Reunião que conta geralmente com o Diretor Geral da OMC e representantes de alguns países chave para a negociação) e as Confessionals (Encontro entre o Chair do Conselho Geral e o Chefe de delegação). Fonte: MISSÃO DO BRASIL EM GENEBRA, Carta de Genebra. Ministério das Relações Exteriores. Ano VII n. ${ }^{\circ} 4$ Junho de 2008, p. 2.

${ }^{128}$ PMDRs: Países de Menor Desenvolvimento Relativo.

${ }^{129}$ WORLD TRADE ORGANIZATION (WTO). Declaração Ministerial. Conferência Ministerial, $4^{\mathrm{a}}$ Sessão, 20/11/2001. WT/MIN(01)/DEC/1, p. 10.
} 
acesso a mercados; (b) redução, com vistas à eliminação progressiva de todas as formas de subsídios à exportação e, por fim, (c) reduções substanciais de medidas de apoio doméstico distorcivas ao comércio internacional. As modalidades (parâmetros pelos quais devem ser negociados o compromisso final) entre os membros deveriam, segundo o parágrafo 14 do mandato negociador de Doha, ser estabelecidas até março de 2003, prazo que também não foi respeitado $^{130 .}$

Em relação às melhorias em acesso a mercados, os principais aspectos da negociação até 2008 relacionaram-se à consolidação de uma fórmula de redução tarifária, diminuição dos picos e escaladas tarifárias, criação ou expansão de cotas, eliminação das salvaguardas especiais para PDs, criação de um mecanismo de salvaguardas especiais para PEDs (SSM) e definição de um tratamento diferenciado a produtos especiais, que não deveriam receber cortes em suas tarifas.

No que tange à questão dos subsídios à exportação, a prevalência do componente político na tomada de decisão era notória, sobretudo no que dizia respeito à definição de uma data crível para a eliminação desse tipo de apoio. Um fator técnico inerente ao tema dizia respeito à amplitude da eliminação desses subsídios (conceito que ficou conhecido como paralelismo), de maneira que o acordo deveria assegurar que os diversos componentes dessas políticas (créditos à exportação, ajuda alimentar e atuação das empresas estatais de comércio) fossem eliminados conjuntamente.

Em relação ao apoio doméstico, estava em jogo o estabelecimento de cortes dos montantes destinados aos produtores rurais dos PDs e PEDs, bem como o aumento da disciplina nas caixas de subsídios (amarela, azul e verde), evitando que os países apenas reclassificassem e realocassem (em diferentes caixas) o tipo de subsídio concedido ao produtor, sem haver, contudo, um corte efetivo no apoio. Nesse sentido, as discussões ao longo da Rodada giravam em torno do estabelecimento de limites de uso para a caixa azul, cortes substantivos para a caixa amarela (a mais distorciva) e reforço das regras da caixa $\operatorname{verde}^{131}$.

\footnotetext{
${ }^{130}$ WORLD TRADE ORGANIZATION (WTO). Declaração Ministerial. Conferência Ministerial, $4^{\text {a }}$ Sessão, 20/11/2001. WT/MIN(01)/DEC/1, p.3

${ }^{131}$ MISSÃO DO BRASIL EM GENEBRA, Carta de Genebra. Ministério das Relações Exteriores. Ano 3, No. 3, Junho de 2004, p.6.
} 
Apesar de o mandato estabelecer, em 2001, quais seriam as regras do jogo a serem alteradas, os primeiros anos de negociação não apresentaram avanços concretos que refletissem o documento assinado em Doha, sobretudo por parte dos dois principais players, EUA e UE. A inação na arena multilateral aliada a ações protecionistas no âmbito interno desses dois players foram gradualmente deixando claro que o primeiro deadline para o cumprimento das modalidades em agricultura (março de 2003) seria perdido. Segundo o Embaixador do Brasil na OMC à época, Sr. Luis Felipe Seixas Correa:

No início de 2003, a impossibilidade de alcançar um acordo sobre modalidades para as negociações agrícolas, previsto em Doha para o final de março daquele ano, gerou a primeira crise da Rodada, e o primeiro grande desafio ao cumprimento dos objetivos negociadores estabelecidos no mandato. Dois fatores principais influíram para tanto: i) o atraso na reforma da PAC [Política Agrícola Comum], seu caráter parcial, menos profundo do que as expectativas geradas pelo próprio mandato de Doha e pelas ambições originais da Comissão; e ii) o retrocesso configurado pela Farm Bill, de 2002, que situou os EUA como grande país subsidiador. Uma perversa coincidência de interesses entre os dois principais responsáveis pelas distorções da agricultura mundial instalou-se no processo, passando a impedir o alcance dos objetivos do mandato negociador em relação à redução do apoio doméstico e aos subsídios à exportação ${ }^{132}$.

O corolário do protecionismo agrícola em nível doméstico de ambos os players ganhou espaço, no âmbito multilateral, em 13 de agosto de 2003, por meio de uma proposta (Framework) conjunta (JOB(03)/157), que acomodava as diferenças entre EUA e UE e diminuía sobremaneira as ambições do mandato negociador nos três pilares essenciais à reforma agrícola. Entre outras proposições, o documento conjunto previa: a continuação dos subsídios à exportação, a manutenção da caixa azul, ausência regulatória da caixa verde, uma fórmula de redução tarifária que não refletia as particularidades dos PEDs, a tentativa de criar uma divisão entre os PEDs ao criar uma nova categoria de países (Net Food Exporting Countries) ${ }^{133}$.

Essa tentativa de repetição do Acordo de Blair House às vésperas de uma Conferência Ministerial foi o principal fato gerador para a ação coordenada do mundo em desenvolvimento contra a manutenção do assimétrico padrão de negociação característico do SMC. Alguns PEDs, entre eles o Brasil, ao entenderem que não poderia haver espaço para a repetição dessa dinâmica negociadora, lançaram mão de uma estratégia conjunta de ação, por

\footnotetext{
${ }^{132}$ MISS ÃO DO BRASIL EM GENEBRA, Carta de Genebra. Ministério das Relações Exteriores. Ano 4, n. ${ }^{\circ}$ 6, setembro de 2005, p.2.

${ }^{133}$ WORLD TRADE ORGANIZATION (WTO). Documento Conjunto CE-EUA em Agricultura 13/08/2003. JOB(03)/157. Em MISSÃO DO BRASIL EM GENEBRA, Carta de Genebra. Ministério das Relações Exteriores. Ano 2, No. 6, de Setembro 2003, p.3-4 e AREIAS, Ana Carolina, op. cit. p. 95-96.
} 
meio da criação e manutenção de coalizões negociadoras, as quais seriam porta-vozes do interesse tanto do mundo em desenvolvimento quanto dos PMDRs.

A coalizão incumbida de contrapropor o documento conjunto EUA-UE e a proposta de texto do então presidente do Conselho Geral da OMC foi o $\mathrm{G} 20^{134}$, inicialmente idealizado pela delegação brasileira e que contou, à época, com a adesão de importantes PEDs, como Índia, China África do Sul e Argentina. Com isso, sete dias após o lançamento da proposta de EUA e UE, o G20 apresentou um robusto documento (JOB(03)/162, que procurava manter o nível de ambição acordado em Doha em termos de liberalização comercial e respeito ao princípio de tratamento especial e diferenciado aos PEDs e PMDRs.

De maneira geral, o Framework proposto em 2003 pelo G20 abarcava os três pilares da negociação agrícola e sugeria: a eliminação da caixa azul de subsídios; um corte nos subsídios da caixa amarela; uma maior regulação aos da caixa verde; a eliminação do mecanismo de salvaguarda especial para PDs; a criação de um mecanismo de salvaguarda para PEDs e de outro que identificasse produtos especiais que sofreriam menor redução tarifária, com direito à tratamento especial e diferenciado para PEDs e PMDRs; e, por fim, um parágrafo que propunha a eliminação completa dos subsídios à exportação ${ }^{135}$.

Apesar de o desfecho prematuro da V Conferência Ministerial em Cancun ter ocorrido por conta do embate entre PDs e PEDs quanto à perspectiva de regulação dos Temas de Cingapura, a Conferência foi marcada pela ação do G20 na área agrícola, a qual instituiu uma nova dinâmica negociadora na Rodada, abrindo caminho para que outros grupos de PEDs agissem conjuntamente em prol de seus interesses, como é o caso do G33 (que contava com diversos membros do G20 com posição mais defensiva na esfera agrícola), o Grupo Africano, o Grupo África-Caribe-Pacífico (ACP), o Grupo de Economias Pequenas e Vulneráveis (SVE, em inglês) e os já citados PMDRs ${ }^{136}$.

\footnotetext{
${ }^{134}$ O G20 é composto por: Argentina, Bolívia, Brasil, Chile, China, Cuba, Equador, Egito, Guatemala, India, Indonésia, México, Nigéria, Paquistão, Paraguai, Peru, Filipinas, África do Sul, Tanzânia, Tailândia, Uruguai, Venezuela e Zimbábue. Fonte: OMC, Groups in the WTO, 2012. Disponível em http://www.wto.org/english/tratop_e/dda_e/negotiating_groups_e.pdf Acesso em 04/06/2012.

${ }^{135}$ WORLD TRADE ORGANIZATION (WTO). Documento do G20 em Agricultura 20/08/2003. JOB(03)/162. Em MISSÃO DO BRASIL EM GENEBRA, Carta de Genebra. Ministério das Relações Exteriores. Ano 2, No. 6, de Setembro 2003, p.6-8 e GIORDANO DELGADO, Nelson; CAMPOLINA DE O. SOARES, Adriano. G20: Origem, Evolução, Significado e Perspectivas. Latin American Trade Network. Working Paper. Buenos Aires, Facultad Latinoamericana de Ciencias Sociales (FLACSO). nº89, fev. 2008. Disponivel em http://www.latn.org.ar/wp-content/uploads/2012/03/wp-89-Delgado-Soares-Portugues.pdf Acesso em 02/07/2012, p. 4-6.

${ }^{136}$ DÂMICO, Flavio S. O G-20 e as negociações agrícolas da OMC. Pontes, Vol. 3, n³ 3, 2007. Disponível em http://ictsd.org/i/news/12473/ Acesso em 20/06/2012. Para uma abordagem mais profunda da composição e dos
} 
The G20 proposal sought to preserve the level of ambition enjoined by Doha's original mandate. This new bargaining coalition managed to successfully aggregate countries at relatively lower levels of development in a real conciliatory effort with developed countries. It could be said that the G20 found a way to clearly express the objectives of participating countries and demonstrate way to accommodate other interests present in multilateral trading system. In short, it was a strong, yet constructive position ${ }^{137}$.

A partir de então, o Grupo passou a trabalhar continuamente, promovendo reuniões ministeriais contínuas e realizando pronunciamentos e propostas que muitas vezes norteavam o debate em torno da regulação agrícola durante as negociações, conforme mostram os Quadros 5 e 6 abaixo. Além disso, afastou-se gradativamente da postura extremamente ofensiva em agricultura defendida pelo Grupo de CAIRNS e passou a propugnar em seus documentos elementos que buscavam atender tanto aos interesses de países com postura ofensiva (Argentina, Uruguai, Brasil) quanto defensiva (Índia, China, diversos países da África) em termos de regulação agrícola.

A força do G-20 baseia-se em dois pilares: seu objetivo de integrar plenamente a agricultura em um sistema multilateral de comércio justo e fundado em regras; e sua capacidade de conciliar interesses agrícolas divergentes dentro do próprio grupo. Esses dois pilares outorgaram ao G-20 credibilidade sem precedente e evidenciaram que é possível encontrar um meio termo nas negociações quando há honestidade nos propósitos e probidade na abordagem. ${ }^{138}$

interesses dessas coalizões, ver: OMC, Groups in the WTO, 2012. Disponível em http://www.wto.org/english/tratop_e/dda_e/negotiating_groups_e.pdf Acesso em 04/06/2012.

${ }_{137}$ PÁDUA LIMA, Maria Lucia L. M. Brazil's Multilateral Trade Diplomacy in the WTO. Em NARLIKAR, Amrita; VICKERS, Brendan (eds.). Leadership and Change in the Multilateral Trading System. Republic of Letters Publishing, 2009, p. 75-95. 83.

${ }^{138}$ Kamal Nath, à época, Ministro do Comércio e Indústria da Índia. MINISTÉRIO DAS RELAÇÕES EXTERIORES. G-20 e a OMC: Comunicados e Documentos. Brasília, DF. Fundação Alexandre de Gusmão, 2007, p. 15. 
Quadro 5 - Principais propostas do G20 durante a negociação agrícola da Rodada Doha (2003-2008)

\begin{tabular}{|c|c|}
\hline DATA & PROPOSTA \\
\hline set/03 & AGRICULTURE - FRAMEWORK PROPOSAL (JOB(03)162) \\
\hline mai/04 & $\begin{array}{l}\text { G-20 PROPOSAL ON A FRAMEWORK FOR ESTABLISHING MODALITIES IN AGRICULTURE: MARKET } \\
\text { ACCESS }\end{array}$ \\
\hline jun/05 & G-20 PROPOSAL - REVIEW AND CLARIFICATION OF GREEN BOX CRITERIA \\
\hline $\mathrm{ju} 1 / 05$ & G-20 DRAFT ELEMENTS FOR DISCUSSION ON DOMESTIC SUPPORT: REDUCTION IN AMS \\
\hline jul/05 & G-20 DRAFT ELEMENTS FOR DISCUSSION BLUE BOX \\
\hline $\mathrm{jul} / 05$ & G-20 PROPOSAL - ELEMENTS FOR DISCUSSION ON MARKET ACCESS \\
\hline out/05 & G-20 PROPOSAL FOR THE ESTABLISHMENT OF PRODUCT-SPECIFIC CAPS IN AMS. \\
\hline out/05 & G-20 - ARTICLE 12.1 - EXPORT PROHIBITIONS AND RESTRICTIONS (PARAGRAPH 50) \\
\hline out/05 & $\begin{array}{l}\text { G-20 - MAINTAINING THE SPECIAL STATUS OF EXPORTING STEs (STATE TRADING ENTERPRISES) IN } \\
\text { DEVELOPING COUNTRIES }\end{array}$ \\
\hline out/05 & G20 PROPOSAL ON DOMESTIC SUPPORT \\
\hline out/05 & G-20 PROPOSAL ON MARKET ACCESS \\
\hline out/05 & $\begin{array}{l}\text { SOME GUIDELINES FOR TROPICAL AND PRODUCTS OF PARTICULAR IMPORTANCE TO THE } \\
\text { DIVERSIFICATION OF PRODUCTION FROM GROWING OF ILLICIT NARCOTIC CROPS }\end{array}$ \\
\hline out/05 & G-20 PROPOSAL ON SENSITIVE PRODUCTS: SELECTION AND TREATMENT \\
\hline out/05 & IMPROVING MONITORING AND SURVEILLANCE MECHANISMS \\
\hline jun/07 & IMPROVING MONITORING AND SURVEILLANCE MECHANISMS \\
\hline $\operatorname{dez} / 07$ & $\begin{array}{c}\text { G-20 DRAFTING SUGGESTIONS TO THE REVISED DRAFT MODALITIES ON AGRICULTURE TN/AG/W/4 ON } \\
\text { DOMESTIC SUPPORT (JOB(07)/218) }\end{array}$ \\
\hline dez/07 & G-20 SUBMISSION TARIFF CAPPING (JOB(07)/219) \\
\hline dez/07 & G-20 SUBMISSION GUIDELINES FOR MODALITIES IN TARIFF SIMPLIFICATION (JOB(07)/220) \\
\hline $\operatorname{dez} / 07$ & $\begin{array}{l}\text { G-20 SUBMISSION MODALITIES FOR EXPORT COMPETITION: EXPORT CREDITS, EXPORT CREDITS } \\
\text { GARANTEES OR INSURANCE PROGRAMMES (JOB(07)/221) }\end{array}$ \\
\hline dez/07 & G-20 SUBMISSION GUIDELINES FOR MODALITIES IN TARIFF ESCALATION (JOB(07)/222) \\
\hline $\mathrm{dez} / 07$ & $\begin{array}{l}\text { G-20 SUBMISSION GUIDELINES FOR MODALITIES SENSITIVE PRODUCTS IN DEVELOPED COUNTRIES } \\
(\mathrm{JOB}(07) / 223)\end{array}$ \\
\hline
\end{tabular}

Fonte: MINISTÉRIO DAS RELAÇÕES EXTERIORES. G-20 e a OMC: Comunicados e Documentos. Brasília, DF. Fundação Alexandre de Gusmão, 2007 e MISSÃO DO BRASIL EM GENEBRA, Carta de Genebra. Ministério das Relações Exteriores.

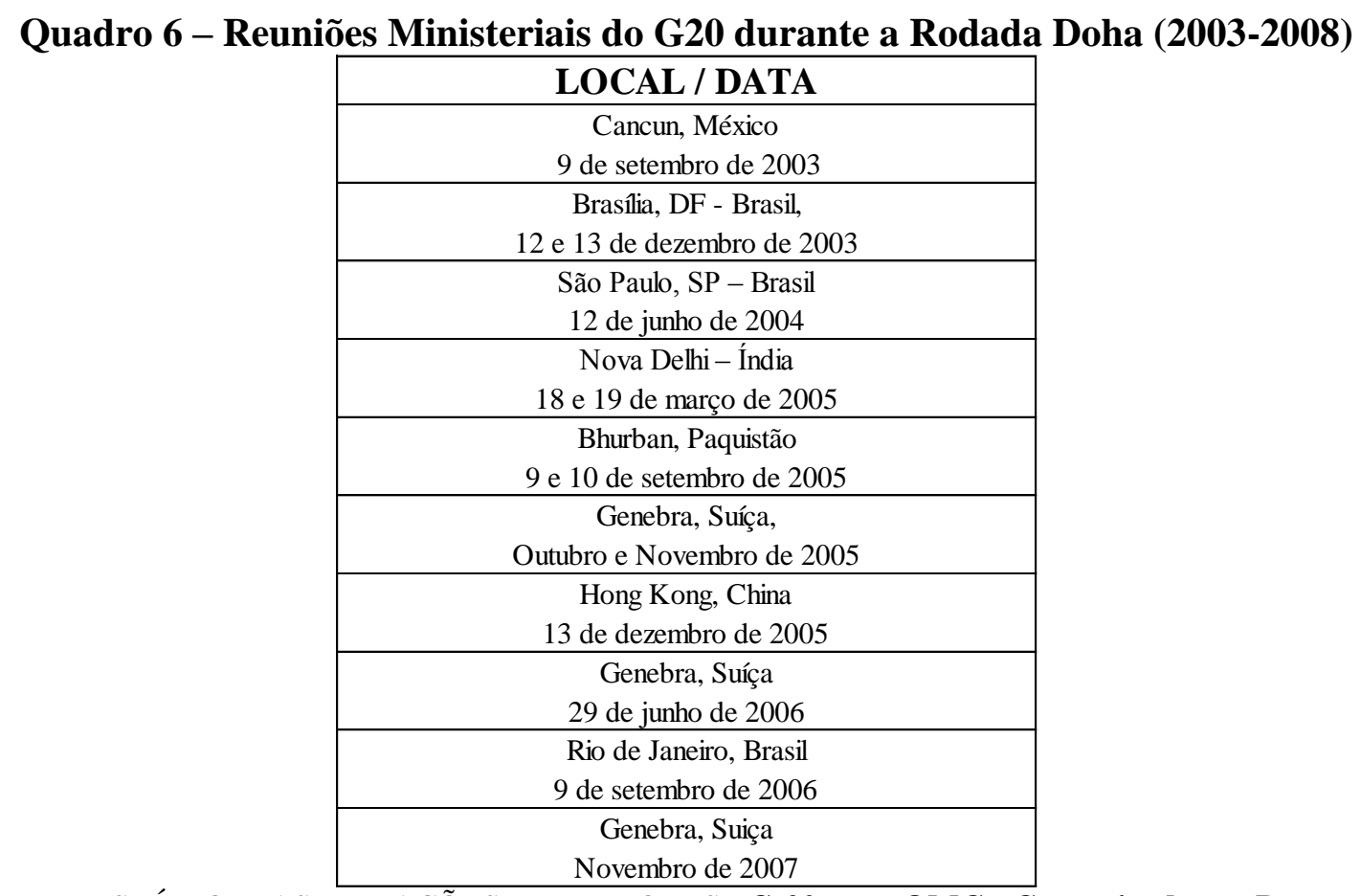

Fonte: MINISTÉRIO DAS RELAÇÕES EXTERIORES. G-20 e a OMC: Comunicados e Documentos. Brasília, DF. Fundação Alexandre de Gusmão, 2007 e MISSÃO DO BRASIL EM GENEBRA, Carta de Genebra. Ministério das Relações Exteriores. 
Gradualmente, o G20 assumiu um papel de protagonista nas negociações, e dois integrantes do grupo (Brasil e Índia) passaram a participar ativamente dos chamados grupos de tomada de decisão (Five Interested Parties - FIPS, G7, G8), formados por países com elevado peso político e que efetivamente são responsáveis pelo debate e norteamento das negociações em sentido amplo.

Entre 2004 e 2005, o trabalho do grupo foi intenso. Com a decisão dos EUA e da UE de efetivamente negociarem no plano multilateral, a complexidade normativa e o debate era crescente, o que exigia das coalizões (especialmente do G20) posicionamentos substanciais e com elementos concretos. Por contar com 12 membros do Grupo de CAIRNS e 13 do G33, as proposições do G20 sempre eram muito bem formuladas, no intuito de conter elementos de interesse tanto do pleito ofensivo (diminuição dos subsídios domésticos, maior abertura comercial) como do defensivo (salvaguarda especial para PEDs, tratamento diferenciado a alguns produtos especiais).

Nas negociações às vésperas do fechamento do Acordo-Quadro de Julho de 2004, além das consultas amplas, o locus negociador principal da Rodada Doha era um grupo de tomada de decisão FIPS, composto por Austrália, Brasil, EUA, Índia e UE. O FIPS representou uma profunda alteração na dinâmica de negociação da OMC, uma vez que passou a substituir o chamado QUAD (Canadá, EUA, Japão e UE) como principal fórum de tomada de decisão das Rodadas. Após quatro meses de intensas negociações no âmbito do FIPS, o Acordo Quadro de Julho de 2004 foi fechado e refletiu importantes ganhos normativos para o G20 ${ }^{139}$.

No pilar de apoio doméstico, a redução dar-se-ia, como sugerido pelo G20, de maneira ampliada e obedecendo ao princípio de tratamento especial e diferenciado, e no cálculo seriam incluídas três importantes formas de subsídio (caixa amarela, de minimis e caixa azul). A previsão que incluía a revisão e clarificação da caixa verde também foi uma importante conquista para o Grupo. Ademais, deve-se destacar, em acesso a mercados, a consolidação normativa da fórmula de redução tarifária em bandas proposta pelo G20 (tiered approach), que previa cortes maiores para as maiores tarifas. Foram previstos também o estabelecimento de um mecanismo de salvaguardas especiais para PEDs e a designação de produtos especiais

\footnotetext{
139 DÂMICO, Flavio S. O G-20 e as negociações agrícolas da OMC. Pontes, Vol. 3, n³, 2007. Disponível em http://ictsd.org/i/news/12473/ Acesso em 20/06/2012, p. 4.
} 
que sofreriam cortes menores. Por fim, deve-se destacar a previsão do fim dos subsídios à exportação em data ainda a ser definida ${ }^{140}$.

Em 2005, visando à consolidação textual no âmbito da VI Conferência Ministerial da OMC, que seria realizada em Cancun, o G20 realizou três Reuniões Ministeriais e elaborou uma série de propostas correspondentes aos três pilares de negociação. Em geral, o grupo deveria concentrar seus esforços para o alcance de dois objetivos: a manutenção dos avanços conquistados no Acordo Quadro de 2004 e o aprofundamento, em termos normativos, dos interesses intracoalizão.

Tendo em vista a Declaração Final da Conferência, o primeiro objetivo foi alcançado. O Sistema de bandas tanto para os cortes sortes nos subsídios domésticos quanto para os cortes tarifários foram reafirmados, apesar de não se ter conseguido avançar em uma fórmula de redução tarifária. Os mecanismos de salvaguarda especial para PEDs e de tratamento diferenciado a produtos especiais foram refinados para o contentamento do G33. No pilar de competição exportadora, foi acordada uma data final para a redução dos subsídios à exportação: $2013^{141}$.

Importante salientar que os resultados da Conferência Ministerial desagradaram parcela significativa dos representantes do agronegócio brasileiro, sobretudo por conta do pouco avanço em acesso a mercados e da criação de mecanismos de salvaguarda especial para PEDs, os quais já representavam mais da metade da exportação agrícola do Brasil à época. Todavia, deve-se destacar que o apoio dado pelo G20 às questões defendidas pelo G33, que tinha na Índia seu principal interlocutor, foi fundamental para a manutenção da coalizão, que atuava sobre pressão externa dos PDs, mantenedores da posição de que, devido às diferenças de posição em acesso a mercados, o G20 viria a rachar ${ }^{142}$.

De qualquer forma, o Brasil, em pronunciamento em nome do G20, na Sessão Especial de Agricultura em janeiro de 2006, reconheceu as limitações do texto acordado em Hong Kong e apontou para a necessidade de avanço textual em outras áreas:

\footnotetext{
${ }^{140}$ MISSÃO DO BRASIL EM GENEBRA, Carta de Genebra. Ministério das Relações Exteriores. Ano 3, No. 3, Junho de 2004. AREIAS, Ana Carolina. Op. cit p. 119-121. WORLD TRADE ORGANIZATION (WTO). Doha Work Programme. 02/08/2004. WT/L/579.

${ }^{141}$ WORLD TRADE ORGANIZATION (WTO). Declaração Ministerial. Conferência Ministerial, 6 a Sessão, 22/12/2005. WT/MIN(05)/DEC e CARVALHO, Maria Izabel Valladão de. Condicionantes Internacionais e Domésticos: O Brasil e o -20 nas Negociações Agrícolas da Rodada Doha. Revista de Ciencias Sociais, Rio de Janeiro, Vol. 53, n², 2010, p.425-429.

${ }^{142}$ DÂMICO, Flavio S. O G-20 e as negociações agrícolas da OMC. Pontes, Vol. 3, n³ 3, 2007. Disponível em http://ictsd.org/i/news/12473/ Acesso em 20/06/2012, p. 4.
} 
The G-20 is pleased that the Membership has been able to avoid a failure in Hong Kong and has kept the Round alive albeit with modest results in agriculture. We left Hong Kong with a sense of relief. The results were limited, but positive, in line with the low expectations we all had for the Conference. The major political issues remain to be solved this year and depend on further movement in domestic support and market access by the major players who are primarily responsible for the distortions in agriculture. We expect they will show leadership and engage seriously in the negotiations ahead. Agriculture remains at the center of the negotiations and represents the engine of this Round.

De meados de 2006 até os primeiro meses de 2007, a Rodada foi paralisada devido aos diversos impasses normativos ocasionados entre PEDs e PDs no âmbito da Reunião Ministerial do G6 (Austrália, Brasil, EUA, Índia, Japão e UE) ocorrida em julho daquele ano. Com a retomada gradual dos trabalhos em 2007, as discussões estavam voltadas para o avanço gradual no texto agrícola, nos três pilares da negociação, e nas negociações em acesso a mercados para bens não agrícolas (NAMA).

Deve-se salientar, contudo, que o ambiente interno de alguns países e blocos desfavorecia o avanço regulatório. Nos EUA, o Trade Promotion Authority (TPA) ${ }^{143}$ havia expirado em 2007 e uma nova Lei Agrícola, mantendo programas distorcivos de apoio doméstico, foi aprovada. Na UE, o viés protecionista crescia, sobretudo após a ascensão de Nicolas Sarkozy ao poder em julho de 2008. O empresariado brasileiro ligado ao agronegócio também passou a criticar com mais veemência as propostas em que o país endossava a criação de um mecanismo de salvaguardas especiais para PEDs e da consolidação de produtos especiais tanto para PDs quanto para PEDs ${ }^{144}$.

O G20, todavia, adotou a mesma postura proativa de 2005 , realizando reuniões ministeriais e elaborando seis propostas ao final de 2007. Entre 21 e 26 de julho de 2008, foi realizada uma reunião mini-ministerial, que contaria com participação de Austrália, Brasil, EUA, Índia, Japão e de outros grupos menores, no intuito de tentar avançar na regulação de bens agrícolas e em NAMA. O encontro foi marcado principalmente pela pressão de EUA e UE por maior abertura dos mercados agrícolas e industrias dos PEDs (negociações horizontais), sobretudo aqueles com economias mais pujantes, como era o caso de Brasil,

\footnotetext{
${ }^{143}$ O TPA é um mecanismo de política comercial norte-americana no qual o Congresso concede ao Presidente da República a garantia deste realizar acordos comerciais e contar com que sua ratificação interna ganhe contornos mais expeditos em termos de procedimentos legislativos. Em: Hornbeck, J. F., COOPER, William H. Trade Promotion Authority (TPA) and the Role of Congress in Trade Policy. Congressional Research Service, 7/04/2011. Disponível em http://www.fas.org/sgp/crs/misc/RL33743.pdf Acesso em 24/06/2012.

${ }^{144}$ CARVALHO, Maria Izabel Valladão de. Condicionantes Internacionais e Domésticos: O Brasil e o -20 nas Negociações Agrícolas da Rodada Doha. Revista de Ciencias Sociais, Rio de Janeiro, Vol. 53, n² 2, 2010, p.429.
} 
India e China. Coube ao G20 sustentar sua posição e pressionar para que as propostas elaboradas pelo grupo fossem incluídas no texto negociador.

Em 25 de julho de 2008, o Diretor Geral da OMC Pascal Lamy, baseado nos inúmeros textos produzidos até então pelos presidentes do Comitê de Agricultura e NAMA, consolidou um texto que ficou conhecido como "Pacote Lamy"145. A despeito das críticas ${ }^{146}$, o texto foi aceito pelo Brasil, EUA e UE, porém não contou com o apoio da Índia (sobretudo no que se refere aos critérios de utilização do mecanismo de salvaguardas especiais para PEDs) e de outros representantes do mundo em desenvolvimento.

De maneira geral, a proposta agrícola atendia aos interesses negociadores do Brasil, e refletia importantes insights oferecidos pelo G20 nos três pilares de negociação, sobretudo no que se refere às fórmulas de redução tarifária (tiered approach) e em subsídios à exportação. No pilar de apoio doméstico, diversas preocupações em relação aos critérios da caixa verde e ao tratamento especial e diferenciado foram, de certa forma, atendidos ${ }^{147}$.

A despeito do impasse ocorrido em 2008, a perspectiva de atuação dos PEDs por meio de coalizões, sobretudo a do G20, deve ser entendida como um ganho substancial em vista dos procedimento decisório e negociador no SMC, sobretudo no que tange à regulação da agricultura em nível multilateral.

Evidentemente, a alteração do tradicional modus operandi de negociação em uma organização que em cinquenta anos tem, em agricultura, basicamente privilegiado uma espécie de tratamento especial e diferenciado às avessas não poderia ocorrer placidamente. O G-20 foi objeto de ásperas críticas e fortes pressões das principais potências, mas a legitimidade de suas posições e a firme condução do Brasil permitiram sua consolidação [...] deu provas de grande consistência técnica em suas propostas, coerência política em seu discurso e atuação e, acima de tudo, de profundo compromisso com o Mandato de Doha e com o objetivo de desenvolvimento a que deve fazer jus esta Rodada ${ }^{148}$.

\footnotetext{
${ }^{145}$ WORLD TRADE ORGANIZATION (WTO). Sessão Especial do Comitê de Agricultura. Revised Draft Modalities for Agriculture. 06/12/2008. TN/AG/W/4/Rev.4

${ }^{146}$ ISMAIL, Faizel. Reflection on the WTO July 2008 Colapse: Lessons for the Developing Country Coalitions. EmNARLIKAR, Amrita; VICKERS, Brendan (eds.). Leadership and Change in the Multilateral Trading System. Republic of Letters Publishing, 2009, p. 203-230.

${ }^{147}$ CARVALHO, Maria Izabel Valladão de. Condicionantes Internacionais e Domésticos: O Brasil e o -20 nas Negociações Agrícolas da Rodada Doha. Revista de Ciencias Sociais, Rio de Janeiro, Vol. 53, n²2, 2010, p.434 e CEDRO, Rafael Rosa. Desenvolvimento Rural e a OMC: a experiência do Brasil. Curitiba: Juruá, 2011, p. $155-184$

${ }^{148}$ MISSÃO DO BRASIL EM GENEBRA, Carta de Genebra. Ministério das Relações Exteriores. Ano 4, n. ${ }^{\circ}$ 6 , setembro de 2005 , p. 6
} 
Como se pode perceber ao longo dos anos que marcaram efetivamente as negociações da Rodada Doha, a formação de coalizões de PEDs na OMC passou a derivar de uma estrutura institucional que permite, e de certa forma, incentiva países de pequeno porte a atuarem de forma conjunta no intuito de enfrentar a assimetria presente na elaboração do conjunto de normas que define o corpo de negociações.

Essas coalizões, principalmente o G20, passaram, gradualmente, a ser protagonistas de embates políticos e comerciais em um sistema complexamente interligado por uma densa rede de interesses múltiplos. O crescente fluxo comercial entre PEDs; a incapacidade, ao longo do tempo, de emergirem como efetivos Agenda Setters nas negociações intrainstituição; a busca por maior peso externo e ampliação da capacidade de barganha; o aumento da credibilidade das propostas, o incremento de pesquisas e a busca por maior legitimidade nas decisões são alguns dos propulsores para essa atuação conjunta ${ }^{149}$.

O primeiro grande destaque do G20 fica por conta da representatividade dos seus membros na produção e no comércio agrícola mundial $(60 \%$ da população mundial, $70 \%$ da população rural em todo o mundo e $26 \%$ das exportações agrícolas mundiais) ${ }^{150}$. Aliado a isso, a notória coordenação dos seus membros e a capacidade de interlocução deste grupo com outras coalizões complementou o alicerce político de atuação do grupo durante as negociações.

O fato de possuir em seu núcleo de formação países que tenham interesses divergentes quanto ao tema de liberalização dos mercados agrícolas, como é o caso do Brasil e Índia, que aceitaram cooperar com eficiência no tripé negociador agrícola do Mandato de Doha fazem com que, a despeito dos custos de ação coletiva intrinsicamente envolvidos na formação de uma coalizão desse tipo, objetivos mais amplos de reforma do Regime sejam perseguidos ${ }^{151}$.

Em que pese o "fracasso" das negociações em 2008, o grupo efetivamente alterou a dinâmica negociadora e conseguiu, como já observado anteriormente, inserir propostas de seu interesse ao longo da Rodada. Essa convergência (mesmo que limitada em alguns temas) de interesses de seus Estados-membros possibilitou a criação de uma agenda demandante consistente e que, gradualmente, ganhou força. Essa constatação permite afirmar que o grupo,

\footnotetext{
${ }^{149}$ NARLIKAR, Amrita. International trade and developing countries: Bargaining coalitions in the GATT \&WTO. London: Routledge 2003.

${ }^{150}$ Fonte: Sítio Oficial do G20. Disponível em <http://www.g-20.mre.gov.br/history_port.asp > Acesso em 21/03/07.

${ }^{151}$ JÚNIOR, Haroldo Ramanzini. O G-20 e a Política Externa Brasileira. Revista Fronteira, setembro 2007. Belo Horizonte: PUC/Minas.
} 
ao longo da Rodada, passou a se comportar como um Agenda Setter ao invés de um Rules Taker dentro da $\mathrm{OMC}^{152}$.

Com isso, potenciais problemas internos em coalizões de PEDs detectados por Odell e Narlikar ${ }^{153}$, como o peso externo mínimo (em virtude das posições de pouco destaque que os PEDs ocupam no Comércio Mundial), e o risco de fragmentação (que tem como fontes a densidade estrutural, a flexibilidade dos interesses estatais e a coesão nas estratégias a serem adotadas) não encontraram respaldo na maior parte da atuação do Grupo.

Faced with a crunch, institutionally and substantively, several powerful coalitions of developing countries galvanised in the run up to Cancun. These coalitions played a key role of resistance at the ministerial. The one that received the most publicity at the time was de the G-22 (originally the G20), led by Brazil, China and India, but with several others also in operation that proved to be just as important in the endgame.[...] Key to the emergence of the group was the disillusionment of many developing countries with the EU-US text on agriculture and a memory of similar collusion in the past by developed countries. It was this same disillusionment that allowed them to arrive at compromises among themselves and thereby to build a sustainable common platform. Examples of this compromise are the support of the G-22 (including its Cairns Group members) for Special and Differential Treatment and the non-trade concerns of the least developed Countries (LDCs) ${ }^{154}$

Apesar de diversos fatores da formação e atuação do G20 encontrarem respaldo nas teorias desenvolvidas por uma gama de autores presentes no capítulo 1 desse estudo, a hipótese de sociabilização e aprendizado exposta por Narlikar parece ser a mais apropriada para explicar as ações do grupo. Segundo a autora ${ }^{155,}$ a chave para a efetiva atuação do G20 está no aprendizado que eminentes países obtiveram com o fracasso de outras coalizões de PEDs na OMC, que eram estruturadas em torno dos ideais de Bloco, mais abrangentes, ou de estratégias do tipo Aliança, do tipo issued-based. Em vez de atuar sob a égide de um só tipo de estratégia, o G20 agregou fatores de ambas e assim, criou uma nova dinâmica estrutural, denominada Sociabilização.

\footnotetext{
${ }^{152}$ NARLIKAR, Amrita. International trade and developing countries: Bargaining coalitions in the GATT \&WTO. London: Routledge 2003.

${ }^{153}$ NARLIKAR, A. and ODELL, J. (2003), The Strict Distributive Strategy for a Bargaining Coalition: The Like Minded Group in the World Trade Organization, 1998-2001', Paper Presented at a Research Conference, Developing Countries and the Trade Negotiation Process (6-7 November,UNCTAD, Palais des Nations, Geneva).

${ }^{154}$ NARLIKAR, Amrita; WILKINSON, Rorden. Collapse at the WTO: A Cancun Post-Mortem. Third World Quarterly. Vol 25, n 3, 2004, p 456.

${ }^{155}$ NARLIKAR, Amrita; TUSSIE, Diana. "The G-20 at the Cancum Ministerial: Developing Countries and their evolving coalitions in the WTO". The World Economy, Oxford, vol. 27, nº. 7, julho de 2004, p. 947-966.
} 
Tal dinâmica é sustentada por uma estratégia distributiva e de resistência focada no tema agricultura (issued-based), porém suas propostas são fruto de extensas deliberações, pesquisas e análises, que agem no intuito de flexibilizar a agenda, conseguindo o máximo de coesão interna e potencializando a legitimidade externa da coalizão (bloc-based):

The G20 has set an important precedent. The coalition has demonstrated that unlike coalitions of the past that succumbed far more easily to divisive tactics in the endgame, at least some coalitions today have devised methods of maintaining internal coherence and also external weight to be able to hold out even in the face of some tempting side-deals. ${ }^{156}$

Como já explicitado, com o estabelecimento de uma nova Rodada de Negociações em 2001, o risco dos diversos mecanismos de pressão dos PDs sobre os PEDs se fazia presente. Novamente, o processo informal de deliberação, a falta de transparência, os side payments e as disparidades quantitativa e qualitativa entre delegações ${ }^{157}$, entre outros meios de influência, poderiam ser usados para a consolidação de acordos assimétricos entre o mundo desenvolvido e em desenvolvimento. No entanto, o colapso de Cancún refletiu as falhas de desenho institucional da OMC e os desequilíbrios na substância temática em seus acordos, sobretudo no AA, o que gerou o ativismo dos PEDs em estabelecer importantes coalizões em face uma dinâmica que poderia se repetir com a proposta conjunta EUA-UE.

O processo de aprendizado, que gera uma adaptação cognitiva e institucional dos PEDs no processo negociador da OMC, sobretudo na V Reunião Ministerial da OMC, em Cancun, estaria relacionado, segundo Narlikar e Hurrell, com quatro fatores: o ativismo institucional dos PEDs em um período anterior à Cancun; a criação de coalizões; as estratégias de negociação e, por fim, a relação das coalizões com organizações não governamentais $(\mathrm{ONGs})^{158}$.

No que se refere ao ativismo institucional dos PEDs em um período anterior a Cancun, os autores destacam a capacidade que essas nações adquiriram em termos de coordenação e compartilhamento de informações em negociações específicas, como é o caso, entre outros, da atuação conjunta do Brasil, Índia e África do Sul nas negociações sobre a interpretação da declaração de TRIPS e Saúde Pública acordada em 2001.

\footnotetext{
${ }^{156}$ NARLIKAR, Amrita; TUSSIE, Diana. "The G-20 at the Cancum Ministerial: Developing Countries and their evolving coalitions in the WTO". The World Economy, Oxford, vol. 27, nº 7, julho de 2004, p. 963.

${ }^{157}$ NARLIKAR, Amrita. International trade and developing countries: Bargaining coalitions in the GATT \&WTO. London: Routledge 2003.

${ }^{158}$ NARLIKAR, Amrita; HURRELL, Andrew. A New politics of confrontation? Developing countries at Cancun and beyond. Global Society, v. 20, n 4, 2006, p.6
} 
Em relação à formação de coalizões, destaca-se o fato de diversos grupos terem origem à época da Rodada Uruguai (como o Grupo de CAIRNS) e, desde então, procurarem atuar de diversas formas na manutenção do seu interesse ${ }^{159}$.

No que se refere à estratégia de negociação, o aprendizado deriva sobretudo do fato de, ao longo do tempo, o negociador perceber qual o melhor movimento (integrativo ou distributivo) em face de um determinado cenário. Por fim, o relacionamento com as ONGs, seja de PEDs ou de PDs, abriu caminho para que os pleitos e demandas das delegações pudessem ter representatividade junto à sociedade civil. Somado a isso, deve-se ter em consideração o ambiente interno dos países e os grupos de pressão (governamentais ou não) interessados na negociação ${ }^{160}$, o que gera uma dinâmica interativa crescente sobretudo em termos técnicos, como foi o caso da participação do Brasil no G20 ${ }^{161}$.

[...]the recent confrontational politics at the WTO need to be understood in terms of cognitive and institutional adaptation by developing countries within a specific institutional context. The "Alliances of Sympathy" that we saw at Cancun were not an atavistic call for a New International Economic Order, nor were they prompted by domestic politics. Rather, they were prompted by decades of interaction and adaptation by the participants within the particular institution. This process is specific to the experience of developing countries within the WTO and seems to maintain a momentum of its own ${ }^{162}$.

A hipótese de aprendizado e sociabilização, no caso do G20, faria parte do amplo objetivo da lógica de formação de uma coalizão, que, segundo Narlikar, é o de prover ganhos coletivos aos seus membros (collective gains hypothesis) em vez de gerar possibilidade de side payments (deffection hypothesis). Isso porque o Grupo, ao estabelecer uma agenda de propostas efetiva (que combinava esforços com outras coalizões de PEDs) e uma relação de confiança entre seus membros, conseguiu auxiliar na alteração do paradigma negociador que

\footnotetext{
159 NARLIKAR, Amrita; WOODS, Ngaire. International Trade and the Emergence of New Inter-State Coalitions. Latin-American Trade Network, Working Papers, 1999. Disponível em http://www.globaleconomicgovernance.org/wpcontent/uploads/International\%20Trade\%20and\%20the\%20Emer gence.pdf. Acesso em 20/06/2012.

160 NARLIKAR, Amrita; HURRELL, Andrew. A New politics of confrontation? Developing countries at Cancun and beyond. Global Society, v. 20, n 4, 2006, p. 7-13.

${ }^{161}$ RAMANZINI JÚNIOR, Haroldo; LIMA, Thiago. Diplomacia Comercial Agrícola: As posições do Brasil na Rodada Doha da OMC. Em AYERBE, Luis Fernando; BOJIKIAN, Neusa (Orgs.), Negociações Econômicas Internacionais: Abordagens, atores e perspectivas desde o Brasil. São Paulo: Editora UNESP: Programa San Tiago Dantas de Pós Graduação, 2011, p. 208.

162 NARLIKAR, Amrita; HURRELL, Andrew. 2006, op. cit., p. 31.
} 
operava desde as Rodadas do GATT marcado por consultas e entendimentos limitados a um pequeno grupo de países desenvolvidos ${ }^{163}$. Segundo Narlikar:

The central explanation behind the survival and power of the G20 lies in its ability to get all its members to commit to the collective agenda on agriculture. The recognition by the G20 members that potential collective gains will outweigh individual payoffs is explicit [...] On being asked about the likelihood of his country from defecting the G20 at Cancún in 2003, a negotiator from a small country stated that the collective gains that could be had if the G20 were successful significantly outweighed any gains that the US or EU could offer him through preferential marked access ${ }^{164}$.

Como se pode perceber, a atuação do G20 ao longo dos anos mais latentes da Rodada Doha (2003 a 2008) foi intensa. De maneira geral, as propostas técnicas conferiam legitimidade aos pleitos de reforma do AA, o que era complementado pela articulação política com outras coalizões dos PEDs. A estratégia cooperativa intracoalizão, com vistas à implementação de uma plataforma conjunta de interesses, buscou acomodar uma gama de demandas que, à primeira vista, pareciam conflitantes. A maior regulação da área agrícola no SMC, o aumento da inclusão e da transparência no processo negociador e o respeito ao princípio do tratamento especial e diferenciado era, todavia, de interesse de todos os PEDs não obstante suas diferenças pontuais.

Com uma postura de enfrentamento direto ao conluio de EUA e UE no processo negociador, o G20 foi criado; e com uma postura extremamente pragmática nas negociações, baseada no respeito ao Mandato negociador de Doha, o G20 manteve-se ativo ao longo da Rodada e tornou-se um elemento central na alteração da dinâmica negociadora e na tentativa de diminuição das práticas distorcivas ao comércio internacional.

\subsection{Os principais aspectos e efeitos da liderança do Brasil no G20}

Conforme exposto no início do texto, a hipótese central do presente trabalho é a de que o Brasil exerceu a liderança do G20 ao longo da formação e atuação do grupo durante a Rodada Doha da OMC entre os anos de 2003 a 2008.

\footnotetext{
${ }^{163}$ Pronunciamento do então Ministro das Relações Exteriores do Brasil, Celso Amorim, em: MINISTÉRIO DAS RELAÇÕES EXTERIORES. G-20 e a OMC: Comunicados e Documentos. Brasília, DF. Fundação Alexandre de Gusmão, 2007, p. 14.

${ }^{164}$ NARLIKAR, Amrita, A Theory of Bargaining Coalitions in the WTO. Em NARLIKAR, Amrita; VICKERS, Brendan (eds.). Leadership and Change in the Multilateral Trading System. Republic of Letters Publishing, 2009, p. 192.
} 
Dessa forma, o presente subitem visa a explorar os aspectos determinantes que consolidaram o Brasil como um líder inconteste da coalizão. A presente análise terá como fundamento quatro entrevistas realizadas com membros da Delegação Permanente do Brasil junto à OMC entre 2003 e 2008, anos em que as negociações efetivamente se desenvolveram e que delimitam este trabalho.

A análise foi baseada em um roteiro de entrevista ${ }^{165}$ que procurou abordar aspectos da atuação do Brasil, durante a formação e atuação do Grupo, e identificar as principais ações que indicam a liderança do Brasil no âmbito da coalizão. Esse modelo de análise, amplamente utilizado por diversos pesquisadores de negociações internacionais ${ }^{166}$, justifica-se pela capacidade qualitativa de coleta de dados derivada de percepções de negociadores e observadores privilegiados, que efetivamente viveram o processo de formação e atuação do G20.

Para tanto, partimos do pressuposto de que a liderança deverá ser entendida como um relacionamento assimétrico em termos de influência, em que um player, dotado de legitimidade, direciona o comportamento coletivo em torno de um determinado objetivo, utilizando um dado meio ao longo de um período. Essa conceituação de liderança deriva das exposições vistas no capítulo 1, sobretudo das explicações de Arild Underdal ${ }^{167}$, Léon Dión $^{168}$, e Oliveira e Onuki ${ }^{169}$.

\footnotetext{
${ }^{165}$ Ver Anexo 1

${ }^{166}$ NARLIKAR, Amrita; TUSSIE, Diana. "The G-20 at the Cancum Ministerial: Developing Countries and their evolving coalitions in the WTO". The World Economy, Oxford, vol. 27, n'. 7, julho de 2004, p. 947-966; NARLIKAR, Amrita; HURRELL, Andrew; A New politics of confrontation? Developing countries at Cancun and beyond. Global Society, v. 20, $\mathrm{n}^{\circ}$ 4, 2006; NARLIKAR, Amrita; WILKINSON, Rorden. Collapse at the WTO: A Cancun Post-Mortem. Third World Quarterly. Vol 25, n 3, 2004, p 447-460 ; STEINBERG, Richard H. "In the Shadow of Law or Power? Consensus-Based Bargaining and Outcomes in the GATT/WTO". International Organization, vol.56, no. 2, Spring 2002. Dezembro 2006, pp. 465-503; GIORDANO DELGADO, Nelson; CAMPOLINA DE O. SOARES, Adriano. G20: Origem, Evolução, Significado e Perspectivas. Latin American Trade Network. Working Paper. Buenos Aires, Facultad Latinoamericana de Ciencias Sociales (FLACSO). no 89, fev. 2008. Disponivel em http://www.latn.org.ar/wpcontent/uploads/2012/03/wp-89-Delgado-Soares-Portugues.pdf Acesso em 02/07/2012; CARVALHO, Maria Izabel Valladão de. Condicionantes Internacionais e Domésticos: O Brasil e o -20 nas Negociações Agrícolas da Rodada Doha. Revista de Ciencias Sociais, Rio de Janeiro, Vol. 53, n², 2010, p.405-445.

${ }^{167}$ UNDERDAL, Arild (1994). "Leadership Theory: Rediscovering the arts of management", In: WILLIAN ZARTMAN (org.): International Multilateral Negotiation, cap. 8, p. 178-197.

${ }^{168}$ DION, Léon. The Concept of Political Leadership: An Analysis. Canadian Journal of Political Science, Vol.1, n¹, Mar. 1968, p. 2-17.

169 OLIVEIRA, Amâncio; Onuki Janina. Negociações Internacionais: Teoria e Técnicas. Em AYERBE, Luis Fernando; BOJIKIAN, Neusa (Orgs.), Negociações Econômicas Internacionais: Abordagens, atores e perspectivas desde o Brasil. São Paulo: Editora UNESP: Programa San Tiago Dantas de Pós Graduação, 2011.
} 
Como destacado anteriormente por Oliveira e Onuki, a liderança (variável dependente) aqui definida deverá derivar de quatro fatores (variáveis independentes) fundamentais: a legitimidade, o sentido de direção, a definição de uma ou mais metas e a utilização de uma ou mais estratégias de atuação. A identificação e o isolamento das variáveis acima visam a aperfeiçoar a relação causal que será utilizada para a mensuração da liderança ${ }^{170}$, destacada anteriormente como um dos desafios da pesquisa desse fenômeno em geral. Abaixo, as definições dos parâmetros que consubstanciam as variáveis independentes.

a) Legitimidade: a variável legitimidade utilizada na presente hipótese de liderança do Brasil no âmbito do G20 deve se relacionar com o conceito de group process, estabelecido por Léon Dion, e explorado no primeiro capítulo. Dessa forma ela deve ser resultado das interações entre os membros da coalizão e conferir um padrão de atuação do líder no âmbito da coalizão, o qual é estabelecido por meio de uma relação funcional entre o(s) líder(es) e os liderados ${ }^{171}$. Além disso, deve possuir elementos de uma liderança comportamental, democrática, empresarial, instrumental, baseada em uma relação de causa e efeito, argumentação e traços de confiança; ou traços autoritários, de liderança estrutural ou coercitiva. ${ }^{172} \mathrm{~A}$ capacidade intelectual do líder deverá também ser considerada uma importante fonte de legitimidade ${ }^{173}$.

b) Estratégia: são as ações empregadas pelo líder para consolidar e manter, ao longo do tempo, sua liderança. Está relacionada, por exemplo, com a capacidade de o líder refletir, em suas ações, as aspirações do grupo, proporcionando a esse uma característica conservadora e inovadora ${ }^{174}$. Além disso, ela deve derivar diretamente do nível de legitimidade alcançado pelo líder, bem como do tipo de liderança exercido em face dos interesses presentes na dinâmica negociadora. A

\footnotetext{
${ }^{170}$ EDINGER, Lewis J., The Comparative Analysis of Political Leadership. Comparative Politics, Vol. 7, №2, 1975, p.269.

${ }^{171}$ DION, Léon. The Concept of Political Leadership: An Analysis. Canadian Journal of Political Science, Vol.1, nº1, Mar. 1968, p. 2-17.

172 EDINGER, Lewis. 1975, op. cit., YOUNG, Oran R. Political Leadership and Regime Formation: On the development of Institutions in International Society. International Organization, Vol.45, no3, 1991, p.281308. e UNDERDAL, Arild (1994). "Leadership Theory: Rediscovering the arts of management", In: WILLIAN ZARTMAN (org.): International Multilateral Negotiation, cap. 8, p. 178-197.

${ }^{173}$ YOUNG, Oran R. 1991, op. cit.

${ }^{174}$ DION, Léon. 1968, op. cit.
} 
liderança e, consequentemente, a estratégia assumem diferentes faces com base na tangibilidade das fontes de poder e na coercitividade no uso de tais fontes ${ }^{175}$.

c) Meta: no âmbito de uma coalizão, a meta deve envolver a instauração de um objetivo compartilhado, que deve ser perseguido ao longo do tempo. A despeito dos diversos interesses intracoalizão que gerarão custos de ação coletiva ${ }^{176}$, o líder deve congregar esforços para a manutenção de uma plataforma comum de atuação do grupo.

d) Sentido de Direção: é resultado do empreendedorismo político do líder, que de alguma forma oferece uma alternativa viável de ação conjunta para os liderados ${ }^{177}$. Os fatores intrínsecos ao contexto da negociação (fontes da liderança) ${ }^{178}$ e a capacidade de resposta do líder aos desafios são fatores que interferem diretamente no sentido de direção que o líder propicia aos outros membros. Por fim, pode-se dizer que esse norteamento deriva diretamente da capacidade e do comportamento individual do líder ${ }^{179}$.

\subsubsection{Apresentação dos resultados}

\subsubsection{O Brasil e a formação do G20}

No que concerne à formação do grupo, as entrevistas ratificaram a perspectiva explorada no presente texto de que a criação do G20 não foi algo espontâneo ou natural. Pelo contrário, ela correspondeu a uma necessidade específica de ação dos PEDs, em um dado momento negociador, no qual EUA e UE tentaram realizar um desfecho para a negociação agrícola que lesaria uma quantidade enorme de países. O Brasil, conforme se pode evidenciar,

\footnotetext{
175 OLIVEIRA, Amâncio; Onuki Janina. Negociações Internacionais: Teoria e Técnicas. Em AYERBE, Luis Fernando; BOJIKIAN, Neusa (Orgs.), Negociações Econômicas Internacionais: Abordagens, atores e perspectivas desde o Brasil. São Paulo: Editora UNESP: Programa San Tiago Dantas de Pós Graduação, 2011. ${ }^{176}$ OLSON, Mancur. (1999), A lógica da Ação Coletiva. Os Benefícios Públicos e uma Teoria dos Grupos Sociais. Tradução Fábio Fernandez. São Paulo, EDUSP.

${ }^{177}$ HARDIN, Russel (1982), Collective Action. Baltimore, The John Hopkins University Press.

${ }^{178}$ EDINGER, Lewis J., The Comparative Analysis of Political Leadership. Comparative Politics, Vol. 7, №2, 1975, p.253-269 e YOUNG, Oran R. Political Leadership and Regime Formation: On the development of Institutions in International Society. International Organization, Vol.45, n⿳03, 1991, p.281-308.

179 UNDERDAL, Arild (1994). "Leadership Theory: Rediscovering the arts of management", in WILLIAN ZARTMAN (org.). International Multilateral Negotiation, cap. 8, p. 178-197.
} 
foi o país que, naquele primeiro momento, teve a concepção intelectual da coalizão, a ideia inicial de formação da coalizão.

Havia, segundo uma fonte diplomática, uma percepção política geral de se evitar, durante a negociação da Rodada Doha, o mesmo processo de tomada de decisão que havia conduzido ao pouco ambicioso desfecho da Rodada Uruguai, principalmente no que diz respeito aos interesses brasileiros. Um dos motivos para aquele desfecho foi, segundo um negociador brasileiro, a existência de uma acentuada divisão entre os PEDs, em que o nível de desconfiança mútua entre países exportadores agrícolas e aqueles com elevada agricultura de subsistência foi habilmente explorado pela Europa e pelos EUA.

Para o Brasil, desde o início da Rodada, essa vulnerabilidade entre os PEDs estava muito clara, e qualquer mudança de status quo do processo decisório deveria levar em conta a criação de uma outra lógica de atuação. O Brasil, naquele momento, tinha a percepção de que somente uma estratégia de convergência e compatibilização de interesses entre os países que estavam emergindo economicamente (Brasil, Índia, China e África do Sul) poderia alterar o processo de tomada de decisão no âmbito da Organização. Para o Brasil, somente por meio de um entendimento conjunto entre essas nações, as desconfianças relacionadas aos objetivos e as metas entre os PEDs membros da OMC poderiam ser superadas, e um ponto de convergência poderia ser estabelecido, com o intuito de viabilizar uma atuação mais eficaz do mundo em desenvolvimento no capítulo mais sensível da Rodada, que era o de Agricultura.

A estratégia brasileira de reunir apoio político para sua proposta de atuação conjunta na Rodada começou, então, a ser gradualmente moldada . Conforme evidenciado por um negociador, tanto a China, que apesar do peso econômico ainda era de certa forma desconhecida em termos de atuação dentro da OMC, quanto a África do Sul não apresentavam a projeção necessária para alterar o curso de ação vislumbrado pelo Brasil. Na geometria de correlação de forças do mundo em desenvolvimento na OMC, somente a Índia, naquele momento (2003), poderia ser identificada como um parceiro em potencial para a viabilização do G20.

O Brasil, dessa forma, aproximou-se do país da Ásia meridional, o qual ainda tinha, segundo negociadores brasileiros, uma percepção muito arraigada de que o perfil de atuação do Brasil estaria ligado aos interesses do Grupo de CAIRNS. Ao aproximar-se da Índia, o Brasil fez o projeto de alteração do status quo do processo de tomada de decisão, e expos que a Rodada só poderia ser bem sucedida de acordo com os interesses dos PEDs, se o Brasil e 
Índia, como países paradigmáticos das duas vertentes do mundo em desenvolvimento presente na OMC, pudessem chegar a um acordo comum. Segundo uma fonte diplomática, o Brasil mostrou ênfase, no diálogo com os indianos, na preocupação com a agricultura de subsistência ou familiar, a qual, conforme mostrada anteriormente, é essencial para a economia nacional.

Com base na aproximação e no diálogo entre Brasil e Índia, criou-se uma base de confiança que, gradualmente, originou uma plataforma sólida visando à operação conjunta. Ambos, no entanto, decidiram que seria importante alargar esse núcleo duro da negociação, o que fez com que o convite de adesão ao projeto de atuação na Rodada fosse estendido à Argentina, um país tipicamente exportador de CAIRNS, porém ligado geopoliticamente ao Brasil; à China, economicamente importante; e à África do Sul. Depois da formação desse novo núcleo duro, conseguiu-se chegar a um documento comum do grupo às vésperas da Reunião de Cancun. Segundo fontes diplomáticas, todos os países do grupo solicitaram que o Brasil apresentasse o texto no fórum amplo das negociações.

Em linhas gerais, pode-se evidenciar, a partir das entrevistas, que houve uma elevada perspectiva de objetividade na proposição da coalizão por parte do Brasil, por conta de alguns fatores como, por exemplo, o caráter de aprendizado que as Rodadas anteriores proporcionaram ao Brasil, munindo o país de um nível de análise apurado, que permitiu identificar como ponto essencial do processo de tomada de decisão na OMC, além do conluio recorrente entre os PDs, a falta de um projeto específico de atuação entre os PEDs.

Além disso, a crescente pujança do setor agroexportador brasileiro e a necessidade de manutenção das medidas relacionadas à agricultura domiciliar também eram propulsores para um engajamento mais apurado do país. Por fim, destacam-se os elementos conceituais da Rodada Doha, que carregava consigo o viés desenvolvimentista, a ser viabilizado, de acordo com seu Mandato negociador, por meio da ampliação do acesso a mercados e da diminuição das medidas distorcivas e prejudiciais ao comércio internacional.

Por conta desse contexto, o Brasil pode definir uma meta clara na formação e atuação do G20, a qual era, justamente, o cumprimento do Mandato negociador de Doha na área agrícola, que propugnava, como já exposto, o estabelecimento de um sistema comercial mais 
justo e de um programa de reforma das regras e dos compromisso específicos de suporte, visando a corrigir e equilibrar as distorções existentes nos mercados agrícolas ${ }^{180}$.

Essa busca pela ampla reforma da regulação agrícola em nível multilateral teve, conforme evidenciado pelos negociadores, uma dupla função: além de ter se tornado o elemento aglutinador do grupo em nível interno, também o proveu de legitimidade externa para atuar durante a negociação, já que a Rodada abria espaço para esse tipo de atuação, voltada tanto à ampliação dos fluxos de comércio global como à implementação de regras equilibradas, voltadas às necessidades dos PEDs e PMDRs em termos de desenvolvimento econômico.

Além da particularidade do contexto negociador exposta acima, outros elementos, como as assimetrias de poder institucional; as especificidades técnicas da negociação agrícola; a diversidade dos interesses internos; entre outros, foram, segundo negociadores brasileiros, elementos essenciais (fontes) à consolidação do Brasil como líder dentro do G20.

\subsubsection{A atuação do Brasil após a formação do G20}

Como se pode perceber, a atuação do Brasil foi crucial para, com base nas particularidades do processo negociador à época, angariar os elementos políticos necessários à formação do G20. O país, gradualmente, passou a ocupar um papel central na definição das diretrizes e estratégias de atuação da coalizão, obtendo cada vez mais legitimidade em suas propostas e na sua liderança intrabloco ao longo da Rodada. As três variáveis (legitimidade, estratégias e senso de direção) serão o foco do presente subitem.

Em linhas gerais, a legitimidade da liderança do Brasil no âmbito da coalizão provinha, segundo fontes entrevistadas, de dois elementos: o intelectual e o funcional. Ambos passaram a atuar de maneira coordenada, complementando um ao outro no âmbito da estratégia brasileira de (a) democratizar a informação entre os membros do grupo; (b) trazer ideias novas à negociação; e (c) prestar serviços à coalizão sobretudo por meio da formulação de propostas negociadoras e da clarificação das variáveis em jogo durante a Rodada.

No que se refere à formulação das propostas, elemento central à atuação do Brasil de acordo com os entrevistados, a legitimidade da liderança brasileira decorria principalmente do

\footnotetext{
${ }^{180}$ WORLD TRADE ORGANIZATION (WTO). Declaração Ministerial. Conferência Ministerial, $4^{\text {a }}$ Sessão, 20/11/2001. WT/MIN(01)/DEC/1.
} 
processo de consulta interna aos grupos de interesse nacionais. Segundo fontes diplomáticas, a posição negociadora do Brasil nasceu fundamentalmente dentro do país.

Todos os processos de consulta realizados internamente tiveram o intuito de trazer para o universo negociador os interesses dos representantes da agricultura familiar, do agronegócio, dos diferentes setores do governo, entre outros players. Essa dinâmica permitiu que, quando as propostas chegassem ao G20, não fossem propostas maximalistas, já que continham elementos das diversas realidades que existiam e ainda existem dentro do Brasil na área agrícola. Como diversas propostas à época eram elaboradas pelo Brasil, deliberadas entre os membros e aceitas no âmbito do G20, o grupo naturalmente adotou uma posição de "meio de caminho", procurando ser um veio natural de convergência das diferentes opiniões. Dessa forma, a relação funcional entre o líder e os outros membros foi facilitada pela dinâmica empregada pelo Brasil de apresentar ao grupo propostas flexibilizadas, que, em sua maioria, se tornariam posteriormente propostas do G20.

A posição do G20 era de meio, porque havíamos encontrado uma convergência. Para que você construa o consenso amplo na negociação, você precisa criar o consenso dentro dos Grupos. O grande achado do G20 foi criar um consenso dentro do grupo, o que era uma pré-condição para que houvesse uma posição global. Os EUA, o Grupo de Cairns e a UE não conseguiram encontrar esse consenso, então eles obstruíram a negociação. Eles não encontraram uma fórmula que os atendesse também entre eles. Contudo, como ninguém queria assumir o ônus de romper as negociações, EUA e UE ficavam permanentemente shifting-blames. Já o Brasil tinha encontrado uma base e deixou bem claro qual seria a plataforma de atuação $^{181}$.

Diversos mecanismos internos de articulação (como o Grupo Técnico Informal - GTI, por exemplo) foram elementos fundamentais à capacidade de articulação do Brasil no G20. Tinha-se presente que a perspectiva particular de apenas um player interno (fosse ele do governo ou do setor privado) não apresentava as condições necessárias à formulação de propostas robustas, haja vista suas limitações específicas, fosse em termos de capacidade da leitura política da negociação ou do conhecimento das demandas do setor privado.

Dessa forma, a complementaridade e o debate no âmbito do GTI, visando a otimizar o uso das informações obtidas e elaborar propostas objetivas, compuseram uma estratégia que almejava equilibrar os anseios dos setores público e privado internos; e auxiliar na manutenção da legitimidade da liderança do país dentro do Grupo. A estratégia deu certo, e

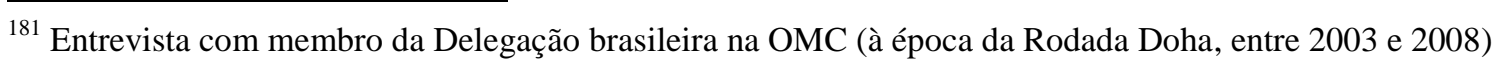


fez com que o país se tornasse o principal responsável pela elaboração de propostas a serem apresentadas nas reuniões do Comitê de Agricultura e do Comitê de Negociações Comerciais.

As coisas evoluíam em uma velocidade extraordinária. A maior parte dos membros do Grupo não tinham as informações. Nós tínhamos. Tínhamos porque "forçávamos a mão". Chegávamos para os europeus e para os americanos e exigíamos determinada informação sob pena de pararmos o processo negociador, e eles nos forneciam as informações. A equipe negociadora do Brasil, com base nessas informações, ponderava, refletia e elaborava as propostas. Os outros não tinham a capacidade técnica para responder, e nós tivemos que desenvolver isso. Se fosse somente o Itamaraty, também não teríamos essa capacidade técnica. Nós tivemos essa capacidade técnica porque o MAPA (Ministério da Agricultura, Pecuária e Abastecimento), o ICONE (Instituto do Estudo do Comércio e Negociações Internacionais) e outros estavam envolvidos. Essa estratégia deu ao Brasil uma capacidade única de formulação de propostas que não se via no restante dos membros do $\mathrm{G} 20^{182}$.

A forte posição externalizada pelo Brasil e pelo Grupo na defesa do Mandato negociador de Doha, ajudou, segundo entrevistados, a ampliar a percepção de que o G20 realmente tinha um ideal central de atuação, fato que, gradativamente, concedeu-lhe influência no direcionamento das discussões em geral. Conforme evidenciado, a atuação do Grupo foi gerando, segundo um negociador brasileiro "uma gradual massa crítica de percepção positiva dos outros países em relação ao G20 e ao Brasil"183.

Entretanto, havia, obviamente, diversos desafios internos que gradualmente eram colocados à atuação brasileira. $\mathrm{O}$ trabalho do país para a manutenção do consenso obtido no início da negociação era constantemente realizado, e as propostas debatidas no âmbito nacional deveriam ser ratificadas pelo grupo. No âmbito dessa relação funcional entre o líder e os outros membros da coalizão, o maior desafio do Brasil foi congregar o interesse coletivo em torno dos três pilares da negociação agrícola (apoio doméstico, acesso a mercados e subsídios a exportação), porém principalmente no que se refere ao tema de acesso a mercados.

Segundo um negociador brasileiro, o tema de subsídios à exportação foi aquele em que o consenso foi alcançado com mais facilidade, sobretudo pelo fato de que praticamente ninguém no grupo tinha políticas amplas de subsídios à exportação (nem mesmo os países mais protecionistas, como a Índia), devido à condição econômica da maior parte dos seus membros. Esse fato facilitou a univocidade do grupo em torno desse pilar de negociação e

\footnotetext{
${ }^{182}$ Entrevista com membro da Delegação brasileira na OMC (à época da Rodada Doha, entre 2003 e 2008).

${ }^{183}$ Idem.
} 
permitiu que o Brasil e o G20 lançassem mão de uma postura demandante na eliminação dos subsídios à exportação no nível multilateral

No que se refere ao pilar de apoio doméstico, o negociador destaca que, apesar da necessidade de trabalho e discussões internas em torno do tema, poucas dificuldades extremas foram detectadas na busca por consenso intragrupo, já que diversos países também não tinham a capacidade de manter programas de subsídios internos no nível daqueles utilizados por EUA e UE. Esse fato facilitou a obtenção de uma estratégia conjunta ofensiva do Grupo nos pedidos de redução do apoio doméstico.

A questão mais delicada, no entanto, estava na contrapartida a ser dada pelos PEDs ao demandar a abertura de mercados dos PDs. China, Índia, Indonésia, Filipinas, entre outros, tinham dificuldades em abrir exacerbadamente seus mercados, de forma que necessitavam proteger certos setores agrícolas importantes para a economia nacional. A saída encontrada pelo Brasil, todavia, foi a de elaborar uma fórmula de redução tarifária que concedesse tratamento especial e diferenciado aos PEDs, indicando que o corte tarifário em maior escala fosse direcionado às maiores tarifas (geralmente relacionadas aos PDs), conceito que deu origem à Fórmula de bandas ou tiered approach.

A expansão mais modesta de acesso a mercados que era possível para países como a China e Índia amarrava o que a gente podia pedir dos outros. Nós atingimos [com a fórmula] um certo equilíbrio, em que conseguíamos abrir o mercado dentro do possível dos países importadores líquidos de alimentos e ainda podíamos pedir um aumento expressivo de acesso a mercados nos países ricos. Dessa modo, "fechamos" o grupo e "fechamos" os três pilares. Apesar das modestas opiniões dos outros membros, toda a estrutura da fórmula foi elaborada pelo Brasil, e na medida em que havia a necessidade de aperfeiçoar tal fórmula, o Brasil também assumia o papel de liderança. As propostas técnicas do G20 foram, em sua imensa maioria, elaboradas pelo Brasil. Havia obviamente algum tipo de ajuste para a acomodação de interesses, porém a estrutura, o conceito, a ideia, era tudo do Brasil"184

O aprendizado adquirido nas Rodadas anteriores, o qual possibilitou ao país alcançar um elevado nível de conhecimento técnico da negociação, bem como o processo de consultas internas auxiliaram o país a ampliar seu capital intelectual e definir melhor sua base de negociação. Como se pode ver, a capacidade de articulação intracoalizão do país com outros membros possibilitou que, gradualmente, os textos negociados contivessem elementos correspondentes às demandas do grupo nos três pilares acima destacados, bem como refletisse em larga escala os interesses do Brasil, sobretudo naquilo que viria a ser a etapa final da

\footnotetext{
${ }^{184}$ Entrevista com membro da Delegação brasileira na OMC (à época da Rodada Doha, entre 2003 e 2008).
} 
negociação, em julho de 2008, quando os interesses brasileiros estavam, segundo um negociador entrevistado, devidamente representados no texto final apresentado pelo Diretor Geral da OMC:

Quando se chegou ao final da negociação [agrícola], tudo que era interessante para o Brasil estava contemplado no pacote. Quem não teve habilidade e viu seus temas ficar de fora [do pacote final] começou a se mobilizar em pontos específicos que deveriam ter sido negociados antes. A coalizão trouxe tudo que o Brasil queria, e a liderança intelectual do país era tão forte que estávamos praticamente ditando o ritmo da negociação [agrícola] intra e extra coalizão. Eles [EUA e UE] sempre souberam que nós íamos negociar duro, nunca duvidaram na nossa vontade de fechar a negociação. Eles tinham dúvidas, no entanto, se nós íamos ser capazes de trazer junto os mais recalcitrantes, como Argentina por um lado e Índia por outro $^{185}$.

Todavia, a definição do sentido de direção a ser tomado pelo Grupo não era uma tarefa fácil. Por ser um grupo grande, o G20 operava em subgrupos, e o core interno de tomada de decisão era composto por Brasil, Índia, China, Argentina e África do Sul. Por deter mais pesquisa e capacidade técnica, o Brasil efetivamente operava para equilibrar os interesses do grupo tanto no âmbito dos subgrupos quanto em relação a outros membros importantes como Uruguai e Tailândia.

Em momentos de questionamentos de sua posição por membros do G20, o Brasil buscava manter suas propostas com firmeza e propriedade, contribuindo para que assumisse definitivamente a liderança do Grupo quanto à definição da direção a ser tomada em temas complexos:

Quando alguém questionava a posição do Brasil por conta de ter realizado, por exemplo, algum tipo de concessão à primeira vista desnecessário, como no debate sobre a ampliação da regulação da Caixa Verde de subsídios, em que poucos tinham uma noção clara daquilo que se tratava tal negociação, nós, que tínhamos um instrumental técnico apurado, que tínhamos batalhado o contencioso do algodão, que tínhamos uma noção mais clara da lei da OMC sobre programas distorcivos e não distorcivos dizíamos aos outros membros do Grupo: "Eu sei, eu estive lá. Isso afeta a mim mais do que a vocês. Então, o ponto que você está dizendo que eu estou fazendo uma concessão exagerada não se sustenta, porque nós sabemos melhor do que ninguém o que nos prejudica". Tem-se aí um exemplo de diálogo que não é autoritário, mas é de autoridade ${ }^{186}$.

Gradualmente, a percepção generalizada entre os membros de que era o Brasil que deveria direcionar tecnicamente o grupo passou a ganhar força. Com isso, não somente as

\footnotetext{
${ }^{185}$ Entrevista com membro da Delegação brasileira na OMC (à época da Rodada Doha, entre 2003 e 2008).

${ }^{186}$ Idem
} 
propostas, como já exposto, mas também a convocação de reuniões, a preparação de papéis para discussão, a realização de pronunciamentos, entre outros procedimentos, eram realizados majoritariamente pelo Brasil, que passou a atuar em nome do Grupo e a auxiliar decisivamente no direcionamento das posições do mesmo.

O G20 era, acima de tudo, um grupo heterogêneo. Então, se conseguíssemos trazer um grupo heterogêneo daquele jeito em um determinado sentido, seria impossível que os outros não se dessem conta de que aquela posição, no fim das contas, deveria ser levada em consideração no âmbito da negociação ${ }^{187}$.

Como líder, o Brasil também teve que elaborar, além das estratégias técnicas, inerentes à negociação, estratégias políticas que visassem exclusivamente à manutenção da estrutura da coalizão. Por exemplo, em relação à saída de membros do grupo, devido a pressões externas (side payments), o Brasil estabeleceu um bottom line para a situação, que era justamente o de trabalhar para que Índia, China, África do Sul e Argentina (membros fundadores da coalizão) se mantivessem no Grupo. Enquanto estes players estivessem no G20, a coalizão ainda teria consistência suficiente para resistir a outras pressões e seguir negociando.

Talvez o melhor exemplo, extraído das entrevistas, de um tipo de ação brasileira que reflita a estratégia política de manutenção do Grupo seja em relação à Índia, ainda nos primórdios da atuação do G20. Conforme exposto por uma fonte diplomática, a Índia, mesmo tendo compactuado com a ideia de criação do G20, tinha interesses, sobretudo em acesso a mercados, obviamente divergentes de outros membros do Grupo, entre eles o Brasil.

Quando o Grupo foi formado em 2003, o objetivo principal do G20 era o de resistir à pressão de se fechar um texto em Cancun que favorecesse os PDs e manter o foco da negociação no Mandato negociador de Doha. Passada a Reunião Ministerial de Cancun, no entanto, fazia-se necessária a consolidação do G20 como um grupo negociador forte e duradouro.

Nesse sentido, o Brasil, lançando mão dos seus traços de liderança, primeiramente propôs de maneira estratégica que uma reunião ministerial do G20 no Brasil fosse realizada após o impasse ocorrido no México. Para a reunião, convidou o Diretor Geral (DG) da OMC, Supachai Panitchpakdi, e outros membros das delegações dos PDs (como por exemplo, o Comissário da UE, Pascal Lamy) no intuito mostrar a coesão e força do Grupo a importantes

\footnotetext{
${ }^{187}$ Entrevista com membro da Delegação brasileira na OMC (à época da Rodada Doha, entre 2003 e 2008).
} 
players da negociação. Segundo uma fonte diplomática, quando o DG da OMC aceitou o convite e veio à reunião em que o Grupo mostrou boa capacidade articulação e diálogo, houve a percepção de que o grupo realmente era uma peça importante das negociações. A UE e os EUA teriam que aceitar aquela nova realidade negociadora, que se consolidou, em 2004, com a alteração da dinâmica de tomada de decisão em pequenos grupos, a qual até então ocorria por meio do QUAD e passou para o FIPs.

Foi exatamente durante esse processo que o Brasil atuou decisivamente para a consolidação da Índia como um importante interlocutor do G20 e dos PEDs, já que defendeu a entrada da Índia no FIPs sob pena de não acatar a formação deste núcleo de tomada de decisão, caso o país da Ásia meridional não estivesse nele incluído. Tratou-se de uma decisão que traria dois benefícios: em primeiro lugar, mitigaria o quadro assimétrico de negociação que poderia se desenhar se as conversas envolvessem somente Austrália, Brasil, EUA e UE. Em segundo plano, ampliou o alcance de atuação do G20, que contaria, a partir de então, com dois representantes na mais importante instância informal de decisão e direcionamento da Rodada.

Em suma, as entrevistas destacaram que, seja em nível técnico ou político, o esforço do Brasil em atuar na manutenção da coesão interna do grupo concederam ao país um papel central na dinâmica negociadora. Conforme exemplificou um negociador brasileiro consultado, em uma negociação internacional em que há de se lidar com algo extremamente complexo que é consenso e na qual há uma presunção de que os atores queiram chegar a um resultado positivo, porém tem interesses divergentes; compete aos líderes da negociação encontrar o mínimo denominador comum , e gradualmente implementá-lo junto aos membros, testando obviamente seus limites junto às sensibilidades de cada um. Segundo o entrevisto em questão, "essa dinâmica foi bem operada pelo Brasil""188.

\footnotetext{
${ }^{188}$ Entrevista com membro da Delegação brasileira na OMC (à época da Rodada Doha, entre 2003 e 2008).
} 


\section{Conclusão}

Como se pode perceber ao longo do texto e, principalmente, por conta dos documentos consultados e entrevistas realizadas, a atuação do G20, bem como a de vários países emergentes, foram de fundamental importância para a evolução, em termos de efetiva inclusão dos PEDs e PMDRs, do processo de tomada de decisão do SMC.

A despeito de todos os critérios que qualificam esse tipo de inclusão, deve-se atentar para o fato de que os padrões de negociação evidenciados desde as Rodadas do GATT até à V Conferência Ministerial da OMC, em Cancún, em 2003, foram marcados tanto pela assimetria entre os membros, a qual era habilmente explorada para a implementação de políticas dos PDs; bem como pela falta de uma efetiva estratégia que pudesse, pelo menos, apresentar uma plataforma conjunta de propostas dos PEDs.

Em face disso, deve-se destacar o papel do Brasil tanto na formulação quanto na manutenção desse processo, que buscava a reforma da dinâmica negociadora e a revisão das normas até então estabelecidas na área agrícola, as quais privilegiavam os países adeptos de medidas com efeitos distorcivos ao comércio internacional.

Conforme se pode evidenciar, o Brasil foi um líder no âmbito do G20, pois reuniu condições essenciais para tanto. As fontes de sua liderança, aglutinadas em uma dinâmica que envolvia as particularidades do Mandato negociador, as assimetrias de poder institucional, as especificidades técnicas da negociação agrícola e a diversidade dos interesses internos, fizeram com que o país adotasse, no âmbito de sua atuação dentro do Grupo, estratégias e metas a serem implementadas no decorrer da negociação. Essas, por sua vez, foram essenciais para que o Brasil elevasse o nível do diálogo interno e provesse o grupo de um senso de direção apurado em momentos cruciais da negociação.

No nível político, a manutenção do núcleo do grupo (Argentina, África do Sul, Brasil, China e Índia), foi detectada como essencial, segundo os negociadores, para que houvesse a possibilidade de a posição dos PEDs, e consequentemente os interesses do Brasil, ganharem voz e peso nas negociações. No nível técnico, a estratégia constantemente defendida pelo Brasil, desde a formação do Grupo, de realizar propostas dotadas de certo nível de flexibilização, que buscava congregar os interesses ofensivos e defensivos dos membros do Grupo, foi um elemento fundamental na coesão interna do Grupo. 
Essa capacidade de refletir as aspirações do G20, já que grande parte das propostas advinha do Brasil, foi responsável pelo sucesso, durante grande parte das negociações, da operacionalização da relação funcional existente entre o país e os outros membros do grupo. Ademais, influenciou diretamente no nível de legitimidade alcançado pelo país tanto no âmbito intracoalizão quanto na negociação mais ampla com os PDs.

O empreendedorismo político fez com que o Brasil assumisse os custos de ação coletiva de deixar a posição maximalista defendida até o início da Rodada de Doha e encampar ações mais amplas em sua plataforma de negociação. A despeito das críticas, sabiase que era necessário encontrar elementos convergentes entre os PEDs, assim como fizeram EUA e UE nas rodadas anteriores, para que um mínimo de atuação efetiva fosse possível.

De acordo com as entrevistas realizadas, foi possível identificar aspectos múltiplos de lideranças distintas que se complementam. O Brasil, ao buscar impingir elementos democráticos e de participação efetiva de outros membros no processo de tomada de decisão da coalizão, passou a reduzir os custos de ação coletiva, buscando congregar os interesses individuais, o que lhe denota um caráter de líder empresarial. No entanto, para que essa dinâmica fosse possível, o país utilizou-se de capital intelectual, demonstrando periodicamente um amplo conhecimento de causa e notória sensibilidade para entender as motivações, os constrangimentos e as pressões a que cada ator estava submetido.

Em resumo, apesar de ter sido um processo extremamente complexo, a capacidade de coordenar o Grupo e de se adaptar a momentos específicos da negociação, sugerindo propostas agregadoras, deu a liderança inconteste ao Brasil. Liderança que utilizava, em suma, fontes de poder intangíveis e políticas de persuasão em seu uso (Liderança Persuasiva Instrumental), combinação que, em última instância, permitiu que o país entrasse definitivamente para o centro decisório da OMC.

Constata-se, portanto, de acordo com a hipótese central do trabalho, que o Brasil foi, pelas diversas razões já destacadas, um líder intracoalizão, buscando essencialmente defender seus interesses, bem como os do grupo, no contexto negociador do Sistema Multilateral de Comércio. Ademais, é necessário indicar que, apesar das limitações da coalizão, sobretudo por conta de interesses divergentes evidenciados principalmente diante do impasse negociador de 2008, a atuação do G20 deve ser vista como um elemento que permitiu, pela primeira vez durante as Rodadas do SMC, a articulação de interesses comuns em um contexto que até então predominava, de maneira geral, a divergência e a desconfiança entre os PEDs. 
Por fim, é necessário salientar que, apesar de a presente pesquisa ter buscado contribuir para o debate sobre a liderança política internacional, sobretudo no âmbito das coalizões multilaterais, há aspectos que necessitam ser explorados. Conforme se observou ao longo do texto, o estudo sobre a liderança ainda deve ser aperfeiçoado, principalmente no que se refere à escolha das variáveis que devem caracterizar o fenômeno. A escolha das variáveis independentes é o núcleo fundamental para a mensuração quantitativa ou qualitativa da liderança, e deve, indubitavelmente, ser o centro da atenção de pesquisas posteriores. 


\section{in \\ INSTITUTO DE RELAÇÕES INTERNACIONAIS - UNIVERSIDADE DE SÃO PAULO \\ Pós Graduação Strictu Sensu em Relações Internacionais (Mestrado) \\ COALIZÕES INTERNACIONAIS E O G-20: ASPECTOS DA LIDERANÇA BRASILEIRA NA RODADA DOHA DE DESENVOLVIMENTO DA OMC}

Aluno: José Luiz Pimenta Jr. Orientadora: Prof ${ }^{a}$. Dra. Janina Onuki

\section{ROTEIRO DE ENTREVISTA}

1) Que fatores você destacaria sobre a atuação do Brasil no G20 tanto na formação quanto na atuação da coalizão ao longo da Rodada Doha?

2) Em relação à liderança brasileira no G20:

I) Caracterize as fontes dessa liderança (assimetrias de poder institucional, particularidades da negociação e do regime, interesses convergentes, etc.).

II) Encontre fatores que caracterizem a liderança brasileira no grupo, tendo como referência as tipologias abaixo (as opções não são excludentes entre si):

a) Liderança autoritária/estrutural: baseada na hierarquia e no poder político-econômico que o país ocupa no sistema internacional.

b) Liderança democrática/comportamental/instrumental: imprime a necessidade de constante argumentação do líder em relação aos outros membros do grupo, sobretudo em relação à defesa do interesse coletivo. Há um ideal de legitimidade do líder em relação aos membros do grupo.

c) Liderança empresarial: capacidade de congregar os interesses individuais, elencar temas prioritários para o grupo e reduzir os problemas de ação coletiva, com o objetivo de alcançar consenso intracoalizão.

d) Liderança intelectual: capacidade de gerar capital intelectual para a negociação (novas propostas que são, geralmente, aceitas pelo grupo e refletidas no processo negociador).

3) Em sua opinião, quais foram as consequências da atuação do G20 para processo de tomada de decisão no Sistema Multilateral de Comércio?

\section{Referências Bibliográficas}

\section{MEIO IMPRESSO}


AMORIM, CELSO. The WTO from the Perspective of a Developing Country. Fordham International Law Journal. Vol. 24, ${ }^{\circ} 1,2000$, p.95-106.

AREIAS, Ana Carolina. Os limites da Cooperação: O Brasil e o G-20 nas negociações agrícolas da Organização Mundial do Comércio. Rio de Janeiro, 2010. Dissertação de Mestrado - Instituto de Relações Internacionais, Pontifícia Universidade Católica do Rio de Janeiro.

CARVALHO, Maria Izabel Valladão de. Condicionantes Internacionais e Domésticos: O Brasil e o -20 nas Negociações Agrícolas da Rodada Doha. Revista de Ciências Sociais, Rio de Janeiro, Vol. 53, n², 2010, p.405-445.

CAPLOW, Theodore. A Theory of Coalitions in the Triad. American Sociological Review, Vol. 21, no 4, Ago. 1956, p. 489-493.

CLAPP, Jennifer. WTO Agriculture Negotiations: Implications for the Global South. Third World Quartely, Vol. 27, nº4, 2006. p. 563-577.

CEDRO, Rafael Rosa. Desenvolvimento Rural e a OMC: a experiência do Brasil. Curitiba: Juruá, 2011.

CONGRESSIONAL RESEARCH SERVICE (CRS). Agriculture: A Glossary of Terms, Programs and Laws. Report for Congress , 2005 Disponível em https://opencrs.com Acesso em 06/05/2012.

DÂMICO, Flavio S. O G-20 e as negociações agrícolas da OMC. Pontes, Vol. 3, nº3, 2007. Disponível em http://ictsd.org/i/news/12473/ Acesso em 20/06/2012.

DION, Léon. The Concept of Political Leadership: An Analysis. Canadian Journal of Political Science, Vol.1, nº1, Mar. 1968, p. 2-17.

DUPONT, Christophe (1994). "Coalition Theory: using power to build cooperation", in ZARTMAN, Willian (org.): International Multilateral Negotiation, parte II, cap. 7, p. 148177.

EDINGER, Lewis J., The Comparative Analysis of Political Leadership. Comparative Politics, Vol. 7, No2, 1975, p.253-269.

GAMSON, William A. A Theory of Coalition Formation. American Sociological Review, Vol. 26, no 3, Jun. 1961, p. 373-382.

GIORDANO DELGADO, Nelson; CAMPOLINA DE O. SOARES, Adriano. G20: Origem, Evolução, Significado e Perspectivas. Latin American Trade Network. Working Paper. Buenos Aires, Facultad Latinoamericana de Ciencias Sociales (FLACSO). nº89, fev. 2008. Disponivel em http://www.latn.org.ar/wp-content/uploads/2012/03/wp-89-Delgado-SoaresPortugues.pdf Acesso em 02/07/2012.

GOYOS JUNIOR; Durval de Noronha. A OMC e os Tratados da Rodada Uruguai. São Paulo: Observador Legal, 1994.

GRUBER, Lloyd. Ruling the World: Power Politics and the Rise of Supranational Institutions. Princeton, Princeton University Press, 2000.

HARDIN, Russel (1982), Collective Action. Baltimore, The John Hopkins University Press.

HIGGOTT, Richard A., COOPER, Andrew F. Middle Power Leadership and Coalition Building: Australia, the Cairns Group, and the Uruguay Round of Trade Negotiations. International Organization, Vol. 44, nº , 1990. p.589-632. 
HINCKLEY, Barbara. Twenty-one Variables Beyond the Size of Winning Coalitions. The Journal of Politics, Vol. 41, no 41, Fev. 1979, p. 192-212.

Hornbeck, J. F., COOPER, William H. Trade Promotion Authority (TPA) and the Role of Congress in Trade Policy. Congressional Research Service, 7/04/2011. Disponível em http://www.fas.org/sgp/crs/misc/RL33743.pdf Acesso em 24/06/2012

HUGUENEY FILHO, C. The G20: Passing Phenomenon or here to stay? Focus on Trade. Bangkok, Focus on the Global South, $\mathrm{n}^{\circ}$ 98, abril 2004. Disponível em http://focusweb.org/publications/FOT\%20pdf/fot98.pdf Acesso em 20/05/2012.

JALES, Mario; JANK, Marcos. On Product, Box and Blame Shifting: Negotiating Frameworks for Agriculture in the WTO Doha Round. Integration and Trade, Vol. 9, $\mathrm{n}^{\circ} 22$, 2005, p. 57-95.

MINISTÉRIO DAS RELAÇÕES EXTERIORES. G-20 e a OMC: Comunicados e Documentos. Brasília, DF. Fundação Alexandre de Gusmão, 2007.

MISSÃO DO BRASIL EM GENEBRA, Carta de Genebra. Ministério das Relações Exteriores. Ano 2, No. 1, Janeiro de 2003.

MISSÃO DO BRASIL EM GENEBRA, Carta de Genebra. Ministério das Relações Exteriores. Ano 2, No. 2, Fevereiro de 2003.

MISSÃO DO BRASIL EM GENEBRA, Carta de Genebra. Ministério das Relações Exteriores. Ano 2, No. 3, Março de 2003.

MISSÃO DO BRASIL EM GENEBRA, Carta de Genebra. Ministério das Relações Exteriores. Ano 2, No. 4, Abril de 2003.

MISSÃO DO BRASIL EM GENEBRA, Carta de Genebra. Ministério das Relações Exteriores. Ano 2, No. 5, Maio/ Junho de 2003.

MISSÃO DO BRASIL EM GENEBRA, Carta de Genebra. Ministério das Relações Exteriores. Ano 2, No. 6, de Setembro 2003.

MISSÃO DO BRASIL EM GENEBRA, Carta de Genebra. Ministério das Relações Exteriores. Ano 2, No. 7, Outubro de 2003.

MISSÃO DO BRASIL EM GENEBRA, Carta de Genebra. Ministério das Relações Exteriores. Ano 3, No. 1, Janeiro de 2004.

MISSÃO DO BRASIL EM GENEBRA, Carta de Genebra. Ministério das Relações Exteriores. Ano 3, No. 2, Abril de 2004.

MISSÃO DO BRASIL EM GENEBRA, Carta de Genebra. Ministério das Relações Exteriores. Ano 3, No. 3, Junho de 2004.

MISSÃO DO BRASIL EM GENEBRA, Carta de Genebra. Ministério das Relações Exteriores. Ano 3, No. 4, Julho de 2004.

MISSÃO DO BRASIL EM GENEBRA, Carta de Genebra. Ministério das Relações Exteriores. Ano 3, No. 5, Setembro de 2004.

MISSÃO DO BRASIL EM GENEBRA, Carta de Genebra. Ministério das Relações Exteriores. Ano 3, No. 6, Outubro de 2004.

MISSÃO DO BRASIL EM GENEBRA, Carta de Genebra. Ministério das Relações Exteriores. Ano 3, No. 7, Novembro/Dezembro de 2004. 
MISSÃO DO BRASIL EM GENEBRA, Carta de Genebra. Ministério das Relações Exteriores. Ano 4, n. ${ }^{\circ}$ 1, fevereiro de 2005.

MISSÃO DO BRASIL EM GENEBRA, Carta de Genebra. Ministério das Relações Exteriores. Ano 4, n. ${ }^{\circ}$ 2, abril de 2005.

MISSÃO DO BRASIL EM GENEBRA, Carta de Genebra. Ministério das Relações Exteriores. Ano 4, n. ${ }^{\circ}$ 3, junho de 2005.

MISSÃO DO BRASIL EM GENEBRA, Carta de Genebra. Ministério das Relações Exteriores. Ano 4, n. ${ }^{\circ}$, julho de 2005.

MISSÃO DO BRASIL EM GENEBRA, Carta de Genebra. Ministério das Relações Exteriores. Ano 4, n. ${ }^{\circ}$ 5, julho de 2005.

MISSÃO DO BRASIL EM GENEBRA, Carta de Genebra. Ministério das Relações Exteriores. Ano 4, n. ${ }^{\circ}$ 6, setembro de 2005.

MISSÃO DO BRASIL EM GENEBRA, Carta de Genebra. Ministério das Relações Exteriores. Ano 4, n. ${ }^{\circ}$, outubro de 2005.

MISSÃO DO BRASIL EM GENEBRA, Carta de Genebra. Ministério das Relações Exteriores. Ano 4, n. ${ }^{\circ}$ 8, Dezembro de 2005.

MISSÃO DO BRASIL EM GENEBRA, Carta de Genebra. Ministério das Relações Exteriores. Ano V, n. ${ }^{\circ}$, março de 2006.

MISSÃO DO BRASIL EM GENEBRA, Carta de Genebra. Ministério das Relações Exteriores. Ano V, n. ${ }^{\circ}$ 2, abril de 2006.

MISSÃO DO BRASIL EM GENEBRA, Carta de Genebra. Ministério das Relações Exteriores. Ano V, n. ${ }^{\circ}$ 3, maio de 2006.

MISSÃO DO BRASIL EM GENEBRA, Carta de Genebra. Ministério das Relações Exteriores. Ano V, n. ${ }^{\circ}$, junho de 2006.

MISSÃO DO BRASIL EM GENEBRA, Carta de Genebra. Ministério das Relações Exteriores. Ano V, n. ${ }^{\circ}$ 5, julho de 2006.

MISSÃO DO BRASIL EM GENEBRA, Carta de Genebra. Ministério das Relações Exteriores. Ano VI n. ${ }^{\circ}$ 1, março de 2007.

MISSÃO DO BRASIL EM GENEBRA, Carta de Genebra. Ministério das Relações Exteriores. Ano VI n. ${ }^{\circ}$ 2, maio de 2007.

MISSÃO DO BRASIL EM GENEBRA, Carta de Genebra. Ministério das Relações Exteriores. Ano VI n. ${ }^{\circ}$ 3, julho de 2007.

MISSÃO DO BRASIL EM GENEBRA, Carta de Genebra. Ministério das Relações Exteriores. Ano VI n. ${ }^{\circ}$, outubro de 2007.

MISSÃO DO BRASIL EM GENEBRA, Carta de Genebra. Ministério das Relações Exteriores. Ano VI n. ${ }^{\circ}$ 5, Dezembro de 2007.

MISSÃO DO BRASIL EM GENEBRA, Carta de Genebra. Ministério das Relações Exteriores. Ano VI n. ${ }^{\circ}$ 6, Dezembro de 2007.

MISSÃO DO BRASIL EM GENEBRA, Carta de Genebra. Ministério das Relações Exteriores. Ano VII n. ${ }^{\circ} 1$ Fevereiro de 2008.

MISSÃO DO BRASIL EM GENEBRA, Carta de Genebra. Ministério das Relações Exteriores. Ano VII n. ${ }^{\circ} 2$ Março de 2008. 
MISSÃO DO BRASIL EM GENEBRA, Carta de Genebra. Ministério das Relações Exteriores. Ano VII n. ${ }^{\circ} 3$ Junho de 2008.

MISSÃO DO BRASIL EM GENEBRA, Carta de Genebra. Ministério das Relações Exteriores. Ano VII n. ${ }^{\circ} 4$ Junho de 2008.

MISSÃO DO BRASIL EM GENEBRA, Carta de Genebra. Ministério das Relações Exteriores. Ano VII n. ${ }^{\circ} 5$ Julho de 2008.

NARLIKAR, Amrita. International Trade and Developing Countries: bargaining coalitions in the GATT \& WTO. London: Routledge, 2003.

NARLIKAR, Amrita. International Trade and Developing Countries, p. 29 apud Colleen HAMILTON e John WHALLEY, Coalitions in the Uruguay Round, Weltwirtschaftliches Archiv., v. 125, n.3, p. 547-556, 1989.

NARLIKAR, Amrita; TUSSIE, Diana. "The G-20 at the Cancun Ministerial: Developing Countries and their evolving coalitions in the WTO". The World Economy, Oxford, vol. 27, $\mathrm{n}^{\mathrm{o}}$. 7, julho de 2004, p. 947-966.

NARLIKAR, Amrita; HURRELL, Andrew; A New politics of confrontation? Developing countries at Cancun and beyond. Global Society, v. 20, nº 4, 2006.

NARLIKAR, Amrita; WILKINSON, Rorden. Collapse at the WTO: A Cancun Post-Mortem. Third World Quarterly. Vol 25, n 3, 2004, p 447-460.

NARLIKAR, Amrita, A Theory of Bargaining Coalitions in the WTO. Em NARLIKAR, Amrita; VICKERS, Brendan (eds.). Leadership and Change in the Multilateral Trading System. Republic of Letters Publishing, 2009, p. 183-201.

NARLIKAR, Amrita; WOODS, Ngaire. International Trade and the Emergence of New Inter-State Coalitions. Latin-American Trade Network, Working Papers, 1999. Disponível emhttp://www.globaleconomicgovernance.org/wpcontent/uploads/International\%20Trade\%2 0and\%20the\%20Emergence.pdf. Acesso em 20/06/2012.

OLIVEIRA, Amâncio J., ONUKI, Janina e OLIVEIRA, Emmanuel. "Coalizões Sul-Sul e multilateralismo: Índia, Brasil e África do Sul". Contexto Internacional, vol. 28, $\mathrm{n}^{\circ} 2$, Dezembro 2006.

OLIVEIRA, Amâncio Jorge de; ONUKI, Janina: Coalizões Sul-Sul e as negociações multilaterais: os países intermediários e a coalizão IBSA. São Paulo: Mídia Alternativa Comunicação e Editora, 2007.

OLIVEIRA, Amâncio; Onuki Janina. Negociações Internacionais: Teoria e Técnicas. Em AYERBE, Luis Fernando; BOJIKIAN, Neusa (Orgs.), Negociações Econômicas Internacionais: Abordagens, atores e perspectivas desde o Brasil. São Paulo: Editora UNESP: Programa San Tiago Dantas de Pós Graduação, 2011.

OLSON, Mancur. (1999), A lógica da Ação Coletiva. Os Benefícios Públicos e uma Teoria dos Grupos Sociais. Tradução Fábio Fernandez. São Paulo, EDUSP

PÁDUA LIMA, Maria Lucia L. M. Brazil's Multilateral Trade Diplomacy in the WTO. Em NARLIKAR, Amrita; VICKERS, Brendan (eds.). Leadership and Change in the Multilateral Trading System. Republic of Letters Publishing, 2009, p. 75-95.

PRESSER, Mário Ferreira; MADUREIRA, Frederico Quaresma, LENK, Wolfgang. NEGOCIAÇÕES EM AGRICULTURA NA OMC. Revista Economia Política 
Internacional: Análise Estratégica. no 1 Julho/Setembro, 2004. Instituto de Economia UNICAMP. Disponível em: http://www.eco.unicamp.br/aspscripts/boletim_ceri/boletim/boletim1/editorial.pdf Acesso em 20/05/2012.

PUTNAM, Robert D. Diplomacy and Domestic Politics: The Logic of Two-Level Games. International Organization, Vol. 42, No. 3, 1988, p. 427-460.

RAMANZINI JÚNIOR, Haroldo; LIMA, Thiago. Diplomacia Comercial Agrícola: As posições do Brasil na Rodada Doha da OMC. Em AYERBE, Luis Fernando; BOJIKIAN, Neusa (Orgs.), Negociações Econômicas Internacionais: Abordagens, atores e perspectivas desde o Brasil. São Paulo: Editora UNESP: Programa San Tiago Dantas de Pós Graduação, 2011.

RAMANZINI JÚNIOR, Haroldo. A Política Externa Brasileira e Regimes Internacionais. O Brasil na OMC. Relatório final de Iniciação Científica. FAPESP, 2006.

RUSSETT, Bruce M. Components of an Operational Theory of International Alliance Formation. The Journal of Conflict Resolution. Vol. 12, nº 3, Set. 1968, p. 285-301.

SHEPSLE, Kenneth; BUENO DE MESQUITA, Bruce. Willian Harrison Riker (1920-1993) Biographical Memoirs, Washington D.C, EUA, The National Academy Press, 2001.

STEINBERG, Richard H. In the Shadow of Law or Power? Consensus-Based Bargaining and Outcomes in the GATT/WTO. International Organization, vol.56, no. 2, Spring 2002. Dezembro 2006, pp. 465-503.

RIKER, William H. The Theory of Political Coalitions. New Heaven, Yale University Press, 1962.

TALBERG, Jonas. Formal Leadership in Multilateral Negotiations: A Rational Institutionalist Theory. The Hague Journal of Diplomacy. Estocolmo, 2006.

THORSTENSEN, Vera. OMC: As regras do comércio internacional e a Nova Rodada de Negociações Internacionais. São Paulo: Aduaneiras, 2001.

THORSTENSEN, Vera; JANK, Marcos S (coord.). O Brasil e os grandes temas do comércio internacional. São Paulo, Lex Editora; Aduaneiras, 2005.

UNDERDAL, Arild (1994). "Leadership Theory: Rediscovering the arts of management", in WILLIAN ZARTMAN (org.): International Multilateral Negotiation, cap. 8, p. 178-197.

WORLD TRADE ORGANIZATION (WTO). Agreement on Agriculture. In: The Legal Texts: The Results of the Uruguay Round of Multilateral Trade Negotiation. Cambridge, Reino Unido, Cambridge University Press, 2010.

WORLD TRADE ORGANIZATION (WTO). General Agreement on Tariffs and Trade (GATT 1947). The Legal Texts: The Results of the Uruguay Round of Multilateral Trade Negotiation. Cambridge, Reino Unido, Cambridge University Press, 2010.

WORLD TRADE ORGANIZATION. Grupo de Negociação em Acesso a Mercados. Modalities for the Establishment of Specific Binding Commitments under the Reform Programme, 1993. (MTN.GNG/MA/W/24).

WORLD TRADE ORGANIZATION. Sessão Especial do Comitê de Agricultura. Domestic Support. Background Paper by the Secretariat, 2000. G/AG/NG/S/1

WORLD TRADE ORGANIZATION. Sessão Especial do Comitê de Agricultura. Members' usage of domestic support categories export subsidies and export credits. Background Paper by the Secretariat, 2000. G/AG/NG/S/12. 
WORLD TRADE ORGANIZATION (WTO). Sessão Especial do Comitê de Agricultura. Domestic Support - Background Paper by the Secretariat. 13/04/2000. G/AG/NG/S/1.

WORLD TRADE ORGANIZATION (WTO). Declaração Ministerial. Conferência Ministerial, 4 $4^{\mathrm{a}}$ Sessão, 20/11/2001. WT/MIN(01)/DEC/1.

WORLD TRADE ORGANIZATION (WTO). The WTO Agreements Series: Agriculture. Genebra, Suiça, 2003.

WORLD TRADE ORGANIZATION (WTO). Documento Conjunto CE-EUA em Agricultura 13/08/2003. JOB(03)/157. Em MISSÃO DO BRASIL EM GENEBRA, Carta de Genebra. Ministério das Relações Exteriores. Ano 2, No. 6, de Setembro 2003, p.3-4.

WORLD TRADE ORGANIZATION (WTO). Documento do G20 em Agricultura 20/08/2003. JOB(03)/162. Em MISSÃO DO BRASIL EM GENEBRA, Carta de Genebra. Ministério das Relações Exteriores. Ano 2, No. 6, de Setembro 2003, p.6-8..

WORLD TRADE ORGANIZATION (WTO). Doha Work Programme. 02/08/2004. WT/L/579.

WORLD TRADE ORGANIZATION (WTO). Declaração Ministerial. Conferência

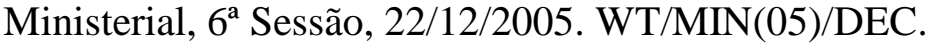

WORLD TRADE ORGANIZATION (WTO). Sessão Especial do Comitê de Agricultura. Revised Draft Modalities for Agriculture. 06/12/2008. TN/AG/W/4/Rev.4

WEALE, Albert. Social Choice versus Populism? An interpretation of Riker's Political Theory. British Journal of Political Science, Cambridge, Reino Unido, Cambridge University Press Vol. 14, nº 3, 1984, p. 369-385.

YOUNG, Oran R. Political Leadership and Regime Formation: On the development of Institutions in International Society. International Organization, Vol.45, nº 3, 1991, p.281308.

\section{Meio ELETRônico}

Centro de Estudos Avançados em Economia Aplicada - Esalq/USP: http://www.cepea.esalq.usp.br/

Fundação Centro de Estudos do Comércio Exterior (FUNCEX): http://www.funcex.org.br/

G-20: http://www.g-20.mre.gov.br

Instituto Brasileiro de Geografia e Estatística (IBGE): www.ibge.gov.br

Instituto de Estudo do Comércio e Negociações Internacionais: http//www.iconebrasil.org.br

International Centre for Trade and Sustainable Development: http://www.ictsd.org/

Ministério do Desenvolvimento Indústria e Comércio (MDIC): www.mdic.gov.br

Ministério do Desenvolvimento Agrário (MDA): www.mda.gov.br

Ministério da Agricultura, Pecuária e Abastecimento (MAPA): www.mapa.gov.br

WTO: www.wto.org 
WTO: World Tariff Profile 2010, p. 24-25. Disponível em http://www.wto.org/english/res_e/booksp_e/tariff_profiles10_e.pdf. Acesso em 07/05/2012.

WTO: Groups in the WTO, 2012. Disponível em http://www.wto.org/english/tratop_e/dda_e/negotiating_groups_e.pdf Acesso em 04/06/2012. 